\title{
PENGARUH ARUS KAS OPERASI DAN MANAJEMEN ASET TERHADAP KEMAMPULABAAN, PERTUMBUHAN PERUSAHAAN
}

Studi Kasus Pada PT. Indocement Tunggal Prakarsa, Tbk dan PT. Semen Gresik (Persero), Tbk

SKRIPSI

Oleh :

LINA ULORLO

NRP : 07110096

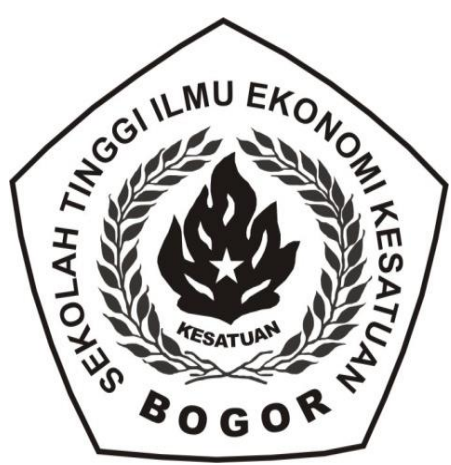

PROGRAM STUDI MANAJEMEN KEUANGAN SEKOLAH TINGGI ILMU EKONOMI KESATUAN BOGOR 2012 


\title{
PENGARUH ARUS KAS OPERASI DAN MANAJEMEN ASET TERHADAP KEMAMPULABAAN, PERTUMBUHAN PERUSAHAAN
}

Studi Kasus Pada PT. Indocement Tunggal Prakarsa, Tbk dan PT. Semen Gresik (Persero), Tbk

\author{
SKRIPSI \\ Sebagai salah satu syarat untuk memperoleh \\ gelar Sarjana pada Program Studi Manajemen Keuangan \\ Sekolah Tinggi IImu Ekonomi Kesatuan
}

Oleh :

LINA ULORLO

NRP : 07110096

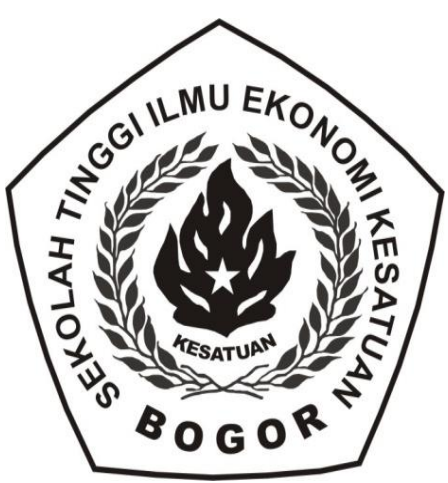

PROGRAM STUDI MANAJEMEN KEUANGAN

SEKOLAH TINGGI ILMU EKONOMI KESATUAN BOGOR 


\section{PENGARUH ARUS KAS OPERASI DAN MANAJEMEN ASET TERHADAP KEMAMPULABAAN, PERTUMBUHAN PERUSAHAAN}

Studi Kasus Pada PT. Indocement Tunggal Prakarsa, Tbk dan PT. Semen Gresik (Persero), Tbk

SKRIPSI

Telah disetujui Sekolah Tinggi Ilmu Ekonomi Kesatuan pada, Hari

Tanggal

Mengetahui

Ketua STIE Kesatuan

Ketua Jurusan Manajemen STIE Kesatuan

Dr. Bambang Pamungkas, Ak., MBA

Yoyon Supriadi, SE., MM 


\section{PENGARUH ARUS KAS OPERASI DAN MANAJEMEN ASET TERHADAP KEMAMPULABAAN DAN PERTUMBUHAN PERUSAHAAN}

Studi Kasus Pada PT. Indocement Tunggal Prakarsa, Tbk dan PT. Semen Gresik (Persero), Tbk

SKRIPSI

Telah disetujui oleh Pembimbing

Aan Soelehan SE,. MM

Bogor,

Penguji I

Penguji II 


\begin{abstract}
Lina Ulorlo. NRP: 07110096. Influence of Cash Flow and Assets Management From Operational Increasment Profitability and Growth of the Company. Case Study at PT. Indocement Tunggal Prakarsa, Tbk and PT. Semen Gresik (Persero) Tbk. Under the guidance of Mr. Aan Soelehan SE., MM.
\end{abstract}

Cash flow from operational is cash from operations, where the presence of operating cash flow the company can decide to use existing funds for its operations and operating cash flows to the attention of the management company because it is useful for decision making.

Cash flow rom operational increased profitability is expected to increase due to the increase in operating cash flow $f$ the company can decide that there are funds for its operations but must be accompanied by efficiency in operating expenses and cost of good sales. With the increase in operating cash flow is expected also to increase the company's growth in terms of sales due to increased operating cash flow the company can increase production capacity to increase sales.

In this study the authors use a formula to operating cash flow $(X)$ is operating cash flow to sales, is the formula for profitability while operating margin for the company's growth is sales - sales $_{t-1}$ to salest. Moreover, the authors use a common size analysis of common size horizontal and common size vertical.

From the results of regression testing at PT. Indocement, Page got the significance of $0 \%$ of operating cash flow to operating income which indicates that operating cash flow has influence with $10 \%$ significance level. Results of regression test between operating cash flows of the company's growth got result of significance of $44.8 \%$ which indicates that operating cash flow has no influence on growth companies with a significance level of $10 \%$ this was due to cash generated from operating cash flow is used to make payments their liability.

From the results of regression testing against PT. Semen Gresik (Persero) Tbk significance of the results obtained at $0 \%$ of operating cash flow to operating income of the shows that operating cash flow has influence with $10 \%$ significance level. Results of regression test between operating cash flows of the company's growth got result of significance of 95.1\% which indicates that operating cash flow has no influence on growth companies with a significance level of $10 \%$ this was due to cash generated from operating activities is mainly invested into cash and cash equivalents. 
Keywords: Cash Flow from Operational, Assets Management, Profitability, Growth

\begin{abstract}
ABSTRAK
Lina Ulorlo. NRP : 07110096. Pengaruh Arus Kas Operasi dan Manajemen Aset Terhadap Kemampulabaan dan Pertumbuhan Perusahaan. Studi Kasus Pada PT. Indocement Tunggal Prakarsa, Tbk dan PT. Semen Gresik (Persero), Tbk. Dibawah bimbingan Bapak Aan Soelehan SE., MM.

Arus kas operasi merupakan kas yang berasal dari kegiatan operasional perusahaan, dimana dengan adanya arus kas operasi perusahaan dapat memutuskan untuk menggunakan dana yang ada untuk kegiatan operasionalnya dan arus kas operasi menjadi perhatian para manajemen perusahaan karena berguna untuk pengambilan keputusan.

Arus kas operasi yang mengalami peningkatan diharapkan dapat meningkatkan kemampulabaan karena dengan peningkatan arus kas operasi perusahaan dapat memutuskan dana yang ada untuk kegiatan operasionalnya tetapi harus diiringi dengan efisiensi pada beban usaha dan beban pokok penjualan. Dengan meningkatnya arus kas operasi diharapkan juga dapat meningkatkan pertumbuhan perusahaan dari segi penjualan karena dengan meningkatnya arus kas operasi perusahaan dapat meningkatkan kapasitas produksi yang dapat meningkatkan penjualan.

Dalam penelitian ini penulis menggunakan rumus untuk arus kas operasi $(X)$ adalah arus kas operasi terhadap penjualan, rumus untuk kemampulabaan adalah marjin laba usaha sedangkan untuk pertumbuhan perusahaan adalah penjualan ${ }_{t}-$ penjualan $_{t-1}$ terhadap penjualan $_{t-1}$. Selain itu penulis menggunakan analisis common size yaitu common size horizontal dan common size vertikal.

Dari hasil pengujian regresi terhadap PT. Indocement Tunggal Prakarsa, Tbk didapatkan hasil signifikansi sebesar 0\% antara arus kas operasi terhadap laba operasi yang menunjukkan bahwa arus kas operasi mempunyai pengaruh dengan tingkat signifikansi $10 \%$. Hasil uji regresi antara arus kas operasi terhadap pertumbuhan perusahaan didapatkan hasil signifikansi sebesar 44,8\% yang menunjukkan bahwa arus kas operasi tidak mempunyai pengaruh terhadap pertumbuhan perusahaan dengan tingkat signifikansi $10 \%$ hal ini disebabkan karena kas yang dihasilkan dari arus kas operasi digunakan untuk melakukan pembayaran kewajibannya.

Dari hasil pengujian regresi terhadap PT. Semen Gresik (Persero), Tbk didapatkan hasil signifikansi sebesar 0\% antara arus kas operasi terhadap laba operasi yang menunjukkan bahwa arus kas operasi
\end{abstract}


mempunyai pengaruh dengan tingkat signifikansi $10 \%$. Hasil uji regresi antara arus kas operasi terhadap pertumbuhan perusahaan didapatkan hasil signifikansi sebesar 95,1\% yang menunjukkan bahwa arus kas operasi tidak mempunyai pengaruh terhadap pertumbuhan perusahaan dengan tingkat signifikansi $10 \%$ hal ini disebabkan karena kas yang dihasilkan dari aktivitas operasi diinvestasikan sebagian besar kedalam kas dan setara kas.

Katakunci : Arus Kas Operasi, Manajemen Aset, Kemampulabaan, Pertumbuhan Perusahaan 


\section{KATA PENGANTAR}

Dengan mengucapkan puji dan syukur kehadirat Allah SWT karena hanya dengan rahmat dan karunia - Nya lah penulis dapat menyelesaikan skripsi yang berjudul “ Pengaruh Arus Kas Operasi Terhadap Peningkatan Kemampulabaan Dan Pertumbuhan Perusahaan”. Tujuan penulisan ini adalah untuk memenuhi salah satu syarat untuk memperoleh gelar Sarjana Ekonomi Jurusan Manajemen Keuangan pada Sekolah Tinggi Ilmu Ekonomi Kesatuan.

Pada kesempatan kali ini dengan segala kerendahan hati penulis berharap, semoga skripsi ini dapat memberikan manfaat dan wawasan serta gambaran yang nyata mengenai arus kas operasi, kemampulabaan dan pertumbuhan perusahaan.

Dalam penulisan skripsi ini penulis menyadari adanya kekurangan baik dalam segi materi maupun sistimatika yang masih jauh dari sempurna dan tidak luput dari bantuan beberapa pihak yang telah bersedia memberikan pendapatnya, dorongan serta doa. Dan semua itu sangat berarti bagi penulis. Maka dari itu segala kritik dan saran dari semua pihak yang sifatnya membangun akan penulis terima dengan senang hati untuk kesempurnaan dalam penulisan skripsi ini.

Maka pada kesempatan kali ini penulis ingin mengucapkan terima kasih serta penghargaan yang setinggi - tingginya kepada :

1. Bapak Bambang Pamungkas, Ak., MBA selaku Ketua Sekolah Tinggi IImu Ekonomi Kesatuan. 
2. Bapak Yoyon Supriadi, SE., MM selaku Ketua Jurusan Manajemen.

3. Bapak Aan Soelehan, SE., MM selaku dosen pembimbing yang selalu memberikan pengarahan didalam penulisan skripsi ini.

4. Bapak Sujana, SE., MM yang telah membantu penulis didalam penyelesaian skripsi terutama untuk pengarahan SPSS.

5. Papaku yang selau memberikan dorongan baik berupa materi maupun imateril. Tanpa kerja keras dari mama ku penulis tidak akan sampai pernah pada saat sekarang ini.

6. Buat teman ku Reza yang telah memberikan dorongan hingga sampai sekarang ini.

7. Pampam, Lia, Ferdy dan Julianus yang telah berjasa kepada penulis didalam penyelesaian skripsi ini.

8. Teman - Temanku Indra, Meta, Siti dan semuanya yang tidak bisa penulis sebutkan satu persatu yang selama ini telah bersama - sama dan untuk teman - temanku di kelas MK Karyawan dan MK Sore terima kasih untuk selama ini.

9. Buat seseorang yang selama ini telah menemani penulis memberikan warna dihidupku.

10. Seluruh staff dan karyawan STIE Kesatuan yang tidak dapat penulis sebutkan satu persatu.

Akhir kata semoga kebaikan dan jerih payah yang telah dilakukan mendapatkan imbalan yang setimpal dari Allah SWT 


\section{DAFTAR ISI}

\section{Halaman}

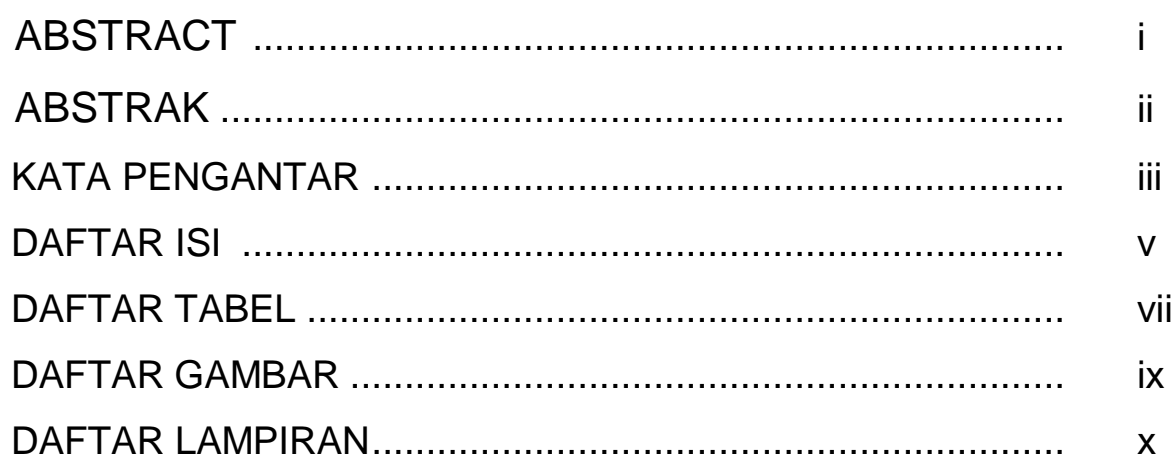

BAB I PENDAHULUAN ......................................................... 1

1.1. Latar Belakang penelitian ............................................. 1

1.2. Identifikasi Masalah ....................................................... 4

1.3. Maksud dan Tujuan Penelitian ........................................ 4

1.4. Kegunaan Penelitian ................................................. 5

BAB II TINJAUAN PUSTAKA .................................................. 7

2.1 Kerangka Pemikiran Teoritis.......................................... 7

2.1.1 Manajemen Keuangan ....................................... 7

2.1.1.1. Pengertian Manajemen Keuangan .............. 7

2.1.1.2. Tujuan Manajemen Keuangan...................... 10

2.1.2. Pengertian Kas ................................................. 10

2.1.3. Pengertian Arus Kas............................................ 11

2.1.4 Laporan Arus Kas .......................................... 16

2.1.4.1 Pengertian Laporan Arus Kas..................... 16

2.1.4.2 Tujuan Laporan Arus Kas.......................... 20

2.1.4.3 Manfaat Arus Kas.................................... 22

2.1.4.4 Macam - Macam Arus Kas ....................... 23

2.1.4.5 Klasifikasi Arus Kas ................................... 24

2.1.4.6 Arus Kas Operasi ....................................... 25

2.1.4.7 Peranan Arus Kas Operasi .......................... 26

2.1.4.8 Metode Laporan Arus Kas ......................... 27

2.1.4.9 Analisis Laporan Arus Kas.......................... $\quad 31$

2.1.5 Manajemen Aset ........................................... 33 
2.1.5.1 Pengertian Manajemen Aset ....................... 33

2.1.5.2 Macam-macam Activa ............................... 34

2.1.5.3 Manajemen Kas ...................................... 36

2.1.6 Kemampulabaan ............................................ 39

2.1.6.1 Pengertian Kemampulabaan ....................... 39

2.1.6.2 Hal - Hal Yang Mempengaruhi

Kemampulabaan....................................... 41

2.1.6.3 Jenis - Jenis Kemampulabaan ..................... 42

2.1.6.4 Peranan Kemampulabaan ............................ 44

2.1.6.5 Ukuran Kemampulabaan .............................. 45

2.1.7 Pertumbuhan Perusahaan..................................... 49

2.2 Kerangka Pemikiran Konseptual ................................... 51

2.3 Premis dan Hipotesis .................................................... 54

2.3.1 Premis ............................................................ 54

2.3.2 Hipotesis ..................................................... 55

2.3.2.1 Hipotesis Penelitian .......................................... 55

2.3.2.2 Hipotesis Statistik .............................................. $\quad 55$

BAB III METODOLOGI PENELITIAN ........................................ 57

3.1 Sejarah Perusahaan..................................................... 57

3.1.1 PT. Indocement Tunggal Prakarsa ........................ 57

3.1.2 PT. Semen Gresik (Persero), Tbk.......................... 64

3.2. Uraian Tugas.......................................................... 67

3.2.1 PT. Indocement Tunggal Prakarsa, Tbk ................. 67

3.2.2 PT. Semen Gresik (Persero), Tbk........................... 68

3.3 Lokasi Dan Waktu Penelitian............................................ 68

3.4 Metode Penelitian ...................................................... 69

3.5 Operasionalisasi Variabel .......................................... 70

3.6 Jenis Dan Sumber Penelitian ...................................... 71

3.7 Prosedur Pengumpulan Data ..................................... 72

3.8 Metode Analisis ...................................................... 73

BAB IV HASIL DAN PEMBAHASAN.......................................... 78

4.1 Arus Kas Operasi, Total Asset Turnover, Net Profit Margin dan

Pertumbuhan Perusahaan................................................ $\quad 78$

4.1.1 Arus Kas Operasi PT Indocement .......................... 78 
4.1.2 Total Asset Turnover PT Indocement ..................... 81

4.1.3 Net Profit Margin PT Indocement........................... 87

4.1.4 Pertumbuhan Perusahaan PT Indocement............... 89

4.1.5 Arus Kas Operasi PT Semen Gresik ..................... $\quad 90$

4.1.6 Total Asset Turnover PT Semen Gresik ................. 93

4.1.7 Net Profit Margin PT Semen Gresik....................... 96

4.1.8 Pertumbuhan Perusahaan PT Semen Gresik ............ 101

4.2 Pengaruh Arus Kas Operasi dan Total Asset Turnover

Terhadap Net Profit Margin dan Pertumbuhan Perusahaan

PT Indocement ......................................................... 107

4.2.1 Pengaruh Arus Kas Operasi dan TATO Terhadap Net Profit

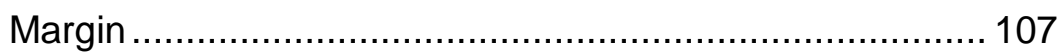

4.2.2 Pengaruh Arus Kas Operasi dan TATO Terhadap Pertumbuhan Perusahaan ....................................... 110

4.3 Analisis Perbandingan Pengelolaan Arus Kas Operasi, Manajemen Aset, Kemampulabaan, Pertumbuhan Perusahaan Pada PT Semen Gresik (Persero) Tbk dan PT Indocement Tunggal Prakarsa, Tbk

BAB V SIMPULAN DAN SARAN .............................................. 118

5.1 Simpulan ............................................................. 118

5.2 Saran ................................................................ 119

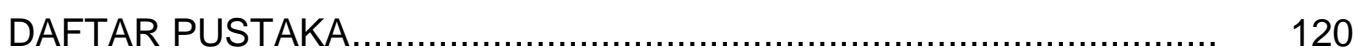

LAMPIRAN ............................................................................ 121 


\section{DAFTAR TABEL}

Nomor

Teks

Halaman

2.1 Faktor-faktor yang mempengaruhi penerimaan dan pengeluaran kas 19

3.1 Uraian Tugas PT. Indocement Tunggal Prakarsa, Tbk ............... 67

3.2 Uraian Tugas PT. Semen Gresik (Persero), Tbk..................... 68

3.3 Operasionalisasi Variabel ................................................. 71

3.4 Keputusan Auto Korelasi .................................................... 78

4.1 Arus Kas Operasi dan Penjualan PT Indocement Tunggal Prakarsa, Tbk 79

4.2 Total Asset dan Penjualan PT. Indocement Tunggal Prakarsa, Tbk 81

4.3 Penjualan dan Laba Bersih PT Indocement Tunggal Prakarsa, Tbk 85

4.4 Net Profit dan Penjualan PT Indocement Tunggal Prakarsa, Tbk 87

4.5 Pertumbuhan Perusahaan PT Indocement Tunggal Prakarsa,Tbk 89

4.6 Arus Kas Operasi dan Penjualan PT Semen Gresik (Persero) Tbk 91

4.7 Total Asset dan Penjualan PT Semen Gresik (Persero) Tbk ....... 93

4.8 Penjualan dan Net Profit PT Semen Gresik (Persero) Tbk ......... 97

4.9 Net Profit Margin PT Semen Gresik (Persero) Tbk .................... 100

4.10 Pertumbuhan Perusahaan PT Semen Gresik (Persero), Tbk ...... 101

4.11 Koefisien Korelasi terhadap Net Profit Margin PT Semen Gresik

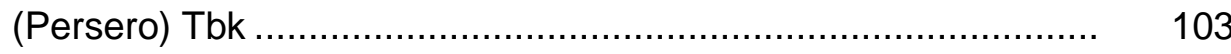

4.12 Anova terhadap Net Profit Margin PT Semen Gresik (Persero) Tbk 104

4.13 Koefisien Korelasi terhadap Pertumbuhan Perusahaan PT Semen Gresik (Persero) Tbk .......................................................... 105

4.14 Anova terhadap Net Profit Margin PT Semen Gresik (Persero) Tbk 106

4.15 Koefisien Korelasi terhadap Net Profit Margin PT Indocement .... 107

4.16 Anova terhadap Net Profit Margin PT Indocement .................... 109

4.17 Koefisien Korelasi terhadap pertumbuhan perusahaan PT Indocement

4.18 Anova terhadap pertumbuhan perusahaan PT Indocement ...... 111

4.19 Tabel arus kas operasi PT Semen Gresik dan PT Indocement.... 113

4.20 Tabel TATO PT Semen Gresik dan PT Indocement................... 114

4.21 Tabel NPM PT Semen Gresik dan PT Indocement.................... 116 
4.22 Tabel pertumbuhan perusahaan PT Semen Gresik dan

PT Indocement 


\section{DAFTAR GAMBAR}

Nomor

Teks

Halaman

2.1. Kerangka Konseptual ....................................................... 53

4.1. Grafik Arus Kas Operasi PT. Indocement Tunggal Prakarsa Tbk . 80

4.2. Grafik Total Aset Turnover PT. Indocement Tunggal Prakarsa Tbk 83

4.3. Grafik Net Profit Margin PT. Indocement Tunggal Prakarsa Tbk ... 88

4.4. Grafik Pertumbuhan PT Indocement Tunggal Prakarsa Tbk ........ 90

4.5 Grafik Arus Kas Operasi PT. Semen Gresik (Persero) Tbk .......... 92

4.6. Grafik Total Aset Turnover PT. Semen Gresik (Persero) Tbk....... 95

4.7. Grafik Net Profit Margin PT. Semen Gresik (Persero) Tbk ............ 100

4.8. Grafik Pertumbuhan Perusahaan PT. Semen Gresik (Persero) Tbk 102

4.9. Grafik Pergerakan Arus Kas Operasi PT Semen Gresik (Persero) dan PT Indocement Tunggal Prakarsa Tbk

4.10 Grafik Pergeraka TATO PT Semen Gresik (Persero) dan

PT Indocement Tunggal Prakarsa Tbk

4.11 Grafik Net Profit Margin PT. Indocement Tunggal

Prakarsa, Tbk

4.12 Grafik Pergerakan Pertumbuhan Perusahaan PT Semen Gresik (Persero) dan PT Indocement Tunggal Prakarsa Tbk 


\section{BAB I \\ PENDAHULUAN}

\subsection{Latar Belakang Penelitian}

Perusahaan (Enterprise) yaitu suatu lembaga yang diorganisasikan dan dijalankan untuk menyediakan barang atau jasa bagi masyarakat dengan motif atau insentif keuntungan, perusahaan terdiri dari satu atau lebih unit - unit usaha yang disebut pabrik. Perusahaan selain sebagai suatu lembaga yang merupakan suatu wadah yang diorganisasikan, dididirikan, dan diterima dalam tata kehidupan masyarakat. Tujuan setiap perusahaan adalah memperoleh laba (net profit). Laba merupakan salah satu alat ukur bagi suatu perusahaan untuk dapat bertahan dan melanjutkan operasinya atau sebaliknya harus berhenti beroperasi dan menutup perusahaannya.

Didalam tercapainya tujuan perusahaan manajemen melakukan berbagai cara yang sesuai dengan prosedur yang sudah ditetapkan oleh perusahaan. Perusahaan yang melakukan pengontrolan terhadap apa yang dilakukan oleh pihak manajemen perusahaan didalam menghasilkan laba dari kegiatan produksinya diharapkan dapat memperoleh hasil yang maksimal dan dapat meningkatkan kinerja manajemen dengan tercapainya apa yang diharapkan oleh perusahaan seperti meningkatnya proses produksi yang diharapkan dengan meningkatnya proses produksi dapat meningkatkan penjualan dan akhirnya labapun bisa diraih dengan hasil yang lebih besar.

Perusahaan juga harus siap menghadapi tantangan dari luar seperti munculnya pesaing - pesaing baru, munculnya inovasi - inovasi terhadap produk masyarakat, dan mutu produk yang akan ditawarkan kepada konsumen oleh produsen lainnya, oleh karena itu perusahaan harus dapat mempertahankan 
konsumennya agar tetap setia pada produknya dengan mengembangkan inovasi - inovasi terhadap produknya dan menjaga kualitas produknya.

Sekarang ini selain tantangan dari dunia usaha yang semakin dinamis tetapi juga pertumbuhan ekonomi yang tidak stabil mengharuskan perusahaan mampu bertahan dan bersaing di dalam keadaan seperti ini. Perusahaan harus memiliki dana kas yang cukup untuk dapat memenuhi kegiatan operasionalnya dan dapat melindungi perusahaan dari keadaan yang tak terduga sebelumnya. Dalam hal ini kas berperan untuk kelancaran kegiatan perusahaan, oleh karena itu untuk memdukung proses kelancaran produksinya kas harus direncanakan dan diawasi, baik penerimaan (sumber - sumber) maupun pengeluaran (penggunaan). Hal utama yang perlu dipahami di dalam mengatur kas adalah memahami fungsi dana tersebut yang kita miliki. Apakah akan digunakan semuanya atau sebagian akan ada yang diinvestasikan ataupun disimpan. Jika dalam penyimpannya dana tersebut dibutuhkan untuk jangka waktu yang relatif pendek, maka simpan atau invesatasikan dana tersebut kedalan investasi yang dapat dicairkan dengan mudah dan cepat seperti di deposito.

Didalam perusahaan tidak terlepas dari arus kas, karena didalam arus kas dapat terlihat kemana saja uang digunakan dan dari mana saja uang diterima. Arus kas terdapat 3 jenis, yaitu arus kas dari aktivitas operasi, arus kas dari aktivitas investasi, dan arus kas dari aktivitas pendanaan. Dimana arus kas operasi merupakan refleksi kemampuan manajemen dalam menciptakan dana kas melalui pengelolaan sumber daya perusahaan,arus kas investasi merupakan refleksi aktivitas investasi yang mempengaruhi arus kas perusahaan, sedangkan arus kas pendanaan merupakan refleksi pendanaan yang mempengaruhi arus kas secara keseluruhan.

Arus kas dari aktivitas operasi sering menjadi perhatian manajemen dalam pengelolaan keuangannya, karena arus kas investasi dan arus kas 
pendanaan ada untuk mendukung proses produksi perusahaan yang sudah menjadi kegiatan utamanya. Arus kas dari aktivitas operasi sering digunakan oleh pihak intern untuk mengetahui kemana saja dana kas digunakan dan darimana sja dana kas diperoleh, pihak eksternal (pemegang saham) menggunakan arus kas dari aktivitas operasi sebagai bahan untuk pengambilan keputusan. Dengan adanya dana kas yang tersedia perusahaan mampu menghasilkan barang produksi yang dapat menghasilkan laba. Dengan laba yang diperoleh oleh perusahaan, maka perusahaan diharapkan dapat tumbuh dan berkembang seperti yang diharapkan oleh pihak - pihak yang terlibat didalamnya, seperti pihak manajemen, pemegang saham ataupun pemilik perusahaan tersebut. Pertumbuhan perusahaan adalah hal yang diinginkan oleh perusahaan,karena dengan adanya pertumbuhan dapat dikatakan bahwa kinerja perusahaan tersebut baik.

Hubungan antara arus kas operasi terhadap kemampulabaan dan pertumbuhan perusahaan mempunyai keterkaitan. Arus kas operasi yang dihasilkan dapat menambahkan modal perusahaan untuk kegiatan operasional perusahaan berikutnya. Semakin tinggi hasil arus kas yang mampu dihasilkan oleh manajemen, maka semakin tinggi modal yang dimiliki oleh perusahaan dengan tambahan modal dari arus kas operasi. Dengan meningkatnya modal, maka kegiatan produksi dapat ditingkatkan dan diharapkan dengan meningaknya jumlah produksi penjualan pun meningkat. Dengan demikian laba yang akan diperoleh akan meningkat juga seiring dengan meningkatnya penjualan. Demikan halnya dengan pertumbuhan perusahaan, perusahaan dapat dikatakan tumbuh jika penjualan dari waktu ke waktu mengalami kenaikan. Kenaikan penjualan bisa disebabkan karena meningkatnya jumlah produksi yang dihasilkan. Meningkatnya jumlah produksi bisa dikarenakan adanya tambahan modal dari dana kas yang dihasilkn dari arus kas operasi. Dimana dana kas yang dihasilkan 
digunakan untuk tambahan modal untuk kegiatan operasional perusahaan berikutnya.

Berdasarkan latar belakang masalah diatas, maka penulis berminat untuk mengambil judul dalam penulisan skripsi ini adalah : "Pengaruh Arus Kas Operasi Dan Manajemen Aset Terhadap Kemampulabaan, Pertumbuhan Perusahaan".

\subsection{Identifikasi Masalah}

Dari latar belakang masalah yang penulis kemukakan diatas, maka penulis mengidentifikasikan permasalahan yang ada adalah :

1. Bagaimana pengaruh arus kas operasi dan manajemen aset terhadap kemampulabaan?

2. Bagaimana pengaruh arus kas operasi dan manajemen aset terhadap pertumbuhan perusahaan?

3. Bagaimana pengaruh arus kas operasi dan manajemen aset terhadap kemampulabaan dan pertumbuhan perusahaan?

\subsection{Maksud dan Tujuan Penelitian}

Maksud penulis dari penelitian ini yang berjudul "Pengaruh Arus Kas Operasi Dan Manajemen Aset Terhadap Kemampulabaan, Pertumbuhan Pertumbuhan", adalah untuk mengetahui seberapa besar pengaruh keterkaitan dari arus kas operasi dan manajemen aset terhadap kemampulabaan perusahaan, dan pertumbuhan perusahaan.

Tujuan dari penelitian ini adalah :

1. Untuk dapat mengetahui pengaruh arus kas operasi dan manajemen aset terhadap kemampulabaan. 
2. Untuk dapat mengetahui pengaruh arus kas operasi dan manajemen aset terhadap pertumbuhan perusahaan.

3. Untuk dapat mengetahui bagaimana pengaruh arus kas operasi dan manajemen aset terhadap kemampulabaan dan pertumbuhan perusahaan.

\section{$1.4 \quad$ Kegunaan Penelitian}

Kegunaan penelitian ini mencakup dua bagian, yaitu :

a. Kegunaan Teoritis

Untuk mengembangkan ilmu pengetahuan, yaitu agar dapat mengetahui dan memahami lebih mendalam mengenai arus kas operasi, manajemen aset, kemampulabaan dan pertumbuhan perusahaan.

b. Kegunaan Operasional

Untuk membantu memecahkan dan mengantisipasi masalah yang ada pada lokasi yang akan diteliti. Adapun pihak - pihak yang terkait dalam membantu untuk memecahkan masalah ini adalah sebagai berikut :

(1) Bagi Penulis

Bagi penulis dengan dilakukannya penelitian ini, maka dapat memberikan manfaat untuk menambah wawasan dan pengetahuan secara teori ketika di dalam perkuliahan maupun secara praktek tentang arus kas operasi (cash flow operational), manajemen aset (asset management), kemampulabaan (profitability) dan pertumbuhan perusahaan (sales growth ratio) dalam suatu perusahaan.

(2) Bagi Pembaca

Dari hasil penelitian ini diharapkan dapat memberikan pengetahuan tambahan bagi pembaca, menambah wawasan dan dapat memberikan informasi - informasi yang berguna bagi pembaca 
tentang arus kas operasi, manajemen aset, kemampulabaan dan pertumbuhan perusahaan, serta dapat juga sebagai bahan literatur untuk penelitian yang lebih lanjut.

(3) Bagi STIE Kesatuan

Bagi STIE Kesatuan diharapkan dengan dilakukanya penelitian ini dapat memberikan informasi mengenai arus kas operasi, manajemen aset, kemampulabaan dan pertumbuhan perusahaan untuk periode berikutnya yang akan melanjutkan penelitian yang berhubungan dengan penelitian ini.

(4) Bagi Perusahaan

Bagi pihak perusahaan dengan dilakukannya penelitian ini diharapkan untuk pihak perusahaan dapat mengelola laporan arus kas perusahaannya terutama pada laporan arus kas dari kegiatan operasinya dan dapat meningkatkan kemampulabaan perusahaan sehingga dengan bertambahnya kemampulabaan perusahaan, maka perusahaan dapat tumbuh dengan laba yang diperoleh semakin meningkat. Oleh karena itu dalam penelitian ini diharapkan dapat memberikan sumbangan pemikiran dan informasi dalam usaha untuk memecahkan masalah yang dihadapai oleh perusahaan 


\section{BAB II \\ TINJAUAN PUSTAKA}

\subsection{Kerangka Pemikiran Teoritis}

Dalam kerangka pemikiran teoritis akan diuraikan landasan - landasan teori yang memiliki keterkaitan dengan variabel skripsi, karena kerangka pemikiran teoritis merupakan modal konseptual yang menjelaskan hubungan antara teori dengan variabel - variabel yang akan diteliti, oleh karena itu dalam penyusunannya harus didukung oleh landasan teori yang kuat, ditunjang oleh informasi yang bersumber dari berbagai laporan, hasil penelitian - penelitian sebelumnya, konsultasi dan sebagainya.

\subsubsection{Manajemen Keuangan}

\subsubsection{Pengertian Manajemen Keuangan}

Menetapkan keputusan sementara menjadi keputusan terakhir dengan menyusun rencana manajemen keuangan bagi suatu perusahaan sangat penting dalam rangka menunjang pelaksanaan kegiatan operasional perusahaan tersebut. Keuangan perusahaan harus diatur sehemat mungkin agar tidak terjadi pemborosan keuangan, seperti dalam bentuk pengeluaran yang harus diatur sesuai dengan kebutuhan. Untuk itu penulis ingin mengemukakan beberapa pengertian tentang manajemen keuangan.

Sering terjadi salah penafsiran mengenai manajemen keuangan oleh banyak orang termasuk orang - orang yang terlibat dalam kegiatan keuangan perusahaan itu sendiri, berikut ini akan diperjelas mengenai pengertian manajemen keuangan yang dikemukakan oleh beberapa ahli.

Sedangkan pengertian manajemen keuangan menurut Abdul Halim $(2005,5)$ dalam bukunya Manajemen Keuangan (Dasar - Dasar Pembelanjaan 
Perusahaan) mengemukakan pengertian dari manajemen keuangan adalah "Manajemen keuangan merupakan suatu proses pengambilan keputusan dengan mengggunakan informasi akuntansi untuk membentuk organisasi di dalam mecapai tujuan".

Pengertian lainnya mengenai Manajemen Keuangan (Financial Management) dalam literatur lain disebut pembelanjaan dapat dijelaskan bahwa pengertian manajemen keuangan adalah segala aktivitas perusahaan yang berhubungan dengan bagaimana memperoleh dana, dan mengelola aset sesuai dengan tujuan perusahaan secara menyeluruh.

Maka dari beberapa pengertian manajemen keuangan diatas dapat diperoleh fungsi - fungsi dari manajemen keuangan adalah :

\section{Keputusan Investasi (Investment Decision)}

Keputusan investasi merupakan keputusan terhadap aktiva yang akan dikelola oleh perusahaan. Keputusan investasi ini merupakan keputusan yang paling penting diantara ke -3 keputusan manajemen keuangan. Hal ini karena keputusan investasi berpengaruh secara langsung terhadap besarnya rentabilitas investasi dan aliran perusahaan untuk waktu - waktu yang akan datang. Rentabilitas investasi (ROI) merupakan kemampuan perusahaan memperoleh laba yang dihasilkan dari investasi. Pengambilan keputusan yang keliru dalam investasi aktiva tersebut berakibat terganggunya pencapaian tujuan perusahaan.

\section{Keputusan Pendanaan (Financing Decision)}

Keputusan pendanaan akan mempelajari sumber - sumber dana yang di sisi kanan neraca. Keputusan pendanaan menyangkut mengenai sumber sumber dana yang diperlukan untuk membiaya investasi. Sumber dana yang akan digunakan untuk membiayai investasi tersebut dapat berupa hutang jangka 
panjang, hutang jangka pendek atau modal sendiri, oleh karena itu perlu ditetapkan apakah perusahaan menggunakan sumber modal eksternal yang berasal dari hutang dengan menerbitkan oblogasi atau menggunakan modal sendiri dengan menerbitkan saham baru. Kekeliruan dalam pengambilan keputusan pendanaan ini akan berakibat pada biaya yang akan ditanggung lebih besar. Biaya yang muncul berkaitan dengan keputusan pendanaan adalah biaya bunga untuk dana yang berasal dari hutang dan dividen yang berasal dari saham atau modal sendiri. Semakin besar laba yang ditahan berarti semakin kecil dana yang tersedia untuk pembayaran dividen. Sebaliknya semakin kecil laba yang ditahan maka semakin besar laba yang dibagi untuk pembayaran dividen.

\section{Keputusan Pengelolaan Aktiva (Assets Management Decision)}

Keputusan ke -3 dalam perusahaan adalah keputusan manajemen aktiva. Jika aktiva telah diperoleh dari pendanaan yang tepat telah tersedia, aktiva - aktiva yang ada tetap memerlukan pengelolaan yang efisien. Manager keuangan yang konervatif akan mengalokasikan dananya sesuai dengan jangka waktu aset yang didanai seperti aktiva lancar didanai oleh hutang lancar yang jangka waktunya lebih panjang dari usia aktiva lancar tersebut, akan tetapi yang tidak diusulkan pada pendanaan tanah yang dibiayai dengan modal sendiri.

\subsubsection{Tujuan Manajemen Keuangan}

Manajemen keuangan akan sangat berpengaruh terhadap semua keputusan perusahaan, untuk itu peran manajer keuangan dalam mencapai tujuan manajemen keuangan sangat vital terutama dalam proses pengambilan keputusan. Salah satu defenisi mengenai manajemen keuangan, yaitu :

Menurut Darmawan Sjahrial $(2006,4)$ :

Tujuan utama manajemen keuangan adalah memaksimalkan kemakmuran para pemilik perusahaan atau para pemegang saham. 
Tujuan ini dapat diwujudkan dengan cara memaksimumkan harga saham perusahaan.

Peran manajer keuangan dalam memaksimumkan harga saham adalah dengan mempengaruhi faktor - faktor sebagai berikut :

1. Laba per lembar saham (Earning Per Share / EPS) masa yang akan datang).

2. Ketepatan waktu (timing) dari arus penghasilan.

3. Risiko dari penghasilan yang diproyeksikan.

4. Cara memperoleh sumber dana untuk perusahaan.

5. Kebijakan dividen.

\subsubsection{Pengertian Kas}

Menurut Soemarso $(2004,296)$ "Kas adalah segala sesuatu baik yang berbentuk uang atau bukan yang dapat tersedia dengan segar dan diterima sebagai alat pelunasan kewajiban pada nilai nominalnya".

Menurut Zaki Baridwan $(2004,83)$ menyatakan “ Kas adalah aktiva yang tidak produktif oleh karena itu harus dijaga agar jumlah kas tidak terlalu besar".

Menurut Carl S Warren (2005, 284) didalam bukunya Accounting menyatakan bahwa :

"Cash include coins, currency (paper money), cheque, money orders and money deposit that is available for a unrecstricted withdrawal fromm banks and other financial institutions".

Sedangkan menurut Sofyan Syafri Harahap " Kas adalah uang dan surat berharga lainnya yang dapat diuangkan setiap saat serta surat berharga lainnya yang sangat lancar yang memenuhi syarat yaitu setiap saat dapat ditukar menjadi kas, tanggal jatuh temponya yang sangat dekat, kecil perubahan nilai yang disebabakan perubahan tingkat bunga".

Dari ke -4 pengertian tersebut, dapat disimpulkan bahwa kas adalah suatu pos yang sangat penting dalam sebuah perusahaan, dan yang paling likuid 
yang bisa digunakan kapan saja untuk kebutuhan kegiatan operasional perusahaan. Kas bisa termasuk kedalam bentuk uang kertas maupun uang logam baik yang berasal dari dalam negeri ataupun dari luar negeri, deposito, dan cek.

\subsubsection{Pengertian Arus Kas}

Setelah kita memahami pengertian kas, maka kita dapat mengidentifikasikan pengertian arus kas.

Arus kas seperti layaknya darah dalam tubuh manusia. Betapa pentingnya arus kas perusahaan agar upaya mencapai tujuan yang diharapkan tidak mengalami hambatan. Arus kas (cash flow) merupakan aliran kas yang ada diperusahaan dalam suatu periode tertentu. Cash flow menggambarkan beberapa uang masuk (cash in flow) ke perusahaan dan jenis - jenis pemasukan tersebut dan mengambarkan beberapa uang yang keluar (cash out flow) serta jenis - jenis biaya yang dikeluarkan.

Kelancaran kegiatan aktivitas perusahaan sangat tergantung pada arus kas tersebut. Sering dijumpai perusahaan yang berhenti beroperasi karena arus kasnya tidak mendukung untuk aktivitas rutinya setiap hari. Sebaliknya ada perusahaan yang merugi akan tetapi tetap terus beroperasi akibat dukungan arus kas yang berarti.

Arus kas atau disebut juga cash flow menurut Kasmir dan Jakfar (2003, 145) menyatakan bahwa :

Merupakan aliran kas yang ada di perusahaan dalam suatu periode tertentu. Arus kas menggambarkan berapa uang masuk ke perusahaan serta jenis - jenis pemasukan dan pengeluaran tersebut. Sehingga dapat dikatakan arus kas adalah jumlahuang yang masuk dan keluar perusahaan mulai dari investasi dilakukan sampai dengan berakhirnya investasi tersebut. 
Dalam laporan diatas kas dan surat berharga lainnya dapat diuangkan setiap saat serta surat berharga lain yang sangat lancar yang memenuhi syarat sebagai berikut :

a. Setiap saat dapat ditukar menjadi kas

b. Tanggal jatuh temponya dekat

c. Kecil resiko perubahan yang disebabkan perubahan tingkat bunga.

Pengertian arus kas menurut Higgins Robert C $(2000,19)$ menyatakan bahwa :

"Cash flow is very simple it is movement of money into of out a cash account over a period of time".

Dari kutipan tentang pengertian arus kas diatas, maka dapat disimpulkan bahwa arus kas ini banyak memberikan informasi tentang kemampuan perusahaan dalam mendapatkan laba dan kebutuhan modal kerja perusahaan di masa yang akan datang, karena melihat aliran kas yang terjadi pada perusahaan tersebut selama satu periode.

Pada umumnya arus kas selalu bernilai positif, meskipun demikian kadang - kadang kita menjumpai arus kas yang bernilai negatif. Arus kas yang bernilai negatif ini dapat disebabkan oleh penerimaan yang didapat oleh perusahaan lebih kecil dibandingkan dengan pengeluarannya.

Penerimaan dan pengeluaran kas yang diatur sedemikian rupa sehingga meninggalkan sisa kas minimum dinamakan sinkronisasi aliran kas, sinkronisasi aliran kas adalah salah satu usaha untuk mendapatkan kas yang ekonomis. Penerimaan dan pengeluaran kas akan lebih tepat bila sebelumnya telah dilakukan peramalan kas. Peramalan kas secara praktis dapat dilaksanakan dengan metode - metode sebagai berikut :

\section{Direct Estimated Cash}


Metode peramalan ini sangat mendetail dengan memasukkan segala unsur pengeluaran dan penerimaan kas. Bentuk - bentuk susunannya tidak lain merupakan proyeksi kas. Metode ini banyak dipakai oleh perusahaan perusahaan dan sangat berguna dalam memberi gambaran sirkulasi kas masuk dan kas keluar. Bagi perusahaan dengan aktivitas tinggi, metode ini sangat sesuai karena dapat melakukan pengawasan aliran kas melalui perbandingan pelaksanaan aktual dengan hasil peramalan sebelumnya.

\section{Adjusted Net Income Method}

Metode ini dimulai dengan penggunaan income and expanse statement (perincian penerimaan dan pengeluaran kas).

Taksiran net income yang terproyeksi ini mengalami adjustment terrhadap semua transaksi non kas hingga diperoleh laba atau rugi kas. Kemudian dilakukan lagi proses adjustment terhadap hasilnya dengan transaksi yang timbul dari operasi non operasi. Karena menggunakan net income, maka batas penerimaan dan pengeluaran kas kotor dapat diketahui.

Metode ini hanya cocok dipakai pada volume penjualan yang relatif stabil dan pengeluaran biaya - biaya yang tidak terduga yang cukup konstan bila dihubungkan dengan penjualan.

\section{Working Capital Differentials}

Dengan metode ini, dilakukan terhadap modal kerja netto pada tiap - tiap awal bulan dengan net income yang ditaksir berikut penerimaan dan pengeluaran lain - lain. Hasilnya adalah jumlah modal kerja yang ditaksir untuk setiap akhir bulan. Modal kerja tersebut dikurangi dengan modal kerja yang diperlukan (tidak termasuk kas dan saldo kas standar) untuk mendapatkan jumlah kas yang tersediaa sebagai deposito dan investasi.

Metode ini diterapkan jika standar penilaian piutang, persediaan, dan modal kerja lainnya yang dibutuhkan pada berbagai tingkat penjualan yang telah 
ditetapkan. Metode ini sesuai jika tujuan penggunaan kas sebagai investasi ulang dana yang tersisa.

Relevant cash flow adalah arus kas tertentu yang harus dipertimbangkan dalam mengambil keputusan dengan capital budgeting.

Penentuan aliran kas dalam capital budgeting merupakan aktivitas yang sangat penting, kesalahan dalam penentuan aliran kas dapat mengakibatkan kesalahan dalam penentuan pengambilan keputusan dalam capital budgeting. Aliran kas merupakan jumlah kas keluar dan kas masuk dari akibat melakukan investasi. Untuk menentukan aliran kas ini cukup sulit karena adanya pengaruh pajak, penyusutan, inflasi, nilai sisa, dan sebagainya.

Dalam penilaian usulan investasi, kebanyakan perusahaan memperhitungkan berdasarkan aliran kas bukan berdasarkan keuntungan menurut akuntansi. Hal ini sesuai dengan prinsip nilai waktu uang, dimana dari uang yang sama diterima atau dibayarkan pada waktu yang berbeda akan memiliki nilai yang berbeda. Sehingga dalam penilaian investasi didasarkan pada kapan uamg tersebut dikembalikan, dengan kata lain dalam penilaian investasi didasarkan aliran kas yang terjadi. Sebagai contoh penyusutan yang merupakan biaya pada periode yang bersangkutan, namun karena perusahaan tidak mengeluarkan kas secara nyata maka biaya penyusutan tersebut tidak diperhitungkan sebagai biaya.

Untuk menentukan arus kas relevan ada beberapa hal yang harus diperhatikan, yaitu :

1. Taksirlah arus kas atas dasar setelah pajak. Perhatikan bahwa yang dinikmati oleh pemilik perusahaan adalah arus kas masuk bersih setelah pajak.

2. Taksiral arus kas atas dasar incremental / selisih. Rencana peluncuran produk baru mungkin akan mengurangi penjualan produk lama (kanibalisme). Lebih lebih jika produk tersebut mempunyai pangsa pasar yang sama. Dengan 
demikian perlu diperhatikan kas masuk dari produk lama akibat peluncuran produk baru.

3. Taksirlah arus kas yang timbul karena keputusan investasi. Arus kas karena keputusan pendanaan, seperti membayar bunga pinjaman, megandung unsur pokok pinjaman, dan pembayaran dividen tidak perlu diperhatikan, perhatikan yang kita analisis adalah profitabilitas investasi sehingga unsur bunga tidak boleh dihitung.

4. Jangan memasukkan sunk cost (biaya yang telah terjadi sehingga tidak akan berubah karena keputusan yang kita ambil). Hanya biaya yang berubah karena keputusan kitalah yang relevan dalam analisis.

\subsubsection{Laporan Arus Kas}

\subsubsection{Pengertian Laporan Arus Kas}

Menurut Henry Simamora (2000, 487) mengemukakan bahwa “ Laporan arus kas adalah laporan keuangan yang memperlihatkan pengaruh dari aktivitas - aktivitas operasi, pendanaan, dan investasi perusahaan terhadap arus kas selama periode akuntansi tertentu dalam suatu cara yang merekonsiliasi saldo awal dan saldo akhir".

Menurut Sofyan Syafri Harahap $(2004,257)$ yang dimaksud dengan laporan arus kas adalah "laporan arus kas memberikan informasi yang relevan tentang penerimaan dan pengeluaran kas suatu perusahaan pada suatu periode tertentu dengan mengklasifikasikan transaksi pada kegiatan operasi, pembiayaan, dan investasi".

Menurut Drs. Harnanto. M. Soc. Sc,. Ak $(2002,129)$ “ Laporan arus kas adalah laporan keuangan yang menyajikan informasi tentang penerimaan dan pengeluaran kas perusahaan harus benar - benar memiliki kas dan bukannya laba bersih". 
Sedangkan menurut Shahrul dan M. Afdi Nazar (2000, 148) yang dimaksud dengan laporan aliran kas adalah suatu laporan keuangan yang menunjukkan sumber - sumber kas dan penggunaan kas yang masuk atau keluar dalam suatu bisnis".

Kas selalu membutuhkan perencanaan. Aspek utama perencanaan kas adalah penyusunan anggaran kas. Manajemen harus menyiapkan proyeksi yang berkaitan dengan arus kas masuk (cash inflow), arus kas keluar (cash outflow) dan saldo kas (balance). Perencanaan kas perlu disiapkan agar keseimbangan antara dana yang dibutuhkan untuk membiayai operasi perusahaan setiap hari dan dana yang dibutuhkan untuk investasi dapat terjaga.

Laporan arus kas menurut Carl S Warren dalam buku "Accounting" menyatakan bahwa :

"The statement cash flow reports a firm's major cash inflow and outflow for a period. It provides useful about a firm's ability to generate cash from operations, maintain and expand its operating capacity, meet its financial obligations, and pay dividens". (2005, 641)

Munawir (2002, 159) dalam bukunya Analisa Laporan Keuangan, menjabarkan sumber - sumber penerimaan kas dan sumber - sumber pengeluaran kas perusahaan, diantaranya adalah :

1. Sumber - Sumber Penerimaan Kas

a. Hasil penjualan investasi jangka panjang, aktiva tetap baik yang berwujud maupun tidak berwujud (Intangible assets), atau adanya penurunan aktiva tidak lancar yang diimbangi dengan penambahan kas.

b. Penjualan atau adanya emisi saham maupun penambahan modal oleh pemilik perusahaan dalam bentuk kas.

c. Pengeluaran surat tanda bukti hutang baik jangka pendek (wesel) maupun hutang jangka panjang ( hutang obligasi, hutang hipotik, atau hutang 
jangka panjang lainnya), serta bertambahnya hutang yang diimbangi dengan penerimaan kas.

d. Adanya penurunan atau berkurangnya aktiva lancar selain kas yang diimbangi dengan adanya penerimaan kas, misalnya adanyan penurunan piutang karena diterimanya pembayaran piutang, berkurangnya persediaan barang dagangan karena adanya penjualan secara tunai. Dan adanya penurunan surat berharga (efek) karena adanya penjualan dan sebagainya.

e. Adanya penerimaan kas karena sewa, bunga, atau dividen dari investasi investasinya, sumbangan atau hadiah maupun adanya pengembalian kelebihan pembayaran pajak pada peroide sebelumnya.

2. Sumber - Sumber Pengeluaran Kas Perusahaan

a. Pembelian saham atau obligasi sebagai investasi jangka pendk maupun jangka panjang serta adanya pembelian aktiva tetap lainnya.

b. Penarikan kembali saham yang beredar maupun adanya pengembalian kas perusahaan oleh pemilik perusahaan.

c. Pelunasan atau pembayaran angsuran hutang jangka pendek maupun jangka panjang.

d. Pembelian barang dagangan secara tunai, adanya pembayarn biaya operasi yang meliputi upah dan gaji, pembayaran sewa, bunga, premi asuransi, dan adanya persekot - persekot biaya maupubn persekot pembelian.

e. Pengeluaran kas untuk pembayaran dividen (bentuk pembagian laba lainnya secara tunai), pembayaran pajak, denda - denda, dan lain sebagainya.

Aliran kas masuk dan aliran kas keluar akan terus terjadi didalam perusahaan secara terus - menerus selama perusahaan masih beroperasi. 
Untuk itu kedua macam aliran kas tersebut harus diatur dengan baik agar efektif, sehingga perlu dibuat rencana atau anggaran untuk setiap periodenya, dari mana saja sumber pemasukkan kas didapat dan untuk apa saja kas tersebut digunakan. Tujuannya adalah untuk mengantisipasi jika terjadi kekurangan kas dapat dicari sumber atau solusinya, dan jika terjadi kelebihan kas yang terlalu besar maka harus dipikirkan atau diputuskan akan diinvestasikan karena kelebihan kas tersebut. Penerimaan dan pengeluaran aliran kas juga mempunyai faktor - faktor yang mempengaruhinya, antara lain :

\section{Tabel 2.1}

Faktor - Faktor Yang Mempengaruhi Penerimaan Dan Pengeluaran Kas

\begin{tabular}{|c|c|}
\hline $\begin{array}{c}\text { Faktor - faktor yang } \\
\text { mempengaruhi penerimaan kas : }\end{array}$ & $\begin{array}{c}\text { Faktor - faktor yang } \\
\text { mempengaruhi pengeluaran } \\
\text { kas : }\end{array}$ \\
\hline 1. Budget penjualan & $\begin{array}{l}\text { 1.Budget biaya tenaga kerja } \\
\text { langsung }\end{array}$ \\
\hline 2. Keadaan dari posisi pesaing & $\begin{array}{l}\text { 2.Budget biaya pabrik lain - lain } \\
\text { (FOH) }\end{array}$ \\
\hline 3. Syarat pembayaran & $\begin{array}{l}\text { 3. Budget biaya administarsi } \\
\text { umum }\end{array}$ \\
\hline 4. Kebijaksanaan dalam penagihan piutang & $\begin{array}{l}\text { 4.Budget penambahan aktiva } \\
\text { tetap }\end{array}$ \\
\hline 5. Budget perubahan aktiva tetap & $\begin{array}{l}\text { 5.Budget pengeluaran non } \\
\text { operating }\end{array}$ \\
\hline \multicolumn{2}{|l|}{ 6. Rencana penerimaan non operating } \\
\hline $\begin{array}{l}\text { 7.Kebijaksanaan penelitian surat - surat } \\
\text { berharga }\end{array}$ & \\
\hline
\end{tabular}

Selain transaksi - transaksi diatas ada juga transaksi - transaksi yang tidak mempengaruhi arus kas antara lain :

1. Adanya pengakuan atau pembebanan depresiasi, amortisasi terhadap aktiva tetap.

2. Adanya pengakuan kerugian piutang baik dengan membentuk cadangan piutang maupun tidak dan adanya piutang tak tertagih. 
3. Adanya penghapusan atau pengurangan nilai buku dari aktiva yang dimiliki serta penghentian penggunaan aktiva tetap karena telah habis disusutkan atau tidak dapat digunakan lagi.

4. Adanya pembayaran dividen dalam bentuk saham ( stock dividen), adanya pembatasan penggunaan laba serta adanya kembali aktiva tetap yang ada.

Aliran kas suatu perusahaan harus dikelola dengan baik, sebab ia merupakan jantung yang menggerakan kegiatan operasi. Sehingga dapat dikatakan sehat atau tidaknya suatu perusahaan dapat dilihat dari perputaran cash flow perusahaan yang bersangkutan, karena didalam arus kas kita dapat melihat jumlah kas yang sesungguhnya.

Di dalam Standar Akuntansi Keuangan (SAK) No.2 (2002, 221) yang dimaksud dengan arus kas adalah arus kas masuk dan arus kas keluar atau setara kas. Sedangkan yang dimaksud dengan setara kas yaitu investasi yang sifatnya likuid, berjangka pendek dan yang paling penting cepat dijadikan kas dalam jumlah tertentu tanpa menghadapi resiko nilai yang signifikant.

\subsubsection{Tujuan Laporan Arus Kas}

Menurut Drs. Mahmud M. Hanafi, MBA dan Drs. Abdul Haim, MBA. Akt $(2000,63)$ “ Laporan arus kas dipakai untuk menganalisis arus kas masuk dan keluar kas perusahaan. Laporan arus kas bertujuan untuk melihat efek kas dari kegiatan operasional, investasi dan pendanaan suatu perusahaan selama periode tertentu. Selain itu laporan arus kas dapat memasok informasi yang memungkinkan para pemakai untuk mengevaluasi perubahan dalam aktiva bersih perusahaan, struktur keuangan (termasuk likuiditas, solvabilitas) dan kemampuan untuk mempengaruhi jumlah serta waktu arus kas dalam rangka adaptasi dengan perubahan keadaan dan peluang bisnis". 
Menurut Henry Simamora $(2000,488)$ dalam bukunya yang berjudul Akuntansi Bisnis Pengambilan Keputusan Bisnis jilid 2, memamparkan tujuan dan manfaat laporan arus kas sebagai berikut :

1. Untuk memperkirakan arus kas dimasa mendatang. Biasanya sumber dan penggunaan kas pada perusahaan tidaklah berubah secara dramatis dari tahun ke tahun. Oleh karena itu laporan arus kas dapat diterima sebagai alat yang baik untuk memperkirakan penerimaan dan pengeluaran kas di masa mendatang.

2. Untuk mengevaluasi pengambilan keputusan manajemen. Laporan arus kas akan melaporkan kegiatan investasi perusahaan sehingga memberikan informasi arus kas kepada investor dan kreditor untuk mengevaluasi keputusan manajemen.

3. Untuk menentukan kemampuan perusahaan membayar dividen kepada pemegang saham, pembayaran bunga dan pokok pinjaman kepada kreditor. Laporan arus kas mebantu investor untuk mengetahui apakah perusahaan bisa melakukan pembayaran ini.

4. Untuk menunjukkan hubungan laba bersih terhadap perubahan kas perusahaan. Biasanya kas dan laba bersih bergerak bersamaan. Tingginya tingkat laba cenderung menyebabkan peningkatan kas dan sebaliknya, akan tetapi nilai sisa kas bisa meningkat ketika alaba rendah. Adanya kemungkinan bangkrut suatu perusahaan yang mempunyai laba bersih yang cukup tetapi kas yang rendah, menyebabkan diperlukannya informasi arus kas. 


\subsubsection{Manfaat Arus Kas}

Arus kas sangat bermanfaat baik secara internal maupun eksternal. Dengan melakukan analisis arus kas kita dapat mengetahui :

a. Kemampuan perusahaan menghasilkan kas, merencanakan, mengontrol arus kas masuk dan arus kas keluar perusahaan pada masa lalu. Sehingga pada masa yang akan datang perusahaan dapat lebih menggunakan kas secara efektif dan efisisen.

b. Kemungkinan keadaan arus kas masuk dan arus kas keluar, arus kas bersih perusahaan, termasuk kemampuan membayar dividen dimasa yang akan datang.

c. Informasi bagi investor dan kreditor, memproyeksikan return dari sumber kekayaan perusahaan. Sebagai pihak yang menanamkan dana pada perusahaan, kreditor dan investor berkepentingan terhadap kemampuan perusahaan dalam membayar kewajiban dan pengembalian modalnya.

d. Kemampuan perusahaan untuk menghasilkan kas ke perusahaan di masa yang akan datang. Sebagai dasar perencanaan kegiatan operasional perusahaan.

e. Alasan perbedaan antara laba bersih dibandingkan dengan penerimaan dan pengeluaran kas.

f. Pengaruh investasi baik kas maupun bukan kas dan transaksi lainnya terrhadap posisi keuangan perusahaan selama satu periode tertentu. 


\subsubsection{Macam - Macam Arus Kas}

\section{A. Aktivitas Operasi}

Aktivitas operasi adalah aktivitas penerimaan dan pengeluaran kas yang ditunjukan untuk kegiatan operasional perusahaan dalam suatu periode. Semua transaksi yang berkaitan dengan laba yang dilaporkan dalam laporan laba/rugi dikelompokkan dalam golongan ini. Demikian juga arus kas masuk lainnya yang berasal dari kegiatan operasional.

B. Aktivitas Investasi

Aktivitas investasi adalah aktivitas perolehan dan pelepasan aktiva jangka panjang serta investasi lainnya yang tidak termasuk kas dan setara kas. Setara kas ini dibutuhkan unutk memenuhi kebutuhan kas jangka pendek, bukanb untuk tujuan investasi ataupun tujuan yang lainnya. Pengungkapan terpisah dari aktivitas operasi dan aktivitas pendanaan, karena arus kas tersebut mencerminkan penerimaan dan pengeluaran kas sehubungan dengan sumber daya yang bertujuan untuk menghasilkan pendapatan dan arus kas dimasa yang akan datang.

Para pembuat keputusan berkepentingan dengan bagian dari laporan arus kas karena menggambarkan bagaimana perusahaan mempersiapkan diri untuk masa mendatang. Apabila perusahaan mengeluarkan banyak dana untuk aset produktif, maka perusahaan itu akan mampu berkembang. Informasi dalam bagian aktivitas - aktivitas ini membantu para pengambil keputusan untuk memahami apa yang sudah dilakukan oleh perusahaan.

\section{Aktivitas Pendanaan}

Aktivitas pendanaan adalah aktivitas penerimaan dan pengeluaran kas yang mengakibatkan perubahan jumlah serta komposisi modal dan pinjaman perusahaan. Pengungkapan arus kas yang timbul dari aktivitas pendanaan 
perlu dilakukan karena bermanfaat untuk memprediksi klaim terhadap arus kas masa depan oleh para pemasok modal perusahaan.

\subsubsection{Klasifikasi Arus Kas}

Menurut Henry Simamora $(2000,491)$ : klasifikasi arus kas dapat dikemukakan sebagai berikut :

a. Jenis - jenis arus kas masuk dan arus kas keluar dari aktivitas operasi :

Arus kas masuk :

1. Penerimaan kas dari penjualan barang dan jasa

2. Penerimaan kas dari hasil pemberian pinjaman (bunga yang diterima) dan dari ekuitas surat berharga (dividen yang diterima).

Arus kas keluar :

1. Pembayaran kas kepada pemasok persediaan

2. Pembayaran kas kepada para karyawan atas jasanya

3. Pembayaran kas kepada pemerintah dalam bentuk pajak

4. Pembayaran kas kepada pemberi pinjaman dalam bentuk bunga

5. Pembayaran kas kepada pihak - pihak lainnya atas pengeluaran

b. Jenis - jenis arus kas masuk dan arus kas keluar dari aktivitas investasi :

Arus kas masuk:

1. Penerimaan kas dari penjualan properti, aktiva tetap dan perlengkapan.

2. Penerimaan kas dari penjualan surat utang atau ekuitas, surat berharga dari entitas lainnya.

Arus kas keluar :

1. Pembayaran kas untuk pembelian aktiva tetap.

2. Pembayaran kas untuk surat berharga atau utang dari entitas lainnya. 
3. Pembayaran kas untuk pemberian pinjaman kepada entitas lainnya.

c. Jenis - jenis arus kas masuk dan arus kas keluar dari aktivitas pendanaan :

Arus kas masuk:

1. Penerimaan kas dari surat berharga ekuitas (saham perusahaan sendiri)

2. Penerimaan kas dari penerbitan kewajiban (obligasi)

Arus kas keluar

1. Pembayaran kas kepada pemegang saham dalam bentuk dividen

2. Pembayaran kas untuk pelunasan utang jangka panjang.

\subsubsection{Arus Kas Operasi}

Arus kas dari kegiatan operasi merupakan aktivitas penghasil utama pendapatan perusahaan, dimana aktivitas tersebut pada umumnya berasal dari transaksi dan peristiwa lain yang mempengaruhi pendapatan laba atau rugi bersih. Arus kas dari kegiatan operasi merupakan transaksi - transaksi pembelian atau produksi barang - barang dan jasa serta penjualan dan distribusi barang dan jasa tersebut kepada pelanggan. Jumlah arus kas yang berasal dari kegiatan operasi merupakan indikator yang menentukan apakah dari kegiatan kegiatan yang cukup untuk meluansi pinjaman, memelihara kemampuan operasi perusahaan, membayar dividen, dan melakukan investasi baru.

Arus kas operasi (operational cash flow) menurut Sutrisno $(2001,133)$ menyatakan bahwa :

"Aliran kas yang akan dipergunakan untuk menutup investasi, biasanya diterima setiap tahun selama usia investasi dan beberapa aliran kas bersih".

Arus kas operasi menurut situs internet www.saham-bei.com menyatakan bahwa :

Arus kas operasi adalah arus kas yang terutama diperoleh dari aktivitas penghasil utama pendapatan perusahaan, oleh karena itu 
arus kas ini pada umumnya berasal dari transaksi dan peristiwa lain yang mempengaruhi laba atau rugi bersih.

Arus kas operasi menurut John J Wild, dkk $(2005,16)$ menyatakan bahwa :

Arus kas dari operasi berfokus pada aspek likuiditas perusahaan. Arus kas dari operasi bukan merupakan pengukuran profitabilitas, karena tidak mencakup biaya - biaya penting seperti penggunaan aktiva tetap dalam aktivitas operasi maupun pendapatan seperti ekuitas non kas dalam bentuk laba anak perusahaan atau perusahaan afililasi yang tidak terkonsolidasi.

Dari ketiga kutipan tentang pengertian arus kas operasi diatas, maka dapat disimpulkan bahwa arus kas operasi adalah sumber dan penggunaan kas yang dikeluarkan pada saat operasi usaha, seperti penjualan dan pembelian atau produksi barang dan jasa serta arus kas masuk dan keluar dari kegiatan operasi. Adapun rumus dari arus kas operasi adalah :

Arus kas operasi $(\mathrm{CFO})=$ Laba bersih + Penyusutan + Biaya non kas lainnya .

\subsubsection{Peranan Arus Kas Operasi}

Peranan arus kas operasi menurut E. Kieso Donald dkk (2002, 373) memiliki tujuan untuk membuat prediksi yang lebih baik atas jumlah waktu dan ketidak pastian arus kas dimasa depan dimana hal tersebut dapat dilakukan dengan memeriksa hubungan antara pos -pos seperti penjualan dan arus kas bersih dari kegiatan operasi serta kenaikan atau penurunan kas.

Hasil analisis dari arus kas operasi berguna bagi pihak manajemen untuk mengetahui perubahan apakah yang terjadi kenaikan atau penurunan serta penggunaannya apakah terdapat pos - pos yang membutuhkan atau kekurangan dana, sehingga diperlukan tambahan dana bagi proses kegiatan operasional tersebut. 


\subsubsection{Metode Laporan Arus Kas}

Laporan arus kas dapat dibuat dengan menggunakan 2 metode, yaitu metode langsung dan metode tidak langsung. Metode ini jika diterapkan akan memberikan hasil yang sama.

\section{A. Metode Langsung}

Dalam metode langsung memperlihatkan penerimaan kas dari pendapatan yang dibandingkan dengan pembayaran kas untuk pengeluaran. Pada metode ini pendapatan akrual diubah menjadi dasar kas. Metode langsung dianggap dapat memberikan laporan yang lebih terinci dan memfokuskan pada arus kas daripada laba perusahaan akrual, karena itu dianggap lebih informatif. Namun penyusunan arus kas dengan metode langsung ini lebih sulit dan memerlukan waktu yang lebih lama sehingga jarang digunakan oleh perusahaan.

B. Metode Tidak Langsung

Metode ini memfokuskan pada perbedaan antara laba/rugi bersih dengan arus kas yang terjadi dari aktivitas - aktivitas pengoperasian dan mudah untuk mengumpulkan dana yang diperlukan. Jadi pada dasarnya metode ini merupakan rekonsiliasi laba bersih yang diperoleh perusahaan dan biasanya sering digunakan oleh perusahaan, karena dalam penyusunannya lebih mudah dan sederhana dibandingkan dengan metode langsung.

Metode ini penyajiannya dimulai dari laba/rugi bersih dan selanjutnya disesuaikan dengan menambah atau mengurangi perubahan dalam pos pos yang mempengaruhi kegiatan operasional perusahaan seperti penyusutan, naik turunnya pos aktiva lancar dan hutang lancar. Dalam metode ini, menghitung arus kas dengan melakukan penyesuian terrhadap laba bersih akrual. 
Contoh : Format Laporan Arus Kas Metode Langsung ( Direct Method)

$$
\text { Laporan Arus Kas - Metode Langsung }
$$

Untuk Tahun Yang Berakhir 31 Desember 200A

a. Aliran kas dari kegiatan operasional

Kas masuk dari penjualan tunai $\quad x x x$

Kas keluar

Pembayaran tenaga kerja

Pembayaran kepada supplier

Pembayaran biaya operasi

$\underline{(x x x)}$

Aliran kas masuk(keluar) bersih dari kegiatan operasi

$x x x$

b. Aliran kas dari kegiatan investasi

Aliran kas masuk

Diterima dari penjualan aktiva

$x x x$

Aliran kas keluar

Dibayar untuk pembelian aktiva

$\underline{(x x x)}$

Aliran kas masuk(keluar) bersih dari kegiatan investasi

c. Aliran kas dari aktivitas pembiayaan

Aliran kas masuk

Diterima dari penjualan saham

$x x x$

Diterima dari obligasi jangka pendek

$x x x$

Aliran kas keluar

Dibayar pokok hutang jangka panjang

Dibayar saham treasury

Dibayar deviden

$\underline{(x x x)}$

Aliran kas masuk(keluar)bersih dari kegiatan pendanaan

d. Saldo kas awal dan akhir

Kenaikan penurunan kas periode ini

Saldo kas awal periode 
Contoh : Format Laporan Arus Kas Metode Tidak Langsung

\section{Laporan Arus Kas - Metode Tidak Langsung \\ Untuk Tahun Yang Berakhir 31 Desember 200A}

a. Aliran kas dari kegiatan operasional

Laba (rugi) bersih dari laporan $\quad$ xxx

Ditambah (dikurangi) penyesuaian laba terhadap arus kas

Kenaikan piutang dagang

Kenaikan persediaan

Biaya penyusutan

$\mathrm{XXX}$

Kenaikan hutang gaji

$\underline{\mathrm{XXX}}$

Aliran kas masuk (keluar) bersih dari kegiatan operasi

$\mathrm{XXX}$

b. Aliran kas dari kegiatan investasi

Aliran kas masuk

Diterima dari penjualan aktiva

$\mathrm{XXX}$

Aliran kas keluar

Dibayar untuk pembelian aktiva

$\underline{(x x x)}$

Aliran kas masuk (keluar) bersih dari kegiatan investasi

$\mathrm{XXX}$

c. Aliran kas dari kegiatan pembiayaan

Aliran kas masuk

Diterima dari penjualan saham

$\mathrm{XXX}$

Diterima dana obligasi jangka panjang

$\mathrm{XXX}$

Aliran kas keluar

Dibayar pokok hutang jangka panjang

Dibayar saham treasury

Dibayar deviden

Aliran kas masuk (keluar) bersih dari kegiatan pendanaan

d. Saldo kas awal dan akhir

Kenaikan penurunan kas periode ini

$\mathrm{XXX}$

Saldo kas awal periode ini

$\underline{X X X}$

Saldo kas akhir periode ini

$\mathrm{XXX}$

\subsubsection{Analisis Laporan Arus Kas}

Analisis arus kas sebenarnya sejalan dengan penyusunan laporan arus kas atau disebut juga cash flow statement. 
Menurut Drs. Munawir, Akt $(2004,37)$ : " Analisis arus kas adalah suatu analisa untuk mengetahui sebab - sebab perubahan jumlah kas atau unutk mengetahui sumber - sumber serta penggunaan kas selama periode tertentu".

Dan menurut Sofyan Syafri Harahap $(2001,201)$ : “Analisa arus kas dapat menunjukkan pergerakan arus kas darimana sumber kas diperoleh dan kemana dialirkan.

Analisis arus kas menurut situs internet oleh Susan Ward, About .com (2000) menyatakan bahwa :

"Cash flow analysis is the study of the cycle of your business cash inflows and outflows, with the purpose of maintaning an adequate cash flow for your business, and to provide the basis for cash flow management".

Oleh karena itu perkembangan laporan arus kas dari suatu periode ke perode tertentu perlu dianalisis karena sangat bermanfaat dalam perumusan dan pengendalian kegiatan opersional perusahaan untuk masa yang akan datang.

Arus kas yang terus meningkat secara maksimal adalah essensial bagi tujuan kunci manajemen. Apabila arus kas melebihi kebutuhan operasi dan ekspansi usaha, maka perusahaan tentunya tidak perlu meminjam tambahan dana. Arus kas yang berlebihan ini akan tersedia untuk mengurangi hutang perusahaan dan meningkatkan posisi keuangannya dengan menurunkan rasio hutang terhadap modalnya.

Dengan melakukan analisis arus kas ini, kita dapat mengetahui :

1. Kemampuan perusahaan mengelola kas, merencanakan, mengontrol arus kas masuk dan arus kas keluar pada masa lalu.

2. Kemungkinan keadaan arus kas masuk dan arus kas keluar, arus kas bersih perusahaan, termasuk kemampuan perusahaan membayar dividen di masa yang akan datang. 
3. Informasi bagi investor dan kreditor untuk memproyeksikan return dari sumber kekayaan perusahaan.

4. Kemampuan perusahaan untuk memasukkan kas ke perusahaan di masa yang akan datang.

5. Alasan perbedaan antara laba bersih dibandingkan dengan penerimaan dan pengeluaran kas.

6. Pengaruh investasi baik kas maupun bukan kas dan transaksi lainnta terhadap posisi keuangan perusahaan selama satu periode tertentu.

Pada saat kita menganalisis perkiraan arus kas dimasa yang akan datang, kita berhadapan dengan ketidakpastian, akibatnya hasil perhitungan diatas kertas itu dapat menyimpang jauh dari kenyataanya. Ketidak pastian itu dapat menyebabkan berkurangnya kemampuan untuk development proyek tersebut dalam beroperasi untuk menghasilkan laba bagi perusahaan. Apabila dijumpai beberapa proyek yang layak untuk dilaksanakan, padahal hanya akan melaksanakan satu atau sebagian saja dari usulan - usulan tersebut karena keterbatasan sumber daya manusia dan dana,maka dapat dilalukan pengurutan prioritas (rangking) usulan proyek yang paling layak. Dari hasil analisis terhadap elemen - elemen aspek keuangan nanti akan berupa suatu pernyataan apakah rencana bisnis dianggap layak atau tidak layak.

Untuk menganalisis laporan arus kas dapat dilihat dari dua keadaan. Adalah sebagai berikut :

1. Menganalisis laporan arus kas yang sudah dibuat oleh perusahaan.

2. Melakukan analisis berdasarkan informasi hanya dari laporan neraca dan laba/rugi. Dengan kata lain laporan arus kasnya belum ada.

Oleh karena itu perkembangan laporan arus kas dari satu periode ke periode tertentu perlu dianalisis karena sangat bermanfaat dalam perumusan dan pengendalian kegiatan operasional perusahaan untuk masa yang akan datang. 


\subsubsection{Manajemen Aset}

\subsubsection{Pengertian Manajemen Aset}

Setiap perusahaan umumnya menerapkan sistem manajemen aset, karena segala sesuatu yang terjadi di dalam perusahaan membutuhkan pengelolaan untuk mencegah penyimpangan-penyimpangan yang akan terjadi dan mengatasi penyimpangan yang sudah terjadi baik dalam kegiatan operasionalnya maupun non operasionalnya dengan melakukan feedback. Berikut ini akan diuraikan teori mengenai definisi manajemen aset.

Menurut market valas.blogspot.com/2008/08/_manajemen aset. html mendefinisikan "Manajemen aset adalah suatu potensi yang dimiliki oleh organisasi atau perseorangan untuk mencapai visi, misi dan tujuan khususnya".

Menurut www.daton.com/id/article mendefinisikan Manajemen Aset sebagai berikut, "Manajemen Aset menyediakan bagi perusahaan untuk perjalanan aset secara keseluruhan, tidak hanya untuk melihat aset mana saja yang dibeli dan berapa biayanya, aset mana yang digunakan dan bagaimana mereka dimanfaatkan, dimana lokasi mereka, termasuk dalam biaya apa, tetapi juga membantu mencegah hilangnya atau pencurian dari aset”.

Sedangkan menurut www.wordpress.com manajemen aset dapat didefenisikan sebagai "Suatu manajemen proses secara global untuk membuat dan mengeksekusi nilai keputusan tertinggi tentang penggunaan dan perawatan aset secar konsisten". Konsep dasar manajemen aset berbasisi pada tiga hal, yaitu sebagai berikut :

1. Tujuan perusahaan yang merupakan arah keputusan, berdasarkan pada kegunaan dan kepedulian terhadap aset peralatan.

2. Startegi aset yang ditentukan berdasarkan pada pertimbangan operasional. 
3. Perawatan dan reabilitas berdasarkan pada tujuan yang telah ditetapkan.

\subsubsection{Macam-macam Aktiva}

Menurut Basu Swastha, dkk (2000, 321-322) menyatakan bahwa :

Aktiva merupakan kekayaan fisik yang dimiliki oleh perusahaan, dibagi kedalam : (a) aktiva lancar, (b) aktiva tetap, dan (c) aktiva tidak kentara.

a. Aktiva lancar

Aktiva lancar adalah kekayaan perusahaan yang berupa uang tunai (kas) dan kekyaan lain yang mudah diuangkan (atau dalam jangka waktu pendek dapat ditukarkan menjadi uang tunai), seperti piutang, surat-surat berharga, persekot, persediaan barang.

b. Aktiva tetap

Aktiva tetap adalah kekayaan yang dimiliki oleh perusahaan dalam jangka waktu lama, seperti : gedung, tanah, mesin-mesin, dan sebagainya.

c. Aktiva yang tidak kentara

Aktiva yang tidak kentara adalah aktiva yang secara fisik tidak dapat dilihat atau diraba tetapi secara riil mempunyai nilai, seperti : hak patent, hak cipta, goodwiil.

Bagian dari pasiva pada sebuah neraca perusahaan berisi sekelompok pos, yaitu (a) utang lancar, (b) utang jangka panjang, dan (c) modal sendiri.

a. Utang lancar

Utang lancar adalah kewajiban finansial perusahaan yang harus dilunasi dalam jangka waktu yang relatif pendek. Pelunasan tersebut biasanya dilakukan dengan mengambil aktiva lancarnya. Pos-pos yang termasuk dalam aktiva lancar antara lain : utang dagang, kredit rekening koran, kredit wesel, kredit pembelian, utang deviden, dan sebagainya. 
b. Utang jangka panjang

Utang jangka panjang adalah kewajiban finansial perusahaan yang harus dilunasi dalam jangka waktu (lebih dari 1 tahun), seperti : utang obligasi, dan utang hipotik.

C. Modal sendiri

Modal sendiri adalah sejumlah uang yang ditanamkan dalam sebuah perusahaan untuk menjalankan kegiatannya. Dalam perseroan terbatas peranan modal ini disebut pemegang saham sebab modalnya diwujudkan dalam bentuk saham. Sering pula terdapat bahwa laba yang diperoleh perusahaan tidak dibagikan kepada pemilk tetapi ditanami kembali dalam perusahaan, dikenal sebagai laba yang ditahan.

\subsubsection{Manajemen Kas}

Salah satu perhatian utama dari manajer keuangan adalah bagaimana memperkirakan, merencanakan, serta mengontrol besarnya kas yang optimal demi kelancaran usahanya. Walaupun selama ini manejemen kas kurang mendapat perhatian dari para manajer keuangan, namun seiring dengan meningkatnya tingkat suku bunga yang tersedia untuk investasi maka manajemen kas merupakan salah satu pendekatan dalam mengelola kas secara efisien.

Menurut C Van Horne $(2001,394)$ dalam bukunya Financial Management And Policy "Cash management involves managing the monies of the firm in order to maximize cash availability and interest income on any idle funds".

Menurut Stanley B. Block and Geoffrey A. Hirt $(2005,174)$ dalam bukunya Foundations of Financial Management menyatakan bahwa "Cash management 
involves control over the receipt and payment of cash as to minimize nonearing cash balance".

Adapun tujuan dari manajemen kas menurut Eugene F. Brigham (2000, 689) dalam bukunya Fundamentals of Financial Management yaitu :

Goal of cash managemenet is to minimize the amount of cash the firm must hold use in conducting it's normal business activities, yet at the same time to have sufficient cash (1) to take trade discount, (2) maintant it's credit rating and, (3) to meet unexpected cash needs.

Menurut Ridwan S. Sundjaja, dkk $(2003,237)$ dalam buku Manajemen Keuangan menyatakan bahwa "Tujuan dari manajemen kas adalah mempertahankan tingkat saldo kas transaksi dan investasi surat berharga yang dikontribusikan untuk meningkatkan nilai perusahaaan”.

Manajemen kas telah mengalami perubaahan penting selama 20 tahun terakhir sebagai akibat dari dua faktor. Pertama, dari awal tahun 1970-an sampai pertengahan tahun 1980-an, suku bunga cenderung naik, yang meningkatkan biaya kesempatan untuk menahan kas. Hal ini mendorong para manajer keuangan untuk mencari cara yang lebih efisien untuk mengelola kas perusahaan. Kedua perkembangan teknologi, terutama mekanisme transfer dana elektronik terkomputerisasi, telah mengubah cara pengelolaan uang kas. Kebanyakan aktivitas manajemen kas dilaksanakan secara bersama oleh perusahaan dan banknya.

Menurut Ridwan S. Sundjaja, dkk $(2003,241)$ manajemen kas yang efektif menekankan pada pengelolaan yang tepat atau arus kas masuk dan arus kas keluar, yang berarti dalam pelaksanaanya memilki teknik-teknik sebagai berikut : 


\section{Sikronisasi Arus Kas}

yang dimaksud dengan hal tersebut adalah suatu situasi dimana arus kas masuk diselaraskan dengan arus kas keluar, sehingga memungkinkan suatu perusahaan mempertahankan saldo kas untuk keperluan transaksi yang rendah.

\section{Mempercepat Proses Kliring Cek}

yaitu suatu proses pengkonversian sejumlah kas dalam bentuk cek yang telah ditulis dan dikirimkan menjadi uang kas dalam rekening yang dibayar

\section{Memanfaatkan Masa Mengambang}

Masa mengambang (float) didefinisikan sebagai perbedaan antara saldo yang diperlihatkan dalam buku cek sebuah perusahaan (atau perorangan) dan saldo pada catatan bank. Pada teknik ini terdapat beberapa faktor yang ditimbulkan dalam penentuan nilai cek yang diterima antara lain :

a. Pengeluaran Mengambang (disbursement float)

nilai dari cek-cek yang telah kita tulis tetapi yang masih diproses sehingga belum dikurangkan dari saldo rekening kita oleh bank.

b. Penagihan Mengambang (collecting float) jumlah cek-cek yang telah kita terima tetapi yang belum dikredit ke rekening kita.

c. Nilai mengambang bersih (net float)

Selisih diantara saldo rekening bank menurut pembukuan pemegang rekening dengan saldo rekening menurut pembukuan bank.

\section{Mempercepat Penerimaan}

Dalam proses melakukan percepatan penerimaan kas terdapat banyak hal yang dapat dilakukan antara lain membuka cek mundur, pemberian 
cash discount sehingga pelanggan tertarik untuk membayar tunai, dan lain sebagainya.

5. Memperlambat Pembayaran

Beberapa cara yang lazim dilakukan misalnya membuka bilyet giro dengan tanggal mundur untuk tagihan jatuh tempo. Penggabungan beberapa tagihan sekaligus dan pengeluaran kas sesuai tanggal piutang terbaru yang jangka waktu pelunasan paling lama.

\subsubsection{Kemampulabaan}

\subsubsection{Pengertian Kemampulabaan}

Perusahaan pada umumnya mempunyai tujuan diantaranya laba, karena dengan laba dapat dilihat kondisi kesehatan perusahaan tersebut. Perusahaan yang memiliki laba yang maksimal berarti perusahaan tersebut mempunyai kemampuan untuk memenuhi kewajiban - kewajiban serta mampu mengelola asset yang dimilikinya seoptimal mungkin.

Kemampulabaan merupakan masalah sentral daru sustu perusahaan, karena penciptaan nilai dilakukan melalui penciptaan laba. Begitu pula kemakmuran pemilki perusahaan. Kemampulabaan juga merupakan refleksi dari kualitas manajemen dalam mengelola sumber daya perusahaan.

Dalam istilahnya kemampulabaan dapatdiartikan sebagai profitabilitas atau rentabilitas, karena istilah - istilah tersebut mempunyai arti yang sama yaitu suatu kemampuan perusahaan untuk menghasilkan keuntungan dari penjualan barang dan jasa yang diproduksinya. Profitabilitas merupakan hasil akhir dari berbagai kebijakan dan keputusan. Rasio profitabilitas akan memberikan jawaban tentang manajemen perusahaan dalam menghasilkan keuntungan dari aktiva. 
Profitabilitas menunjukkan kemampuan perusahaan dalam memghasilkan laba selama peride tertentu.

Pengertian kemampulabaan menurut Hanafi $(2003,83)$ dalam bukunya menyatakan bahwa :

"Rasio ini mengukur kemampuan perusahaann menghasilkan keuntungan (profitabilitas) pada tingkat penjualan, asset, dan modal saham yang tertentu".

Pengertian kemampulabaan menurut Margaretha $(2005,21)$ menyatakan bahwa :

"Profitabilitas menunjukkan pengaruh gabungan dari likuiditas, pengelolaan aktiva dan pengelolaan hutang terhadap hasil operasi (laba)".

Pengertian kemampulabaan menurut Gerald I. White etc $(2003,111)$ menyatakan bahwa :

"Profitability analysis : measuresthe income of the firm relative to its revenues and invested capital".

Pengertian kemampulabaan menurut Eugeune F. Brigham dan Michael C. Enrhardt dalam bukunya "Financial Management Theory and Practice" menyatakan bahwa :

"Profitability is the net result of a number of policies and decision. Theratios examined thust forprovide useful clues as to the effectiveness of a firm's operations, but the profitability ratios go on to show the combined effect of liquidity, asset management and debt on operating result."

Sedangkan pengertian kemampulabaan menurut Hirt Block (2002, 2210 dalam bukunya Fundamental of Investment Management menyatakan bahwa :

"Profitability is the analyst to measure the ability of the firm to earn on adequate return on sales, total assets and invested capital". 
Dari pendapat tersebut, penulis memyimpulkan bahwa pada dasarnya kemampulabaan menggambarkan kemampuan perusahaan untuk mendapatkan laba sesuai atau lebih yang diharapkan. Melalui kemampuan - kemampuan perusahaan serta sumber - sumber yang ada seperti kegiatan penjualn dengan menaikkan penjualan, maka akan meningkatkan laba yang diperoleh.

Dalam buku Analisis Laporan Keuangan $(2007,63)$ menyatakan bahwa pada dasarnya ada 2 kategori dasar dalam mengukur kemampulabaan perusahaan, yaitu:

1. Laba dikaitkan dengan penjualan yang biasanya disebut marjin laba (Profit Margin). Hal ini sangat penting untuk mengukur kemampuan perusahaan menciptakan laba dari setiap unit penjualan yang dilakukan. Bila marjin laba perusahaan kecil, maka perusahaan akan mengalami kesulitan untuk menutup beban - beban tetap yang mesti ditanggung serta keuntungan untuk pemegang saham.

2. Laba dikaitkan dengan investasi yang dilakukan oleh kreditor dan pemilik atau pemegang saham. Hal ini biasanya disebut imbal hasil (return). Perusahaan tidak mampu menciptakan laba secara memuaskan kemungkinan terjadi salah urus terhadap sumber daya perusahaan oleh pengelola.

Faktor penting dalam meninjau kemampuan perusahaan menghasilkan laba adalah hubungan level penjualan dengan jumlah sumber daya yang dipergunakan untuk menghasilkan penjualan tersebut.

\subsubsection{Hal - Hal Yang Mempengaruhi Kemampulabaan}

Suatu perusahaan berada dalam kondisi yang sehat atau tidak dapat dilihat dari laba yang dihasilkan. Kemampulabaan suatu perusahaan menggambarkan kondisi keuangan perusahaan tersebut. Perusahaan yang 
mempunyai laba yang maksimal berarti perusahaan tersebut memiliki kemampuan untuk memenuhi kewajiban - kewajiban serta mampu mengelola asset yang dimiliki oleh perusahaan seoptimal mungkin.

Noor Achmad dalam bukunya Analisis Laporan Keuangan (2007, 62) mengatakan bahwa terdapat beberapa hal yang dapat mempengaruhi kemampulabaan, diantaranya adalah :

1. Kegiatan penjualan yaitu dimana barang yang sudah diproduksi oleh perusahaan sudah siap untuk dipasarkan dan digunakan oleh konsumen.

2. Kas adalah segala sesuatu baik yang berbentuk atau bukan yang dapat tersedia dengan segera dan dapat diterima sebagai alat pelunasan kewajiban pada nominalnya. Termasuk sebagai kas adalah rekening giro dan uang kas yang ada di perusahaan.

3. Harta atau asset yang disebut juga aktiva adalah produktif yang dikelola didalam perusahaan tersebut. Harta yang dimiliki perusahaan berperan dalam operasi perusahaan, misalnya : kas, persediaan, aktiva tetap, dan aktiva tidak berwujud.

4. Modal merupakan kumpulan dari semua barang yang ada dalam rumah tangga perusahaan dalam fungsinya produktifitasnya untuk membentuk pendapatan. Jadi yang dimaksud dengan modal bukan hanya berupa uang saja tetapi termasuk juga aktiva yang ada di dalam perusahaan yang digunakan untuk menjalankan operasi usahanya, seperti : mesin - mesin, bangunan pabrik, dan bahan baku.

\subsubsection{Jenis - Jenis Kemampulabaan}

Pada umumnya modal perusahaan berasal dari pemilik perusahaan atau dari kreditur. Dengan adanya 2 jenis modal maka kemampulabaan suatu perusahaan dapat dilihat dengan 2 cara yaitu : 


\section{Rentabilitas Ekonomi}

Merupakan perbandingan antara laba usaha dengan keseluruhan modal, baik modal sendiri maupun modal asing yang dinyatakan dalam persentase.

Oleh karena itu pengertian rentabilitas sering digunakan untuk mengukur efisiensi penggunaan modal dalam suatu perusahaan modal yang diperhitungkan untuk menghitung rentabilitas ekonomi hanya modal yang bekerja dalam perusahaan (Operating Capital). Dengan demikian maka modal lain yang ditanamlkan dalam perusahaan tidak diperhitungkan dalam menghitung rentabilitas ekonomi.

Demikian juga dengan laba yang diperhitungkan dalam rentabilitas ekonomi hanya laba yang berasal dari operasional perusahaan yang disebut dengan Net Operating Income.

Maka rumus yang digunakan untuk mengukur rentabilitas ekonomi adalah :

$$
\text { Re ntabilitas Ekonomi }=\frac{\text { LabaUsaha }}{\text { Modal Asin } g+\text { Modal Sendiri }}
$$

2. Rentabilitas Modal Sendiri

Rentabilitas modal sendiri atau srering dinamakan rentabilitas usaha merupakan perbandingan antara jumlah laba yang tersedia bagi pemilik modal sendiri di satu pihak dengan modal sendiri yang menghasilkan laba di lain pihak.

Laba yang diperhitungkan untuk mengukur tingkat modal sendiri adalah laba usaha setelah dikurangi bunga modal asing dan pajak perseroan atau Income Tax (EAT= Earning After Tax).

Sedangkan modal yang diperhitungkan hanya modal sendiri yang bekerja dalm perusahaan. Rumus rentabilitas usaha adalah:

$$
\text { Re ntabilitasUsaha }=\frac{\text { LabaUsahaSetelahPajdk }(\text { LUSP })}{\text { ModalSendiri }(M S)}
$$




\subsubsection{Peranan Kemampulabaan}

Bagi pemilik perusahaan ketidakmampuan mendapatkan laba dapat menyebabkan terganggunya kegiatan operasional perusahaan. Jika perusahaan tidak dapat berkembang dan tidak mampu dalam menghasilkan laba untuk jangka waktu yang panjang maka akan mengakibatkan kebangkrutan perusahaan tersebut. Hal ini dapat menyebabkan melemahnya kepercayaan investor untuk menanamkan modalnya dan menunjukkan kinerja perusahaan yang kurang baik. Dimana profitabilitas perusahaan merupakan salah satu dasar pertimbangan dalam pengambilan keputusan untuk menolak atau menerima permohonan kredit usaha perusahaan yang bersangkutan.

Rasio kemamapulabaan yang kaitannya dengan penjualan biasa disebut dengan marjin laba, yang dimana memiliki peranan bagi perusahaan, yakni dalam membantu mengukur hubungan antara penjualan dan lab akotor. Apabila marjin laba suatu perusahaan tidak mencukupi, maka perusahaan tidak akan dapat mencapai tingkat pengembalian investor yang diharapkan. Karena marjin laba berperan sebagai indikator kemampuan agen atau manajemen perusahaan dalam menghadapi berbagai kesulitan yang mungkin timbul seperti keadaan jatuhnya hatga- harga dasar di pasaran, terjadi penurunan penjualan atau pada keadaan menguntungkan marjin laba dapat berperan sebagai indikator kemungkinan sukses bagi perusahaan.

Dari uraian yang diungkapkan diatas, penulis dapat memberikan kesimpulan bahwa pentingnya suatu perusahaan untuk menjaga profitabilitasnya agar dapat mempertahankan hidup dan berkembangnya perusahaan tersebut. 


\subsubsection{Ukuran Kemampulabaan}

Ada beberapa pengukuran terhadap profitabilitas perusahaan dimana masing - masing pengukuran dihubungkan dengan volume penjualan, total aktiva, dan modal sendiri. Suatu perusahaan haruslah dalam keadaan menguntungkan atau profitable. Untuk dapat meraih keuntungan atau laba juga harus mampu bekerja secara efisiendan kinerja operasi perusahaan harus senantiasa ditingkatkan.

"Profitabilitas adalah hasil akhirdari keputusan dan kebijakan yang dilakukan oleh perusahaan. Analisis - analisis yang selama ini dibahas dan dibicarakan tentang suatu cara perusahaan dalam beroperasi."

Analisis profitabilitas membicarakan jawaban akhir tentang efektif tidaknya perusahaan. Profitabilitas dapat diukur melalui kemampuan perusahaan mempertahankan kekayaan pemilik (pemegang saham) dalam perusahaan.

Kemampulabaan (profitabilitas) merupakan suatu hasil akhir bersih dari berbagai kebijakan dan suatu keputusan manajemen. Rasio kemapulabaan akan memberi jawaban akhir tentang efektifitas manajemen perusahaan, rasio ini memberi gambaran tentang efektifitas pengelolaan perusahaan.

Menurut Agnes Sawir $(2005,18)$ dalam bukunya Analisis Kinerja Keuangan dan Perencanaan Keuangan Perusahaan, menyatakan bahwa rasio kemampulabaan yang umum digunakan adalah :

\section{Margin Laba Kotor (Gross Profit Margin)}

Gross Profit Margin (GPM) menghubungkan penjualan dengan laba kotor. Rasio ini mengukur efisiensi pengendalian harga pokok atau biaya produknya, mengindiaksikan kemampuan perusahaan untuk berproduksi secara efisien. Rasio ini penting untuk menilai tingkat efisiensi di pabrik. Margin Laba Kotor (GPM) dalam paratik merupakan tanggung jawab manajer produksi. Dari waktu ke waktu GPM diukur untuk menilai apakah 
produksi telah dilakukan sesuai dengan normastandar yang ditetapkan. Angka GPM dari waktu ke waktujuga dapat menggambarkan apakah produksi dilaksanakansemakin efisien atau tidak, atau tetap sesuai dengan standar yang berlaku. Semakin tinggi angka rasio ini berarti semakin efisien produksi yang dilakukandan semakin tinggi dayasaing perusahaan. Ketentuan ini didasrkan pada logikabahwa secaranormatif laba kotor diperoleh dari nilai penjualan dikurangi dengan harga pokok penjualan/pabrik, sehingga semakin besarnya laba disebabkan oleh semakin kecilnya harga pokok. Semakin kecil harga pokok merupakan refleksi dari semakin efisiennya aktivitas produksi. Rumus dari margin laba kotor atau Gross Profit Margin (GPM) adalah :

$$
\text { GrossProfit } M \text { arg in }=\frac{\text { Sales }- \text { Cost of Good Sold }}{\text { Sales }}
$$

Atau

$$
\text { Marjin Laba Kotor }=\frac{\text { Penjualan }-H P P}{\text { Penjualan }}
$$

\section{Marjin Laba Bersih (Net Profit Margin/Profit Margin On Sales)}

Rasio ini mengukur laba bersih setelahpajak terhadap penjualan. Secara teoritis laba bersih (EarningAfterTax/EAT) adalah dihitung dengan menggunakan formula : EAT= EBIT - Beban Bunga - Pajak.

Akan tetapi dalam praktik masih harus ditambah dan dikurangi lagi dengan pendapatan dan beban diluar usaha yang kadang - kadang memberikan indikator yang berbeda. Kadang perusahaan yang secara operasional menghasilkan laba akan tetapi mengalami rugi bersih dan sebaliknya. Oleh karena itu dalam analisis kemampulabaan sering faktor pendapatan dan beban diluar usaha tidakdiperhitungkan. Akan tetapi laba bersih secara teori dijadikan tolok ukur 'earning power' perusahaan bila dikaitkan dengan total 
investasi. Sementaraitu EBIT terhadap total investasi dijadikan sebagai ukuran 'basic earning power'.

Rumus dari marjin laba bersih atau Net Profit Margin/Profit Margin On Sales adalah :

$$
\text { Net } \operatorname{Pr} \text { ofit } M \text { arg in }=\frac{\text { Net Income }}{\text { Sales }}
$$

Atau

$$
\text { Marjin Laba Bersih }=\frac{\text { Laba Bersih }}{\text { Penjualan }}
$$

Rumus dari Daya Laba Dasar (Basic Earning Power) / Rentabilitas Ekonomi adalah :

$$
\text { BasicEarningPower }=\frac{\text { EBIT }}{\text { Total Assets }}
$$

Atau

$$
\text { Daya Laba Dasar }=\frac{\text { Laba SebelumBunga\& Pajak }}{\text { Total Aktiva }}
$$

Daya dasar laba mencoba mengukur efektifitas perusahaan dalam memanfatkan seluruh sumber dayanya, yang menunjukkan rentabilitas ekonomis perusahaan. Tinggi rendahnya rentabilitas ekonomi tergantung dari :

\section{Operating Profit Margin (Marjin Laba Operasi)}

Laba operasi (operating profit) atau pada umumnya sering disebut EBIT. OPM menghubungkan laba operasi atau EBIT dengan penjualan. Laba operasi merefleksikan kemampulabaan operasional dan dijadikan dasar dalam pengambilan keputusan keuangan.

$$
\text { Operating Profit } M \text { arg in }=\frac{E B I T}{\text { Sales }}
$$




$$
\begin{gathered}
\text { Atau } \\
M \arg \text { in Laba Operasi }=\frac{\text { Laba SebelumBunga \& Pajak }}{\text { Penjualan }}
\end{gathered}
$$

\section{Net Earning Power Ratio}

Rasio ini dikenal dengan nama Return on Asset Ratio (ROA). Rasio mengukur pengembalian atar total aktiva setelah bunga dan pajak. Hasil pengembalian total aktiva atau total investasi menunjukkan kinerja manajemen dalam menggunakan aktiva perusahaan dalam menghasilkan laba. Perusahaan mengharapkan adanya hasil pengembaliam yang sebanding dengan dana yang digunakan. Hasil pengembalian ini dapat dibandingkan dengan penggunaan alternatif dari dana tersebut. Sebagai salah satu ukuran ke efektifan, maka semakin tinggi hasil pengembalian semakin efektiflah perusahaan. Adapun rumus yang digunakan adalah :

$$
\begin{gathered}
\text { ROA }=\frac{\text { Laba Bersih Setelah Pajak }}{\text { Total Aktiva }} \\
\text { Atau } \\
\text { Return On Assets }=\frac{\text { Net Income }}{\text { Total Assets }}
\end{gathered}
$$

3. Return on Equity (ROE)

Rasio ini menunjukkan keberhasilan atau kegagalan pihak manajemen dalam memaksimalkan tingkat hasil pengembalian investasi pemegang saham dan menekankan pada hasil pendapatan sehubungan dengan jumlah yang diinvestasikan. Rasio ini mengukur tingkat pengembalian atas investasi pemegang saham. Adapun rumus yang digunakan adalah :

$$
R O E=\frac{\text { Laba Bersih Setelah Pajak }}{\text { Ekuitas }}
$$

\subsubsection{Pertumbuhan Perusahaan}


Dalam penelitian ini pertumbuhan perusahaan diproksikan dengan rasio pertumbuhan penjualan. Sales growth ratio atau rasio pertumbuhan penjualan mengukur seberapa baik perusahaan mempertahankan posisi ekonominya, baik dalam industrinya maupun dalam kegiatan ekonomi secara keseluruhan.

Pertumbuhan penjualan menunjukkan kemampuan perusahaan untuk dapat bertahan dalam kondisi persaingan. Pertumbuhan penjualan lebih tinggi dibandingkan dengan kenaikan biaya akan mengakibatkan kenaikan laba perusahaan. Jumlah laba yang diperoleh secara teratur serta kecenderungan atau trend keuntungan yang meningkat merupakan suatu faktor yang sangat menentukan perusahaan untuk tetap bertahan. Sementara perusahaan dengan rasio pertumbuhan penjualan negatif berpotensi besar mengalami penurunan laba sehingga apabila manajemen tidak segera mengambil tindakan perbaikan, perusahaan dimungkinkan tidak akan dapat mempertahankan kelangsungan hidupnya.

Penjualan merupakan kegiatan operasi utama perusahaan. Perusahaan yang mempunyai rasio pertumbuhan penjualan positif mengindikasikan bahwa perusahaan dapat memepertahankan kelangsungan hidupnya. Penjualan yang terus meningkat dari tahun ke tahun akan memberikan peluang perusahaan untuk memperoleh peningkatan laba.

Menurut Fabozzi $(2000,881)$, pertumbuhan penjualan merupakan perubahan pada laporan keuangan pertahun. Pertumbuhan penjualan yang diatas rata - rata suatu perusahaan pada umumnya didasarkan pada pertumbuhan yang cepat yang diharapkan pada pertumbuhan yangcepat diharapkan dari industri dimana perusahaan itu beroperasi. Perusahaan dapat mencapai tingkat pertumbuhan diatas rata - rata dengan jalan meningkatkan pangsa pasar dari permintaan indsutri keseluruhan. 
Analisis dalam menghitung pertumbuhan penjualan dilakukan dengan menghitung tingkat pertumbuhan tahun majemuk pada saat mempelajari trend jangka panjang dalam hal penjualan. Tingkat pertumbuhan majemuk merupakan tingkat yang jika diterapkan setiap tahun selama kurun waktu tertentu pada saldo awal akan menyebabkan neraca berkembang sehingga mencapai nilai akhir yang maksimal. Peningkatan pangsa pasar harus sejalan dengan strategi pemasaran yang tepat dan perusahaan selalu melakukan inovasi, hal ini bermakna bahwa dengan startegi yang tepat dapat meningkatkan pertumbuahn penjualan melalui pengembangan produk yang diminati konsumen.

Pertumbuhan penjualan dapat dirumuskan sebagai berikut :

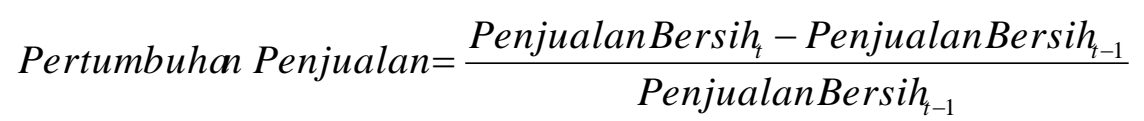

Dimana :

Penjulan Bersih $\mathrm{t}_{\mathrm{t}} \quad=$ Penjualan bersih sekarang

Penjualan Bersih $_{\mathrm{t}-1}=$ Penjualan bersih tahun lalu

\subsection{Kerangka Pemikiran Konseptual}

Perusahaan merupakan sebuah organisasi yang mempunyai kepentingan - kepentingan tertentu di dalam menjalankan kegiatan usahanya. Kepentingan tersebut ada di dalam perusahaan didasarkan pada kebutuhan dari setiap individu yang tergabung di dalam pendirian suatu organisasi. Setiap individu yang tergabung didalam pendirian suatu perusahaan dapat dikatakan sebagai investor, baik investor yang berasal dari pihak internal maupun dari pihak eksternal yaitu masyarakat. Investor dari pihak eksternal baru dapat dikatakan sebagai individu yang tergabung di dalam suatu perusahaan ketika membeli saham yang diperdagangkan oleh perusahaan tersebut setelah perusahaan 
tersebut menjadi perusahaan terbuka. Investor eksternal turut membantu di dalam pemberian modal yang membantu perusahaan tersebut untuk tetap menjalankan kegiatan usahanya.

Sebagai seorang investor tentunya menginginkan pengembalian atas apa yang sudah ditanamkan pada perusahaan tersebut yang biasanya disebut sebagai dividen. Untuk memenuhi keinginan tersebut maka perusahaan membentuk manajemen keuangan perusahaan yang mempunyai tugas utama untuk memaksimalkan kekayaan para pemegang saham. Agar dapat memaksimalkan kekayaan pemegang saham, maka manajemen harus menjaga kegiatan operasional perusahaan untuk kelangsungan hidup perusahaan, dimana manajemen masih dapat memenuhi kewajibannya kepada para pemegang saham.

Untuk dapat terjaganya kegiatan operasional manajemen harus mengontrol pengeluaran kas dan penerimaan kas, karena di dalam kegiatan operasional tidak dapat dipisahkan dari penerimaan dan pengeluaran biaya - biaya selama kegiatan operasional berlangsung. Resume dari semua penerimaan dan pengeluaran kas dapat dilihat pada laporan keuangan yang terdapat pada laporan arus kas. Laporan arus kas memperlihatkan kemana saja pengeluaran terjadi dan dari mana saja perusahaan mendapatkan pendapatannya, dari laporan arus kas tersebut perusahaan dapat melihat perkembangan arus kas bersih dari aktivitas operasi dari waktu ke waktu.

Hasil yang diterima dari arus kas operasi dapat memperlihatkan kemampuan perusahaan didalam meningkatkan kemampulabaan. Semakin besar arus kas operasi yang dihasilkan menunjukkan bahwa perusahaan tersebut mampu mengelola sumber daya yang dimiliki oleh perusahaan dengan baik dan kemampuan perusahaan dalam menghasilkan laba atau kemampulabaan perusahaan dapat dilihat antara penerimaan dari penjualan dan 
pengeluaran biaya - biaya yang dihasilkan selama kegiatan opearsional dari penggunaan aktiva tetap maupun aktiva lancar dalam kegiatan memproduksi barang.

Arus kas bersih dari aktivitas operasi dapat menjadi tambahan modal bagi perusahaan dalam bentuk kas. Dimana jika kas bertambah, maka perusahaan dapat meningkatkan kegiatan produksinya seiring dengan bertambahnya modal perusahaan dapat meningkatkan pembelian bahan baku untuk proses produksi. Jika proses produksi dapat meningkat diharapkan penjualan pun dapat ditingkatkan dari waktu ke waktu, sehingga perusahaan dapat mengalami pertumbuhan dari segi penjualannya.

Tujuan Manajemen

Keuangan 


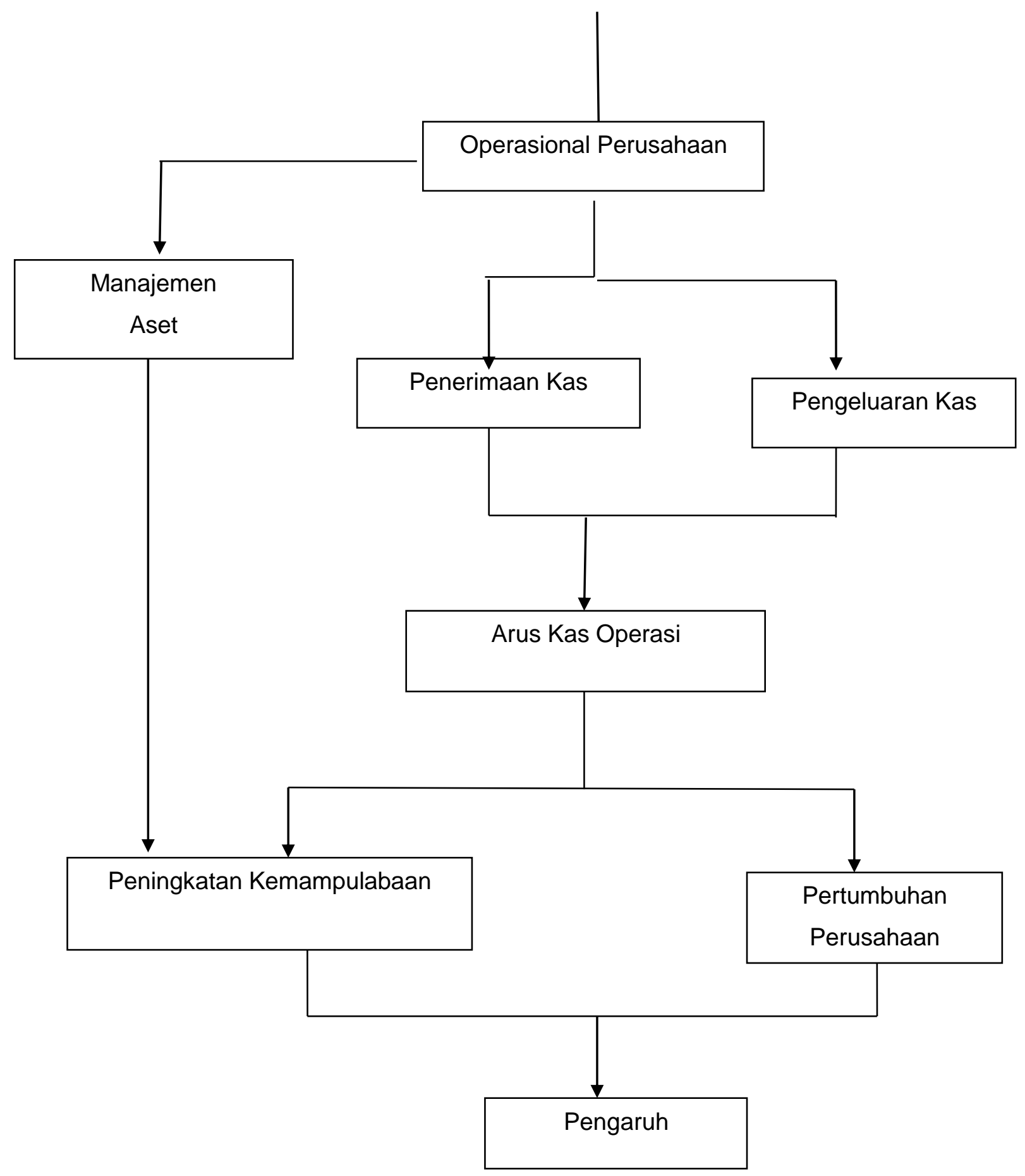

Gambar 2.1

Kerangka Pemikiran Konseptual

\subsection{Prremis dan Hipotesis}

\subsubsection{Premis}


Premis adalah sesuatu yang dianggap benar, sebagai keputusan yang diterima sebagai suatu kebenaran.

\section{Premis 1}

Profitabilitas perusahaan pada perusahaan - perusahaan manufaktur go public di Bursa Efek Indonesia yang mengalami peningkatan dapat dijadikan indikasi adanya peluang bisnis yang baik sehingga perusahaan terdorong untuk meningkatkan investasinya. Dengan demikian dapat disimpulkan bahwa profitabilitas perusahaan mempengaruhi secara signifikant keputusan invesasi oleh manajemendan hubungan antara keduanya adalah positif (Wahyuningsih : 1998).

\section{Premis 2}

Perolehan Pertumbuhan Perusahaan (growth) sebagai hasil pengolahan data penjualan dan profitabilitas pada kedua sampel perusahaan secara keseluruhan mengalami peningkatan yang dipengaruhi oleh salah satu atau kedua faktor penentu (growth) yaitu penjualan dan profitabilitas. (Ronald Kamage, Pengaruh Penjualan dan Profitabilitas Terhadap Pertumbuhan Perusahaan, 2008)

\subsubsection{Hipotesis}

\subsubsection{Hipotesis Penelitian}

Dari uraian diatas dapat diambil kesimpulan sementara melalui hipotesis penelitian berdasarkan klasifikasi masalah adalah sebagai berikut :

1. Arus kas operasi dan Manajemen Aset mempunyai hubungan yang positif dan signifikan dengan peningkatan kemampulabaan.

2. Arus kas operasi dan manajemen aset mempunyai hubungan yang negatif dengan pertumbuhan perusahaan.

\subsubsection{Hipotesis Stasistik}


1. Hipotesis statistik berdasarkan perhitungan koefesien korelasi.

Ho : $R=0$ Arus kas operasi dan manajemen aset tidak berkorelasi terhadap peningkatan kemampulabaan.

$\mathrm{Ha}: \mathrm{R} \neq 0$ Arus kas operasi dan manajemen aset berkorelasi terhadap pertumbuhan perusahaan.

2. Hipotesis statistik berdasarkan perhitungan koefesien determinasi.

Ho : $R^{2}=0$ Arus kas operasi dan manajemen aset tidak memilik kedekatan hubungan terhadap peningkatan kemampulabaan.

$\mathrm{Ha}: \mathrm{R}^{2} \neq 0 \quad$ Arus kas operasi dan manajemen aset memiliki kedekatan hubungan terhadap pertumbuhan perusahaan.

3. Hipotesis statistik berdasarkan perhitungan korelasi regresi.

Ho : $\beta=0 \quad$ Arus kas operasi dan manajemen aset tidak memiliki pengaruh terhadap peningkatan.

$\mathrm{Ha}: \beta \neq 0$ Arus kas operasi dan manajemen aset berpengaruh terhadap pertumbuhan perusahaan.

Uji anova atau $f$ dengan tingkat signifikant $=5 \%$, Ho akan ditolak dan menerima Ha apabila signifikant $\leq 5 \%$, apabila signifikant $\geq 5 \%$ maka Ho akan diterima dan Ha. Ho akan diterima berarti ada variabel lain yang mempengaruhi.

Uji t dengan tingkat signifikant $=5 \%$, apabila $\mathrm{t}$ nitung $<\mathrm{t}$ tabel, Ho diterima dan apabila $t$ hitung $>t$ tabel, Ho ditolak. Ho diterima berarti ada variabel lain yang mempengaruhi.

\section{BAB III}

\section{METODOLOGI PENELITIAN}




\subsection{Sejarah Perusahaan}

Sejarah adalah sumber dari pengetahuan, oleh karena itu penulis perlu untuk mengungkap sejarah singkat dari ketiga obyek penelitian yang diambil yaitu PT. Indocement Tunggal Prakarsa, Tbk (INTP) dan PT. Semen Gresik (Persero), Tbk (PT. SMGR) untuk mengetahui asal - usul, perkembangan dan pertumbuhan dari ketiga perusahaan tersebut ini dimulai dari awal dididrikannya perusahaan tersebut.

\subsubsection{PT. Indocement Tunggal Prakarsa, Tbk}

Indocement adalah salah satu produsen semen terbesar di Indonesia yang memproduksi berbagai jenis semen bermutu, termasuk produk semen khusus. Perseroan didirikan pada thaun 1985 dan mengoperasikan unit produksi terpadu dengan total kapasitas produksi sebesar 16, 5 juta ton semen per tahun. Pada saat ini perseroan mengoperasikan 12 pabrik, sembilan diantaranya berlokasi di Citereup, Bogor, Jawa Barat, dua di Palimanan, Cirebon, Jawa Barat dan satu di Tarjun, Kotabaru, Kalimantan Selatan.

Sejak tahun 2005, perseroan telah melakukan diversifikasi produk dengan meluncurkan Semen Portland Komposit (Portland Composite Cement/PCC). Perseroan juga memproduksi berbagai jenis semen lainnya, yaitu Semen Portland Tipe I, Tipe V,Semen Sumur Minyak (Oil Well Cement) dan Semen Putih (White Cement). Indocement saat ini merupakan satu - satunya produsen Semen Putih di Indonesia. Produk perseroan dipasarkan dengan merek dagang "Tiga Roda".

Pada tahun 2001, Heidelberg Cement Group, salah satu produsen semen terkemuka di dunia yang berpusat di Jerman dan beroperasi di 50 negara,menjadi pemegang saham mayoritas di perseroan. Sejak itu, perseroan 
bertekad unutk memulihkan kondisi keuangan yang sehat seperti sebelum terjadinya krisis keuangan Asia. Dengan dukungan Heidelberg Cement Group Indocement kembali memfokuskan kegiatannyadi bisnis inti sebagai produsen semen, dengan tujuan untuk mencapai kondisi keuangan yang sehat. Sasaran ini telah tercapaii dengan diselesaikannya seluruh kewajiban Indocement atas Master Facilities Agreement (MFA) pada tahun 2006.

Dengan kondisi keuangan yang kembali sehat, Perseroan siap mengambil langkah - langkah investasi untuk mengimbangi pertumbuhan pasar semen Indonesia.

Pada tahun 2007, indocement menyelesaikan program peremajaan Pabrik ke -8 di Citereup yang memberikan Perseroan tambahan kapasitas produksi semen sebesar600.000 ton semen per tahun.

Sebagai bagian dari program Tanggung Jawab Sosial dari Lingkungan Perusahaan, Indocement berhasil mengembangkan perkebunan tanaman jarak seluas 30 hektar di area bekas penambangan batu kapur, Indocement juga berhasil menfasilitasi program pengumpulan sampah dari masyarakat. Hasil pengumpulan sampah ini diolah menjadi bahan bakar biomassa untuk proses pembakaran dalam produksi semen, dan kompos.

Setelah berupaya keras selama empat tahun mulai Desember 2002, United Nations Framework Convention on Climate Change (UNFCC) telah melakukan registrasi atas dua proyek Indocement dalam kerangka Mekanisme Pembangunan Bersih (Clean Development Mechanism), yaitu proyek bahan bakar alternatifdan proyek Blended Cement. Hingga pada tahun 2008, perusahaan dan anak perusahaannya memperkerjakan mencapai lebih dari 6.000 personil. 


\section{Visi, Misi dan Moto PT. Indocement Tunggak Prakarsa, Tbk (INTP)}

Visi

Pemimpin pasar semen dalam negeri yang berkualitas

Misi

Kami berkecimpung dalam bisnis penyediaan papan, bahan bangunan dan jasa terkait yang bermutu dengan harga kompetitif dan tetap memperhatikan pembangunan berkelanjutan.

Moto

Turut membangun kehidupan bermutu.

\section{Sejarah Singkat PT. Indocement Tunggal Prakarsa, Tbk}

Tahun 1985

1. PT. Indocement Tunggal Prakarsa didirikan melalui penggabungan usaha enam perusahaan yang memiliki delapan pabrik semen.

Tahun1986

2. Indocement menjadi perusahaan publik dan mencatatkan sahamnya di Bursa Efek Indonesia (dahulu Bursa Efek Jakarta dan Bursa Efek Surabaya).

Tahun 1991

3. Perseroan mengakuisisi pabrik ke -3 di Palimanan, Cirebon, Jawa Barat yang memiliki kapasitas terpasang 1,3 juta ton semen per tahun.

4. Penyelesaian pembangunan Terminal Semen Surabaya.

5. Memulai usaha Beton Siap - Pakai.

Tahun 1996

6. Pabrik ke - 10 di Palimanan, Cirebon, Jawa Barat selesai dibangun dengan kapasitas terpasang 1,3 juta ton semen per tahun.

Tahun 1999 
7. Pabrik ke - 11 di Citereup, Bogor, Jawa Barat selesai dibangun dengan kapasitas terpasang 2,6 juta ton semen per tahun.

Tahun 2000

8. Pengambil alihan PT. Indo Kodeco Cement melalui penggabungan usaha (pabrik ke - 12) dengan kapasitas terpasang 2,6 juta ton semen per tahun.

Tahun 2001

9. Heidelberg Cement Group menjadi pemegang saham mayoritas melalui anak perusahaannya Kimmerdge Enterprise Pte. Ltd .

Tahun 2002

10. Penyelesaian instalasi alat Penangkap Debu Elektrostatik (Electrostatic Precipator) di Pabrik Citereup dan Cirebon.

11. Menjadi pemegang saham pengendali di PT. Pionirbeton Industri.

Tahun 2003

12. Menerima penghargaan Superbrands 2003/2004 dari Superbrands Organization, Inggris.

13. Kompleks Pabrik Citereup meraik Peringkat Hijau dari Kementrian Lingkungan Hidup Republik Indonesia sebagai hasil Program Penilaian Peringkat Kinerja Perusahaan dalam Pengelolaan Lingkungan (PROPER)

Tahun 2005

14. Meluncurkan produk Semen Portland Komposit (Portland Composite Cement/PCC) ke pasaran Indonesia.

15. Kompleks Pabrik Citereup meraik Peringkat Hijau dari Kementrian Lingkungan Hidup Republik Indonesia sebagai hasil Program Penilaian Peringkat Kinerja Perusahaan dalam Pengelolaan Lingkungan (PROPER)

16. Penggabungan perusahaan $\mathrm{HC}$ Indocement $\mathrm{GmbH}$ dengan Heidelberg Cement South East Asia $\mathrm{GmbH}$, dimana yang disebutkan terakhir menjadi 
perusahaan yang dipertahankan dan pemegang saham langsung dari Indocement.

Tahun 2006

17. Melakukan pembiayaan kembali untuk menggantikan Master Facilities Agreement.

18. Menerima penghargaan IMAC (Indonesian Most Admired Companies) 2006 untuk pengembangan citra perusahaan terbaik dalam kategori industri semen.

19. Heidelberg Cement South - East Asia $\mathrm{GmbH}$, pemegang saham langsung Indocement bergabung dengan HeidelbergCement AG, yang menguasai 65, $14 \%$ saham Indocement.

20. Indocement menerima Penghargaan AIDS kategori perak dari Komisi Nasional Peduli AIDS atas upaya dan prestasinya melaksanakan program penaggulangan HIV dan AIDS di tempat kerja.

21. The United Nations Framework Convention on Climate Change (UNFCC) telah melakukan registrasi Proyek Bahan Bakar Alternatif Indocement pada 29 September dan Proyek Blended Cement pada 27 Oktober dalam rangka penerbitan Pengurangan Emisi Karbon (Certified Emission Reduction/CER) yang jumlahnya akan diverifikasi oleh pihak independen.

Tahun 2007

22. Bendera Emas.

Pada tanggal 2 Januari, Indocement menerima penghargaan Bendera Emas, atas kinerjanya di bidang Kesehtan dan Keselamatan Kerja untuk ketiga lokasi pebriknya dari Menteri Tenaga Kerja.

23. SGS Quality Award.

Pada tanggal 21 Mei, Indocement menerima SGS Quality Award atas upaya melakukan inovasi berupa penggunaan material alternatif. 
24. The Best Chief Financial Officer 2007.

Pada tanggal 11 Juli, Christian Kartawijaya Direktur Indocement menerima penghargaan The Best Chief Financial Officer dari Majalah Finance Asia, Hongkong.

25. The Ten Best Managed Companies

Pada tanggal 11 Juli Indocement menerima penghargaan The Ten Best Managed Companies dari Majalah Finance Asia, Hongkong.

26. IMAC Award.

Pada tanggal 18 Juli Indocement menerima penghargaan IMAC (Indonesia Most Admired Companies) 2007, untuk pengembangan citra perusahaan terbaik dalam kategori semen dari industri Business week dan Frontier Consulting Group.

27. Proyek Perkebunan Tanaman Jarak.

Pada tanggal 20 Juli Indocement mulai melakukan sosialitas proyek percontohan perkebunan pohon jarak sebagai bahan bakar alternatif.

28. Bina Lingkungan.

Pada tanggal 23 Juli Indocement meresmikan gedung SMA Indocement, yang berlokasi di Citereup Bogor.

29. Akuisisi PT. Gunung Tua Mandiri.

Pada tanggal 25 Juli Indocement membeli 51\% saham PT. Gunung Tua Mandiri, sebuah perusahaan tambang agregat yang terletak di Rumpin, Jawa Barat.

30. Bina Lingkungan.

Pada tanggal 1 Agustus Indocement melakukan serah terima SMP Negeri 1 Gempol, Cirebon kepada Dinas Pendidikan Kabupaten Cirebon.

31. Business Review Awards. 
Pada tanggal 15 Agustus Indocement menerima penghargaan untuk beberapa ketegori dari Majalah Business Review.

32. Top Brand 2007.

Pada tanggal 22 Agustus Indocement menerima penghargaan Top Brand 2007 dari Frontier Consulting Group dari Majalah Marketing.

33. Gugus Kendali Mutu (GKM).

Pada tanggal 27 November GKM Indocement meraih 2 medali emas dan 3 medali perak dalam Konvensi Mutu Indonesia 2007.

34. SWA 100 Award.

Pada tanggal 17 Desember Indocement menerima penghargaan yangdiberikan oleh Majalah SWA serta stem Steward \& Co sebagai 100 perusahaan Pencipta Nilai Terbaik di Indonesia pada tahun 2007.

Tahun 2008.

35. Clean Development Mechanism Framework.

United Nations Framework Convention on Climate Change (UNFCC) menerbitkan Certified Emission Reduction terkait dengan : Proyek Bahan Bakar Alternatif yang dilakukan oleh Indocement, pada tanggal 24 dan 27 Maret 2008. Indocement menjadi perusahaan pertama di Indonesia yang sukses menyelesaikan Clean Development Mechanism Framework.

36. Restrukturisasi Internal HeidelbergCement Group.

Sehubungan dengan restrukturisasi internal HeidelbergCement Group, pada 28 November 2008, HeidelbergCement AG (Jerman) pemegang saham utama Indocement mengalihkan seluruh kepemilikan sahamnya di Indocement sebanyak 2.397 .980 .863 saham $(65,14 \%$ dari seluruh saham Indocement) kepadaBirchwood Omnia Limited (Inggris). Pengalihan saham tersebut tidak mengubah pihak pengendali Indocement, karena Birchwood Omnia Limited dimiliki oleh HeidelbergCement Group. 


\subsubsection{PT. Semen Gresik (Persero), Tbk}

PT. Semen Gresik (Persero), Tbk merupakan perusahaan yang bergerak di bidang industri semen. Diresmikan di Gresik pada tanggal 7 Agustus 1957 oleh Presiden RI pertama dengan kapasitas terpasang 250.000 ton semen per tahun. Pada tanggal 8 Juli 1991 Semen Gresik tercatat di Bursa Efek Jakarta dan Bursa Efek Surabaya serta merupakan BUMN pertama yang go public dengan menjual 40 juta lembar saham kepada masyarakat. Komposisi pemegang sahamnya adalah Negara RI 73\% dan masyarakat $27 \%$.

Pada bulan September 1995 Perseroan melakukan Penawaran Umum Terbatas (Right Issue I) yang mengubah komposisi kepemilikan saham menjadi Negara RI 65\% dan masyarakat 35\%. Tanggal 15 September 1995 PT. Semen Gresik berkonsolidasi dengan PT. Semen Padang dan PT. Semen Tonasa kemudian dikenal dengan nama Semen Gresik Group (SGG). Total kapasitas yang terpasang SGG sebesar 8.5 juta ton semen per tahun. Pada tanggal 17 September 1998 Pemerintah melepas kepemilikan sahamnya di SGG sebesar $14 \%$ melalui penawaran terbuka yang dimenangkan oleh Cemex SA de CV perusahaan semen global yang berpusat di Mexico. Komposisi kepemilikan saham kembali menjadi Negara RI 51\% masyarakat 35\% dan Cemex 14\%. Pada tanggal 30 September 1999, komposisi kepemilikan saham kembali berubah menjadi Negara RI 51\%, masyarakat 23, 5\% dan Cemex 25, 5\%

Pada tanggal 27 Juli 2006 terjadi transaksi penjualan saham Cemex SA de CV pada Blue valley Holdings PTE Ltd, sehingga komposisi kepemilikan saham sampai saat ini berubah menjadi Negara RI 51, 01\% dan masyarakat 24, 09\%. Kapasitas terpasang riil SGG sebesar 16.92 juta ton semen per tahun dan mengusai $46 \%$ pangsa pasar semen domestic.

Pada tahun 1991 PT. Semen Gresik (Persero), Tbk merupakan Badan Usaha Milik Negara (BUMN) yang pertana menjual sahamnya kepada 
masyarakat (go public) dengan melakukan penawaran umum atas 40.000 .000 saham biasa atas nama dengan nilai nominal Rp. 1.000 setiap saham dengan harga penawaran Rp. 7.000 setiap saham. Dana hasil Penawaran Umum seluruhnya untuk membiayai sebagian kebutuhan dana pembagunan semen baru di Tuban Jawa Timur, dengan kapasitas terpasang 2, 3 juta ton semen per tahun dan untuk Proyek Optimalisasi Pabrik II Gresik untuk meningkatkan kapasitas dari 1 juta ton semen per tahun menjadi 1, 3 juta ton per tahun serta meningkatkan efisiensi pemakaian tenaga listrik dan bahan bakar.

\section{Visi dan Misi PT. Semen Gresik (Persero), Tbk}

\section{Visi}

Menjadi perusahaan persemenan bertaraf international yang terkemuka dan mampu meningkatkan nilai tambah kepada para pemangku kepentingan (stakeholders).

\section{Misi}

a. Memproduksi, memperdagangkan semen dan produk terkait lainnya yang berorientasikan kepuasan konsumen dengan menggunakan teknologi yang ramah lingkungan.

b. Mewujudkan manajemen perusahaan yang berstandar internasional dengan menjunjung tinggi etika bisnis, semangat kebersamaan, dan bertindak proaktif, efisien serta inofatif dalam berkarya.

c. Memiliki keunggulan bersaing dalam pasar semen domestik dan internasional.

d. Memberdayakan dan mensinergikan unit - unit usaha strategic untuk meningkatkan nilai tambah secara berkesinambungan. 
e. Memiliki komitmen terhadap peningkatan kesejahteraan pemangku kepentingan (stakeholders) terutama pemegang saham, karyawan dan masyarakat sekitarnya..

\subsection{Uraian Tugas}

\subsubsection{PT. Indocement Tunggal Prakarsa, Tbk}

Tabel 3.1

Uraian Tugas PT. Indocement Tunggal Prakarsa, Tbk

\begin{tabular}{|l|l|}
\hline \multicolumn{1}{|c|}{ Jabatan } & \multicolumn{1}{|c|}{ Nama } \\
\hline Komisaris Utama/Komisaris Independen & DR. Albert Sceheuer \\
\hline Wakil Komisaris Utama/Komisaris Independen & Sudwikantmono \\
\hline Wakil Komisaris Utama/Komisaris Independen & I Nyoman Tjager \\
\hline Komisaris Independen & Sri Prakarsh \\
\hline Komisaris & Dr. Lorenz Naeger \\
\hline Komisaris & DR. Bernhard Scheifele \\
\hline Komisaris & Daniel hugues Jules Gauthier \\
\hline Direktur Utama & Daniel Eugene Antonie Lavalle \\
\hline Wakil Direktur Utama & Tedy Djugar \\
\hline Direktur & Hasan Imer \\
\hline Direktur & Nelson G. D. Borch \\
\hline Direktur & Christian Kartawijaya \\
\hline Direktur & Kuky Permana Kumalaputra \\
\hline Direktur & Ernest Gerard \\
\hline Direktur & \\
\hline
\end{tabular}

\subsubsection{PT. Semen Gresik (Persero), Tbk}

Tabel 3.2

Uraian Tugas PT. Semen Gresik (Persero), Tbk 


\begin{tabular}{|l|l|}
\hline \multicolumn{1}{|c|}{ Jabatan } & \multicolumn{1}{|c|}{ Nama } \\
\hline Komisaris Utama & Dedi Aditya Sumanagara \\
\hline Wakil Komisaris Utama & Darjoto Setyawan \\
\hline Komisaris & Setia Purwaka \\
\hline Komisaris Independen & Marwoto Hadi Soesatro \\
\hline Komisaris Independen & Arif Arryman \\
\hline Komisaris Independen & Achmad Jazidie \\
\hline Direktur Utama & Dwi Soetjipto \\
\hline Wakil Direktur Utama & Navin Sonthalia \\
\hline Direktur Keuangan & Cholil Hasan \\
\hline Direktur Litbang Dan Operasional & Suharto \\
\hline Direktur Pemasaran & Irwan Suarly \\
\hline Direktur Produksi & Suparni \\
\hline
\end{tabular}

\subsection{Lokasi dan Waktu Penelitian}

Dalam proses penyusunan skripsi ini, penulis melakukan penelitian dengan mengambil data sekunder yaitu sumber data penelitian yang diperoleh penuli secara tidak langsung melalui media perantara (diperoleh dan dicatat oleh pihak lain) atau melakukan penelitian tidak langsung dari sumber aslinya. Penulis mengambil data sekunder objek penelitian melalui media internet dan BEI STIE Kesatuan. Penulis melakukan penelitian sejak tanggal 14 Juni sampai dengan 14 Juli 2012.

Adapun waktu pengambilan data sekunder dari kedua perusahaan tersebut yang akan penulis teliti : 
1. Tanggal 10 Juni 2012 penulis membeli data perusahaan di Pojok BEI yang berada di STIE Kesatuan.

2. Tanggal 20 Juni 2012 penulis melakukan browsing internet dengan situs www.google.com untuk mencari data company profile (sejarah perusahaan)

\subsection{Metode Penelitian}

Dalam suatu penulisan diperlukan data dan informasi yang lengkap dan tepat yang berfungsi untuk mendukung hasil penelitian, oleh karena itu dalam penulisan skripsi ini penulis mengumpulkan data dan informasi yang dapat mendukung dan relevan dengan judul penulisan. Data dan informasi yang dikumpulkan kemudian dianalisis agar memperoleh hasil yang diinginkan.

Metode penelitian yang digunakan adalah metode deskriptif komparatif, yaitu suatu metode yang dilakukan dengan cara mencari data yang dapat memberikan gambaran yang jelas tentang PT. Indocement Tunggal Prakarsa, Tbk dan PT. Semen Gresik, Tbk. Kemudian penulis bermaksud untuk membandingkan perkembangan peningkatan kemampulabaan dan pertumbuhan perusahaan tiap tahun dalam periode 5 tahun terakhir. Metode ini tersusun sebagai berikut :

1. Studi Deskriptif

Yaitu studi yang dilakukan dengan cara menguraikan dan menjelaskan mengenai arus kas operasi, peningkatan kemampulabaan dan pertumbuhan perusahaan sebagai variabel penelitian.

\section{Analisis Rasio}

Yaitu merupakan suatu metode analisis atas laporan keuangan (neraca, laba rugi dan arus kas) dengan membandingkan pos - pos yang ada dalam laporan keuangan PT. Indocemet Tunggal Prakarsa, Tbk dan PT. Semen 
Gresik (Persero), Tbk sehingga diketahui hubungan secara individu atau kombinasi dari kedua laporan tersebut.

\subsection{Operasionalisasi Variabel}

Untuk memudahkan proses analisis, penulis terlebih dahulu membagi variabel - variabel penelitian kedalam dua kelompok, yaitu :

1. Variabel Independen (Variabel Tidak Terikat atau Bebas)

Variabel independen adalah variabel yang dapat mempengaruhi variabel dependen. Dalam skripsi ini variabel independen adalah arus kas operasi (X)

2. Variabel Dependen (Variabel Terikat atau Tidak Bebas)

Variabel dependen adalah variabel yang dapat dipengaruhi oleh variabel independen. Dalam skripsi ini variabel dependen adalah peningkatan kemampulabaan $\left(\mathrm{Y}_{1}\right)$ dan pertumbuhan perusahaan $\left(\mathrm{Y}_{2}\right)$.

Tabel 3.3

Operasionalisasi Variabel

\begin{tabular}{|c|c|c|c|}
\hline Variabel & Fungsi & Indikator & Skala/Ukuran \\
\hline Arus Kas Operasi & $\mathrm{X} 1$ & $\frac{\text { Aruskast }- \text { Aruskast }-1}{\text { Aruskas } \cdots t-1}$ & Rasio \\
\hline Manajemen Aset & $\mathrm{X} 2$ & TATO & Rasio \\
\hline Kemampulabaan & $\mathrm{Y1}$ & Laba Operasi & Rasio \\
\hline $\begin{array}{l}\text { Pertumbuhan } \\
\text { Perusahaan }\end{array}$ & Y2 & $\frac{\text { Penjualant }- \text { Penjualant }-1}{\text { Penjualan } \cdots t-1}$ & Rasio \\
\hline
\end{tabular}

\subsection{Jenis dan Sumber Data}


Data adalah fakta yang menggambarkan lewat angka, simbol, kode dan lainnya. Untuk memperoleh data dan keterangan - keterangan yang diperlukan untuk penelitian ini , maka penulis menggunakan data :

Data Sekunder (Secondary Data)

Data sekunder merupakan data yang didapat tidak langsung dari sumber aslinya atau data primer yang telah diolah lebih lanjut dan disajikan misalnya dalam bentuk catatan atau laporan dan tabel - tabel atau diagram - diagram yang telah tersusun rapi dalam arsip (data dokumenter) yang dipublikasikan atau yang tidakdipublikasikan

Jenis data sekunder yang digunakan oleh penulis dalam melakukan penelitian ini adalah data sekunder. Data sekunder adalah data yang ditrerbitkan atau digunakan oleh orang atau organisasi yang bukan pengelolanya. Data sekunder dari penelitian ini adalah data yang diperoleh dari lembaga Bursa Efek Indonesia dengan membeli data perusahaan di Pojok BEI yang berada di STIE Kesatuan serta penulis melakukan studi kepustakaan.

\subsection{Prosedur Pengumpulan Data}

Dalam melakukan penelitian ini yang berjudul "Pengaruh Arus Kas Operasi dan Manajemen Aset Terhadap Peningkatan Kemampulabaan, Pertumbuhan Perusahaan". Dimana penulis melakukan studi kasus pada PT. Indocement Tunggal Prakarsa dan PT. Semen Gresik, Tbk prosedur yang digunakan dalam pengumpulan data dan informasi sebagai pendukung penyusunan skripsi ini adalah sebagai berikut :

1. Studi Kepustakaan (Library Research)

Studi kepustakaan atau library research adalah salah satu bentuk penelitian dengan tujuan memperoleh data dan informasi yang diperlukan, denganstudi 
literatur yang bersumber pada buku- buku yang berkaitan dengan masalah yang akan diteliti sebagai bahan acuan.

Studi literatur yang dilakukan penulis berasal dari perpustakaan yang terdapat di STIE Kesatuan Bogor. Selain itu penulis juga melakukan studi kepustakaan melaui internet dengan situs www.digilib.usu.ac.id

2. Internet Browsing

Penulis mengumpulkan data - data melalui internet browsing, yaitu merupakan metode pengumpulan data melalui situs - situs perusahaan berupa catatan sejarah perusahaan dan yang berkaitan dengan perusahaan seperti visi misi dn sturktur organisasinya.

Penulis selain menggunakan data dari internet browsing, penulis juga membeli data dari pojok BEI yang berada di STIE Kesatuan karena penulis tidak meninjau langsung ke perusahaan tersebut, sehingga penulis membeli data dari Pojok BEI dan penulis dapat melengkapi pembahasan penelitian ini dan melakukan analisis.

\subsection{Metode Analisis}

Teknik yang digunakan dalam menganalisis pengaruh arus kas operasi dan manajemen aset terhadap peningkatan kemampulabaan dan pertumbuhan perusahaan dengan menggunakan data yang akan diperoleh di dalam laporan keuangan pada perusahaan yang akan diteliti.

\section{Analisis Rasio}

a. Arus Kas Operasi

Arus kas operasi didapat berdasarkan data dari laporan arus kas operasi perusahaan yaitu dengan melihat pada arus kas bersih dari aktivitas 
operasi. Arus kas operasi disusun dengan menggunakan metode langsung (Direct Method).

b. Kemampulabaan

Untuk mengukur peningkatan kemampulabaan penulis menggunakan laba operasi atau operating profit yaitu laba yang diperoleh setelah laba kotor mengalami pengurangan oleh biaya - biaya operasi yang dikeluarkan oleh perusahaan.

\section{Laba Operasi = Laba Kotor $/$ Gross Profit - Beban Usaha}

c. Total Assets Turnover (TATO)

Rasio yang digunakan untuk menganalisis manajemen aset dalam hal ini adalah Total Asets Turnover (TATO), rasio ini akan dapat menjelaskan atau memberi gambaran kepada penganalisa tentang baik buruknya keadaan atau posisi perputaran aktiva perusahaan. Rasio ini juga dapat menggambarkan seberapa efektif manajemen dalam mengelola semua aktiva perusahaan. Semakin cepat perputaran semua aktiva perusahaan maka semakin baik kinerja manajemen dalam mengelola semua aktiva perusahaan. Total Asets Turnover dapat dihitung dengan rumus sebagai berikut :

Keterangan :

TATO : Total Asets Turn Over atau perputaran aset/aktiva

Sales : Penjualan atau penerimaan bersih perusahaan

Total asets : Total dari aktiva perusahaan yang didapat dari formula : 
Current Asets + Fixed Asets - Current Liabilities,

dimana :

Current Asets : Jumlah aset/aktiva lancar

Fixed Asets : Jumlah aset/aktiva tetap

Current Liabilities : Jumlah kewajiban lancar

d. Pertumbuhan Perusahaan

Untuk mengukur pertumbuhan perusahaan penulis meneliti pertumbuhan perusahaan dari segi penjualan. Penulis menggunakan perbandingan antara penjualan tahun sebelumnya dengan tahun yang akan dianalisis. Adapun rumus yang dipakai oleh penulis adalah :

Pertumbuhan Perusahaan $=\frac{\text { Penjualan Bersih }{ }_{t}-\text { PenjualanBersih }_{t-1}}{\text { PenjualanBersih }}$

\section{Uji Asumsi}

a. Koefesien Korelasi

Metode ini digunakan untuk mengetahui tingkat keeratan hubungan antara ketiga variabel, yaitu arus kas operasi, peningkatan kemampulabaan dan pertumbuhan perusahaan dengan menggunakan rumus koefesien korelasi, yaitu :

$$
R=\frac{n\left(\sum x y\right)-\left(\sum x\right)\left(\sum y\right)}{\sqrt{\left(n\left(\sum x^{2}\right)-\left(\sum x\right)^{2}\right)\left(n\left(\sum y^{2}\right)-\left(\sum y\right)^{2}\right)}}
$$

Keterangan :

$\mathrm{R}=$ Koefesien korelasi

$\mathrm{X}=$ Variabe bebas (Independen) $=$ Arus Kas Operasi

$\mathrm{Y}=$ Variabel terikat $($ Dependen $)=$ Kemampulabaan dan Pertumbuhan

Perusahaan

$\mathrm{n}=$ Jumlah sampel 
nilai $r=$ koefesien korelasi dapat dinyatakan sebagai berikut :

$-1 \leq \mathrm{e} \geq 1$ yang digunakan untuk melihat erat atau tidaknya suatu hubungan .

Jika $r=1$, hubungan ketiga variabel sempurna dan positif, bila mendekati 1, maka hubungan ketiganya sangat kuat dan searah.

Jika $r=-1$, hubungan ketiga variabel sempurna dan negatif, bila mendekati 1, maka hubungan ketiganya tidak searah atau terbalik.

Jika $r=0$, hubungan ketiga variabel tersebut lemah sekali dan tidak ada hubungan antara ketiganya.

b. Koefesien Determinasi

Analisis koefesien determinasi adalah bagian dari keragaman total variabel tidak bebas $Y$ yang dapat diterangkan oleh keragaman variabel bebas $\mathrm{X}$. Metode ini digunakan untuk mengetahui variabel $\mathrm{X}$ (arus kas operasi) terhadap variabel $Y_{1}$ dan $Y_{2}$ (peningkatan kemampulabaan dan pertumbuhan perusahaan). Analisis determinasi ini dapat ditunjukkan oleh persamaan sebagai berikut :

$$
R^{2}=\frac{\left[n\left(\sum x y\right)-\left(\sum x\right)\left(\sum y\right)\right]^{2}}{\sqrt{\left[n\left(\sum x^{2}\right)-\left(\sum x\right)^{2}\right)\left[n\left(\sum y^{2}\right)-\left(\sum y\right)^{2}\right]}}
$$

Keterangan :

$\mathrm{R}^{2}=$ Koefesien determinasi

$\mathrm{n}$ = Jumlah sampel

$\mathrm{X}=$ Variabel bebas $($ Independent $)=$ Arus Kas Operasi

$\mathrm{Y}=$ Variabel terikat $($ Dependent $)=$ Kemampulabaan dan Pertumbuhan

Perusahaan

Semakin besar nilai koefesien determinasi menunjukkan semakin baik kemampuan $\mathrm{X}$ menerangkan $\mathrm{Y}_{1}$ dan $\mathrm{Y}_{2}$, besarnya koefesien determinasi adalah kuadrat dari koefesien korelasi. 


\section{Analisis Regresi Linear Berganda}

Metode ini untuk melihat kejelasan seberapa besar pengaruh variabel bebas (arus kas operasi dan TATO) terhadap variabel terikat (OPM dan pertumbuhan perusahaan), maka penulis menggunakan analisis regresi linear berganda. Persamaan umum model tersebut adalah :

$$
\begin{aligned}
& Y=a+b x 1+c x 2 \\
& a=y-b x 1-c x 2
\end{aligned}
$$

Keterangan :

$\mathrm{X}=$ Variabel bebas $($ Independent $) \quad=$ Arus Kas Operasi dan TATO

$\mathrm{Y}=$ Variabel terikat $($ Dependent $) \quad=$ OPM dan Pertumbuhan

Perusahaan
$\mathrm{a}=$ Konstanta
b = Slope garis regresi / beta .
$\mathrm{n}$ = Jumlah sampel 


\section{BAB IV}

\section{HASIL DAN PEMBAHASAN}

\subsection{Arus Kas Operasi, Total Assets Turnover, Operating Profit Margin dan Pertumbuhan Perusahaan.}

Pada bab ini penulis akan mencoba untuk menganalisis arus kas operasi, manajemen aset diukur dengan TATO, kemampulabaan dalam hal ini diukur dengan laba operasi (Operating Profit), dan pertumbuhan perusahaan yaitu pertumbuhan yang dilihat dari segi penjualan (Sales Growth). Dimana data yang diambil untuk diteliti penulis menggunakan data yang berasal dari laporan keuangan dari tahun 2007 sampai dengan tahun 2011 dimana laporan keuangan yang digunakan adalah laporan tahunan. Perusahaan yang diteliti oleh penulis adalah PT. Indocement Tunggal Prakarsa, Tbk, dan PT. Semen Gresik (Persero), Tbk.

\subsubsection{Arus Kas Operasi PT Indocement Tunggal Prakarsa, Tbk}

Arus kas dari kegiatan operasi merupakan aktivitas penghasil utama pendapatan perusahaan, dimana aktivitas tersebut pada umumnya berasal dari transaksi dan peristiwa lain yang mempengaruhi pendapatan laba atau rugi bersih. Arus kas dari kegiatan operasi merupakan transaksi - transaksi pembelian atau produksi barang - barang dan jasa serta penjualan dan distribusi barang dan jasa tersebut kepada pelanggan.

Berikut ini merupakan arus kas operasi dan penjualan pada perusahaan PT Indocement Tunggal Prakarsa, Tbk pada tahun 2007 2011: 
Tabel 4.1

Arus Kas Operasi dan Penjualan PT Indocement Tunggal Prakarsa, Tbk

\begin{tabular}{|l|c|c|}
\hline Tahun & $\begin{array}{l}\text { Arus kas operasi (dalam } \\
\text { ribuan) }\end{array}$ & Delta Arus Kas Operasi \\
\hline 2007 & 1.403 .488 .344 .089 & \\
\hline 2008 & 1.619 .202 .132 .220 & 0,15 \\
\hline 2009 & 3.184 .421 .623 .015 & 0,97 \\
\hline 2010 & 3.390 .048 .312 .105 & 0,06 \\
\hline 2011 & 3.883 .771 .534 .076 & 0,15 \\
\hline
\end{tabular}

Sumber :data diolah

Dari tabel penjualan dan arus kas operasi diatas dapat diuraikan sebagai berikut :

Pertumbuhan arus kas operasi PT Indocement Tunggal Prakarsa, Tbk tahun 2008,Tbk sebesar 0,15 dengan arus kas operasi PT Indocement Tunggal Prakarsa, Tbk pada tahun 2007 sebesar Rp. 1.403.488.344.089 dan pada tahun 2008 sebesar Rp 1.619.202.132.220. Artinya arus kas operasi perusahaan cukup baik.

Arus kas operasi PT Indocement Tunggal Prakarsa, Tbk pada tahun 2009 mengalami peningkatan dari tahun 2007 dan 2008, yaitu menjadi Rp. 4.246.497.651 yang berarti cukup baik bagi perusahaan karena sesuai dengan peningkatan penjualan.

Arus kas operasi PT Indocement Tunggal Prakarsa, Tbk pada tahun 2009 mengalami peningkatan kembali dari tahun 2007 dan 2008, yaitu menjadi Rp. 3.184.421.623.015. Hal tersebut baik bagi perusahaan karena arus kas operasi perusahaan di kelola dengan efisien. 
Peningkatan arus kas operasi PT Indocement Tunggal Prakarsa, Tbk berdampak positif terhadap penjualan. Hal ini dibuktikan bahwa pada tahun 2010 dan 2011 penjualan mengalami peningkatan sebesar Rp. 11.137.805.243.058 dan Rp. 13.887.892.432.102 dari tahun-tahun sebelumnya. Meskipun pada tahun 2010 arus kas operasi mengalami penurunan yang cukup drastic yaitu menjadi Rp 3.378.416.266.

\section{Arus Kas Operasi}

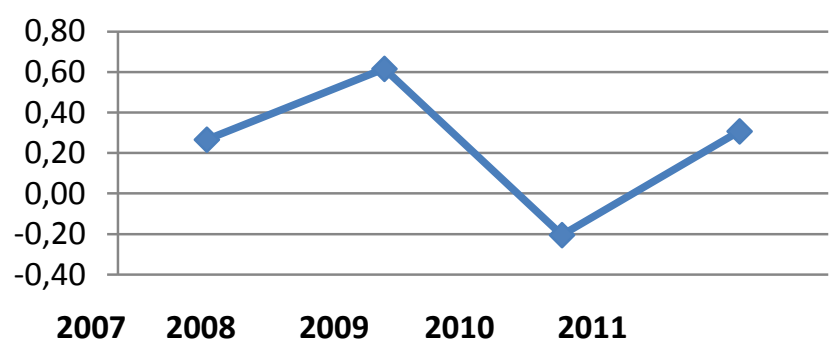

Sumber : Data diolah

Grafik 4.1

Arus Kas Operasi PT Indocement Tunggal Prakarsa, Tbk

Berdasarkan grafik diatas, dapat diketahui bahwa PT Indocement Tunggal Prakarsa, Tbk menghasilkan arus kas operasi tertinggi pada tahun 2009 sebesar 0,62 . Hal ini disebabkan oleh terjadinya peningkatan yang cukup signifikan pada penjualan sebesar $20,08 \%$. Sedangkan arus kas operasi terendah ada pada tahun 2010 yaitu sebesar $-0,20$ Hal ini disebabkan peningkatan penjualan sebesar $12,16 \%$ diikuti dengan peningkatan biaya. Pada tahun ini peningkatan penjualan tidak sebanding dengan peningkatan arus kas operasi sehingga mengakibatkan perputaran arus kas menurun. 
Berdasarkan uraian diatas, dapat diketahui bahwa PT Indocement Tunggal Prakarsa, Tbk pada tahun 2007-2011 dapat mengelola arus kas operasinya dengan baik sehingga dapat menggunakan arus kas dengan efisien dan dapat meningkatkan penjualan.

\subsubsection{Total Assets Turnover PT Indocement Tunggal Prakarsa, Tbk}

Total assets turnover merupakan alat ukur efisiensi dimana perusahaan menggunakan total aktivanya untuk menghasilkan penjualan. Berdasarkan data perusahaan PT Indocement Tunggal Prakarsa, Tbk yang akan menambah pabrik baru maka penulis akan menjabarkan total aktiva yang beroperasi dengan maksimal dan total aktiva yang belum beroperasi dengan maksimal.

Tabel 4.2

Total Assets dan Penjualan PT Indocement Tunggal Prakarsa, Tbk

\begin{tabular}{|l|c|c|c|}
\hline Tahun & Total Assets (dalam ribuan rupiah) & Penjualan (dalam jutaan rupiah) & TATO \\
\hline 2007 & 10.016 .027 .529 .358 & 7.323 .643 .805 .514 & 0,7312 \\
\hline 2008 & 11.286 .706 .863 .779 & 9.780 .498 .326 .080 & 0,8666 \\
\hline 2009 & 13.276 .270 .232 .548 & 10.576 .456 .344 .583 & 0,7966 \\
\hline 2010 & 15.346 .146 .325 .413 & 11.137 .805 .243 .058 & 0,7258 \\
\hline 2011 & 18.151 .331 .254 .708 & 13.887 .892 .432 .102 & 0,7651 \\
\hline
\end{tabular}

Sumber : data diolah

Untuk menghitung total assets turnover pada PT Indocement

Tunggal Prakarsa, Tbk dapat menggunakan rumus sebagai berikut:

$$
\text { TATO }=\frac{\text { Revenue }(\text { sales })}{\text { Total Aset }}
$$

Dari tabel penjualan dan aktiva tetap dihitung dengan menggunakan rumus diatas dapat diuraikan sebagai berikut : 
Apabila dihitung dengan membandingkan dari tahun ke tahun dapat di uraikan bahwa pada tahun 2007 PT Indocement Tunggal Prakarsa, Tbk mempunyai penjualan sebesar $\mathrm{Rp} 7.323 .643 .805 .514$ dan total aset $\mathrm{Rp}$. 10.016.027.529.358, pada tahun 2007 PT Indocement Tunggal Prakarsa, Tbk mempunyai total assets turnover sebanyak 0,7312. Ini berarti PT Indocement Tunggal Prakarsa, Tbk mempunyai perputaran total aktivanya sebanyak 73,12 kali.

Total asset turnover PT Indocement Tunggal Prakarsa, Tbk mengalami peningkatan perputaran dari tahun 2007 artinya aktiva tetap telah berputar sebanyak 86,66 kali atau 0,51 kali lebih besar dibandingkan dengan perputaran tahun 2007. Hal ini disebabkan karena adanya penambahan persediaan dan adanya upaya mempercepat penagihan piutang membuat kas dan setara kas meningkat sekitar 1 milyar. Ini dibuktikan bahwa pada tahun ini total aset mengalami peningkatan 1.270.679ribu dari tahun 2007.

Tahun 2009 total assets turnover PT Indocement Tunggal Prakarsa, Tbk mengalami -0,07(86,66-79,66) dari tahun 2008 ke tahun 2009, artinya perputaran total aset pada tahun 2009 mengalami perputaran 79,66 kali atau 0,09 kali lebih lambat dibanding dari tahun 2008. Hal ini disebabkan karenanya pada tahun ini perusahaan melakukan ekspansi usahanya dengan membangun pabrik baru dan menambah total aktivanya. Dapat dilihat total aset tahun 2009 mengalami peningkatan $\mathrm{Rp} 1.989 .564$ ribu dari tahun sebelumnya. Penambahan total aset ini berdambak positif terhadap penjualan, penjualan pada tahun 2009 mengalami peningkatan sebesar Rp 795.958 ribu.

Pada tahun 2010 TATO PT Indocement Tunggal Prakarsa, Tbk mengalami $-0,0708(79,66-72,58)$ dari tahun 2009 ke tahun 2010, artinya 
perputaran aktiva tetap pada tahun 2010 mengalami perputaran 72,58 kali atau 1,57 kali lebih lambat dibandingkan dari tahun 2009. Hal ini disebabkan karena perusahaan telah menerima sebagian pembayaran dari PT Asuransi Jasindo atas klaim sehubungan dengan kerusakan pada sebagian bagunan dan mesin pabrik karena gempa September tahun 2009 yang lalu. Penerimaan klaim ini belum dioperasionalkan sehingga mengakibatkan penjualan menurun.

Pada tahun 2011 TATO PT Indocement Tunggal Prakarsa, Tbk mengalami $-3,93(72,58-76,51)$ dari tahun 2010 ke tahun 2011, artinya perputaran total aset pada tahun 2011 mengalami perputaran 76,51 kali atau 3,93 kali lebih lambat dibandingkan tahun 2010. Hal ini disebabkan karena perusahaan menambah total aset sebesar Rp18.151.331.254.708 akan tetapi tidak diimbangi dengan penjualan yang sebanding dengan penambahan total aset. Penjualan pada tahun 2011 hanya mengalami peningkatan sebesar $\operatorname{Rp} 2.805 .185$ ribu, ini yang mengakibatkan perputaran total aset menurun.

Dari tabel 4.2 selanjutnya dapat dibuat grafik seperti grafik 4.1

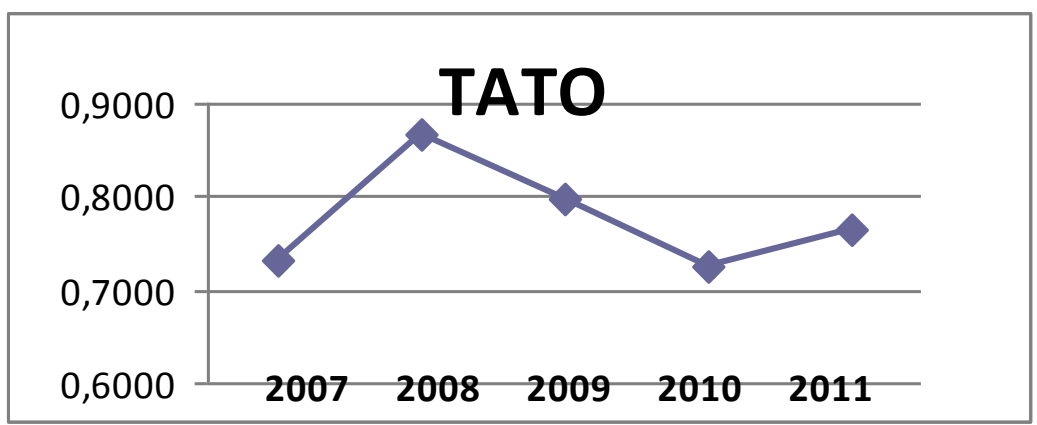

Sumber; diolah

Grafik 4.2

Total Assets turnover PT Indocement Tunggal Prakarsa, Tbk 
Bedasakan gafik diatas dapat diketahui bahwa PT Indocement Tunggal Prakarsa, Tbk mempunyai total assets turnover tertinggi pada tahun 2008 yaitu mencapai 86,66 kali. Pada tahun ini perusahaan menambah total asetnya sebesar $8,4 \%$ akan tetapi perusahaan mampu meningkatkan penjualan sebesar $27,2 \%$. Ini berarti bahwa perusahaan mampu mengelola aktiva tetapnya dengan efisien. Akan tetapi pada tahun 2009-2010 PT Indocement Tunggal Prakarsa, Tbk mengalami penurunan yang cukup tajam. Pada tahun 2009 TATO sebesar 79,66 kali perputaran atau turun 0,07 kali dibanding tahun 2008, TATO pada tahun 2010 sebesar 72,58 kali yaitu mengalami penurunan 0,07 kali pada sebelumnya. Dan pada tahun 2011 TATO PT Indocement Tunggal Prakarsa, Tbk sebesar 76,51 atau turun 3,93 kali perputaran dari tahun 2010. Penurunan pada tahun 2009-2011 disebabkan karena terjadinya bencana alam yaitu gempa di Sumatra yang menyebabkan rusaknya mesin dan bangunan anak perusahaan PT Indocement Tunggal Prakarsa, Tbk.

Berdasarkan uraian diatas, dapat diketahui bahwa PT Indocement Tunggal Prakarsa, Tbk pada periode 2007-2011 memiliki penurunan perputaran total aset. Manajemen perusahaan tidak dapat mengelola total asset dengan efektif sehingga total assets turnover PT Indocement Tunggal Prakarsa, Tbk menurun.

\subsubsection{Operating Profit Margin PT Indocement Tunggal Prakarsa,Tbk}

Kemampulabaan merupakan kemampuan perusahaan dalam menghasilkan laba dari semua sumber daya yang dimiliki oleh 
perusahaan. Kemampulabaan menjadi hampir tujuan semua perusahaan, karena dengan menciptakan kemampulabaan yang baik maka perusahaan dapat tumbuh dan bertahan dari kondisi ekonomi, dan kemampulabaan juga tolok ukur bagi investor untuk mengetahui dividen yang akan dibagikan dan menilai kinerja manajemen perusahaan.

Indikator kemampulabaan yang penulis gunakan adalah net profit margin. Dimana operating profit margin yaitu laba operasi dibagi dengan penjualan. Penelitian dilakukan pada PT Indocement Tunggal Prakarsa, Tbk. Hasil perhitungan dari rasio peningkatan kemampulabaan dalam hal ini dilihat dari operating profit margin pada PT Indocement Tunggal Prakarsa, Tbk dari tahun 2007 sampai dengan tahun 2011 dimana data yang diteliti adalah laporan keuangan tahunan.

Berikut ini adalah penjualan dan laba bersih yag dihasilkan PT Indocement Tunggal Prakarsa, Tbk tahun 2007-2011.

Tabel 4.3

Penjualan dan laba bersih PT Indocement Tunggal Prakarsa, Tbk

\begin{tabular}{|l|c|c|}
\hline Tahun & $\begin{array}{l}\text { Penjualan } \\
\text { (dalam ribuaan rupiah) }\end{array}$ & $\begin{array}{l}\text { Laba Operasi } \\
\text { (dalam ribuan rupiah) }\end{array}$ \\
\hline 2007 & 7.323 .643 .805 .514 & 1.584 .813 .663 .683 \\
\hline 2008 & 9.780 .498 .326 .080 & 2.459 .868 .589 .326 \\
\hline 2009 & 10.576 .456 .344 .583 & 3.693 .305 .458 .982 \\
\hline 2010 & 11.137 .805 .243 .058 & 4.061 .213 .271 .098 \\
\hline 2011 & 13.887 .892 .432 .102 & 4.418 .023 .610 .043 \\
\hline
\end{tabular}

Sumber: data diolah

Untuk menghitung operating profit margin dapat menggunakan rumus sebagai berikut : 


$$
\text { Margin Laba Operasi }=\frac{\text { Laba Operasi }}{\text { Penjualan bersih }}
$$

Dari tabel penjualan dan laba bersih dihitung dengan menggunakan rumus diatas dapat diuraikan sebagai berikut :

Tahun 2007, PT Indocement Tunggal Prakarsa, Tbk laba operasi sebesar $\mathrm{Rp}$ 1.584.813.663.683 dan penjualan yang dimilikinya sebesar $\mathrm{Rp}$ 7.323.643.805.514, ini berarti operating profit margin PT Indocement Tunggal Prakarsa, Tbk tahun 2007 sebesar 0,27. Artinya adalah PT Indocement Tunggal Prakarsa, Tbk pada tahun 2007 mendayagunakan $27 \%$ dari penjualannya untuk meraup keuntungan yang dihasilkannya.

Tahun 2008 mengalami peningkatan 0,01 atau $1 \%$ pada operating profit margin, yaitu $2 \%$ yang didapat dari pembagian laba operasi PT Indocement Tunggal Prakarsa, Tbk tahun 2008 sebesar Rp 2.459.868.589.326 dengan penjualan PT Indocement Tunggal Prakarsa, Tbk tahun 2008 sebesar $\mathrm{Rp} \quad 9.780 .498 .326 .080$ ribu. Peningkatan yang terjadi pada operating profit margin tahun 2008, disebabkan karena terjadinya peningkatan laba operasi.

Operating profit margin PT Indocement Tunggal Prakarsa, Tbk tahun 2009 mengalami peningkatan 15,7 \% yaitu $26 \%$ yang dari pembagi laba operasi sebesar $\mathrm{Rp} 3.693 .305 .458 .982$ dengan penjualan $\mathrm{Rp}$ 10.576.456.344.583 ribu. Peningkatan ini disebabkan adanya peningkatan yang terjadi pada laba operasi dan penjualan.

Operating profit margin PT Indocement Tunggal Prakarsa, Tbk tahun 2010 yaitu sebesar $12 \%$ yang didapat dari pembagian laba operasi Rp 2.327.389.059 dengan penjualan Rp 11.137.805.243.058. Pada tahun 
2009 laba operasi dan penjualan sama-sama mengalami peningkatan akan tetapi pada tahun 2010 terjadinya penurunan laba operasi dan peningkatan penjualan.

Laba operasi tahun 2010 mengalami peningkatan yaitu 4\% dari tahun sebelumnya Rp 3.693.305.458.982 menjadi Rp 4.061.213.271.098. Dan penjualan pada tahun ini mengalami peningkatan sebesar 1,05\% atau sebesar Rp 11.137.805.243.058 dari tahun sebelumnya.

Laba operasi yang dihasilkan PT Indocement Tunggal Prakarsa, Tbk pada tahun 2011 sebesar $R p$ 4.418.023.610.043, penjualan $R p$ 13.887.892.432.102 sehingga operating profit margin yang dimiliki PT Indocement Tunggal Prakarsa, Tbk sebesar $10 \%$. Terjadi penurunan $2 \%$ dari tahun sebelumnya yaitu $12 \%$. Penurunan operating profit margin disebabkan adanya peningkatan laba operasi 10,2\% atau sebesar Rp 4.418.023.610.043 dari tahun sebelumnya. Penjualan juga mengalami peningkatan 12,5\% atau sebesar $R p$ 13.887.892.432.102 dari $R p$ 11.137.805.243.058 pada tahun 2010 menjadi Rp. 13.887.892.432.102 pada tahun 2011.

Dari hasil perhitungan di atas dapat ditampilkan dalam tabel sebagai berikut: 
Tabel 4.4

Net Profit Margin PT Indocement Tunggal Prakarsa, Tbk

\begin{tabular}{|l|r|r|l|}
\hline Tahun & \multicolumn{1}{l|l}{$\begin{array}{l}\text { Penjualan } \\
\text { (dalam ribuaan rupiah) }\end{array}$} & $\begin{array}{l}\text { Laba Bersih } \\
\text { (dalam ribuan rupiah) }\end{array}$ & OPM \\
\hline 2007 & 7.323 .643 .805 .514 & 1.983 .688 .444 .500 & 0,17 \\
\hline 2008 & 9.780 .498 .326 .080 & 1.745 .500 .936 .215 & 0,16 \\
\hline 2009 & 10.576 .456 .344 .583 & 2.746 .654 .071 .082 & 0,17 \\
\hline 2010 & 11.137 .805 .243 .058 & 1.322 .468 .128 .931 & 0,16 \\
\hline 2011 & 13.887 .892 .432 .102 & 1.360 .151 .653 .872 & 0,16 \\
\hline
\end{tabular}

Sumber: data diolah

Dari tabel 4.4 selanjutnya dapat dibuat grafik seperti grafik 4.3

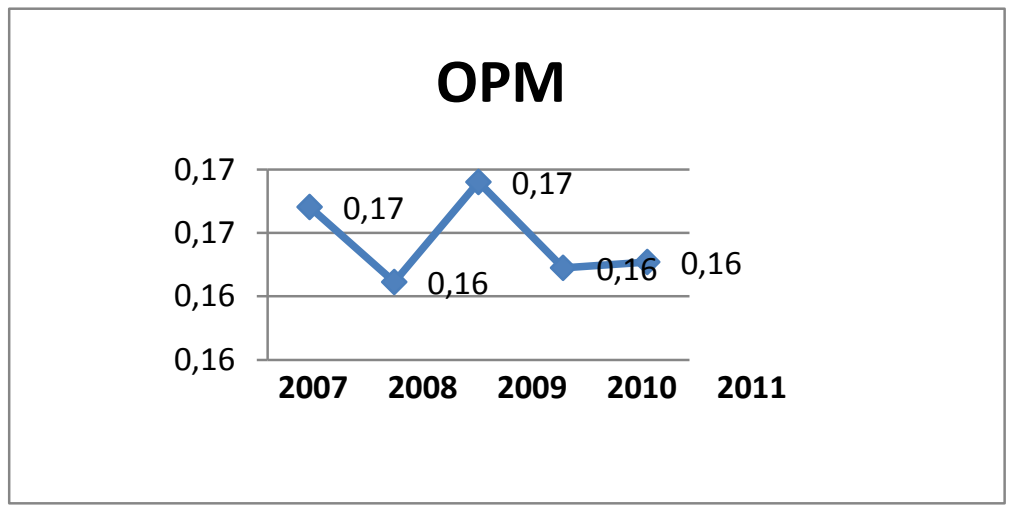

Sumber: data diolah

Grafik 4.3

Pergerakan Net profit margin PT Indocement Tunggal Prakarsa, Tbk

Berdasarkan grafik diatas, dapat diketahui bahwa PT Indocement Tunggal Prakarsa, Tbk menghasilkan operating profit margin tertinggi pada tahun 2007 dan 2009. Tahun 2009 di sebabkan oleh terjadinya peningkatan pada laba operasi sebesar $15,73 \%$ dan penjualan sebesar 
10,8\%. Sedangkan operating profit margin terendah yang dimiliki olen PT Indocement Tunggal Prakarsa, Tbk berada pada tahun 2011 yaitu sebesar 10\%. Berdasarkan uraian diatas, dapat disimpulkan bahwa PT Indocement Tunggal Prakarsa, Tbk mampu meningkatkan penjualan untuk menghasilkan laba perusahaan.

\subsubsection{Pertumbuhan Perusahaan PT Indocement Tunggal Prakarsa,} Tbk

\begin{tabular}{|l|l|l|}
\hline Tahun & Penjualan & $\begin{array}{l}\text { Pertumbuhan } \\
\text { Perusahaan }\end{array}$ \\
\hline 2007 & 7.323 .643 .805 .514 & - \\
\hline 2008 & 9.780 .498 .326 .080 & 0,34 \\
\hline 2009 & 10.576 .456 .344 .583 & 0,08 \\
\hline 2010 & 11.137 .805 .243 .058 & 0,05 \\
\hline 2011 & 13.887 .892 .432 .102 & 0,25 \\
\hline
\end{tabular}

Sumber: Data diolah

Tabel 4.5

Tabel Pertumbuhan Perusahaan tahun 2007-2011

Dari table diatas, yakni dari penjualan dapat dilihat bahwa pertumbuhan perusahaan PT Indocement Tunggal Prakarsa, Tbk mengalami penurunan di tahun kedua yaitu dari 0,34 hingga sebesar 0,08. Pada tahun 2010 mengalami penurunan pula dengan angka sebesar 0,05 dari 0,08 dan hal tersebut disebabkan dengan rendahnya kenaikan penjualan dari tahun sebelumnya. Pada tahun 2011, pertumbuhan perusahaan mengalami 
peningkatan sebesar 0,25 dikarenakan penjualan pada tahun 2011 mengalami peningkatan lebih tinggi dari tahun 2010.

Dari hasil perhitungan diatas dapat disimpulkan dalam grafik 4.4 sebagai berikut:

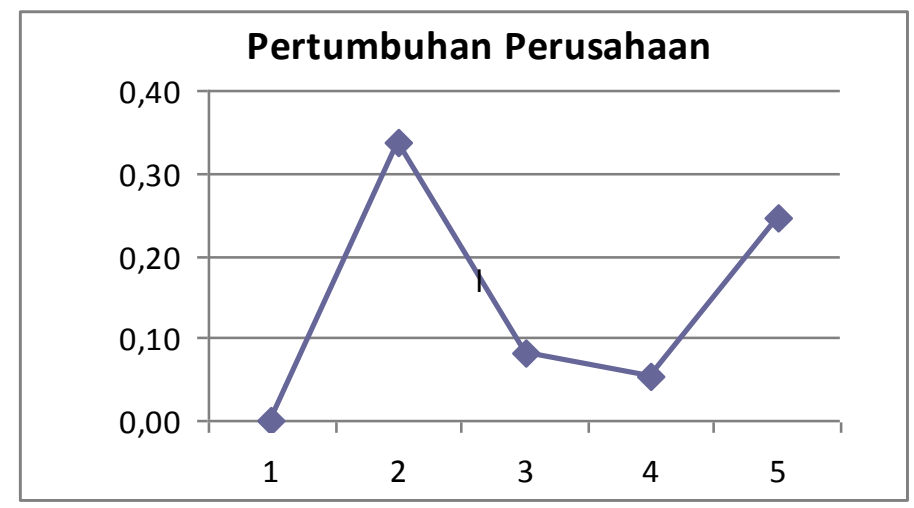

Grafik 4.4

Pergerakan Pertumbuhan Perusahaan PT Indocement Tunggal Prakarsa, Tbk

Berdasarkan grafik diatas, dapat diketahui bahwa PT Indocement Tunggal Prakarsa, Tbk menghasilkan pertumbuhan perusahaan tertinggi pada tahun 2008. Tahun 2009 dan 2010 menurun di sebabkan oleh terjadinya penurunan pada penjualan sebesar 0,08 dan $0,05 \%$. Sedangkan pertumbuhan perusahaan terendah yang dimiliki olen PT Indocement Tunggal Prakarsa, Tbk berada pada tahun 2010 yaitu sebesar 0,05. Berdasarkan uraian diatas, dapat disimpulkan bahwa PT Indocement Tunggal Prakarsa, Tbk mampu meningkatkan penjualan untuk meningkatkan pertumbuhan perusahaan. 


\subsubsection{Arus Kas Operasi PT Semen Gresik (Persero), Tbk}

Arus kas dari kegiatan operasi merupakan aktivitas penghasil utama pendapatan perusahaan, dimana aktivitas tersebut pada umumnya berasal dari transaksi dan peristiwa lain yang mempengaruhi pendapatan laba atau rugi bersih. Arus kas dari kegiatan operasi merupakan transaksi - transaksi pembelian atau produksi barang - barang dan jasa serta penjualan dan distribusi barang dan jasa tersebut kepada pelanggan.

Berikut ini merupakan arus kas operasi dan penjualan pada perusahaan PT Semen Gresik (Persero) Tbk pada tahun 2007 - 2011:

Tabel 4.6

Arus Kas Operasi dan Penjualan PT. Semen Gresik (Persero), Tbk

\begin{tabular}{|l|c|c|}
\hline Tahun & $\begin{array}{l}\text { Arus kas operasi (dalam } \\
\text { ribuan) }\end{array}$ & Delta Arus Kas Operasi \\
\hline 2007 & 2.074 .598 .275 & 0,27 \\
\hline 2008 & 2.628 .307 .576 & 0,62 \\
\hline 2009 & 4.246 .497 .651 & $-0,20$ \\
\hline 2010 & 3.378 .416 .266 & 0,31 \\
\hline 2011 & 4.415 .753 .322 & 0,31 \\
\hline
\end{tabular}

Sumber :data diolah

Dari tabel penjualan dan arus kas operasi diatas dapat diuraikan sebagai berikut :

Pertumbuhan arus kas operasi PT Semen Gresik (Persero) Tbk tahun 2008,Tbk sebesar 0,27 dengan arus kas operasi PT Semen Gresik (Persero) Tbk pada tahun 2007 sebesar Rp. 2.074.598.275 dan pada tahun 2008 sebesar Rp. 2.628.307.576 Artinya arus kas operasi perusahaan cukup baik. 
Arus kas operasi PT Semen Gresik (Persero) Tbk pada tahun 2009 mengalami peningkatan dari tahun 2007 dan 2008, yaitu menjadi Rp. 4.246.497.651 yang berarti cukup baik bagi perusahaan karena sesuai dengan peningkatan penjualan.

Arus kas operasi PT Semen Gresik (Persero) Tbk pada tahun 2009 mengalami peningkatan kembali dari tahun 2007 dan 2008, yaitu menjadi Rp. 3.184.421.623.015. Hal tersebut baik bagi perusahaan karena arus kas operasi perusahaan di kelola dengan efisien.

Peningkatan arus kas operasi PT Semen Gresik (Persero) Tbk berdampak positif terhadap penjualan. Hal ini dibuktikan bahwa pada tahun 2010 dan 2011 penjualan mengalami peningkatan sebesar Rp. 11.137.805.243.058 dan Rp. 13.887.892.432.102 dari tahun-tahun sebelumnya. Meskipun pada tahun 2010 arus kas operasi mengalami penurunan yang cukup drastic yaitu menjadi Rp 3.378.416.266.

\section{Arus Kas Operasi}

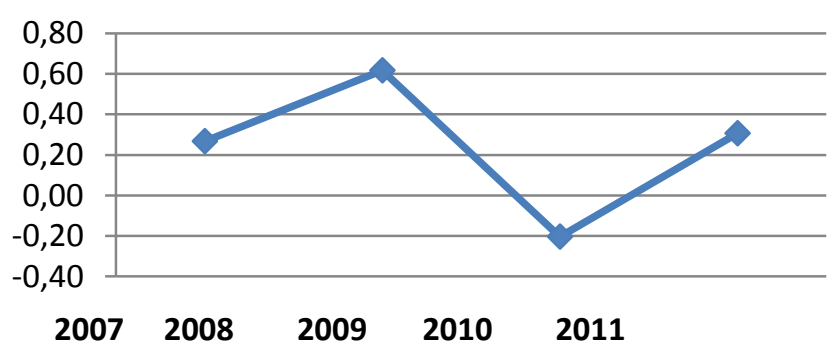

Sumber : Data diolah

Grafik 4.1

Arus Kas Operasi PT Semen Gresik (Persero) Tbk

Berdasarkan grafik diatas, dapat diketahui bahwa PT Semen Gresik (Persero) Tbk menghasilkan arus kas operasi tertinggi pada tahun 2009 
sebesar 0,62 . Hal ini disebabkan oleh terjadinya peningkatan yang cukup signifikan pada penjualan sebesar $20,08 \%$. Sedangkan arus kas operasi terendah ada pada tahun 2010 yaitu sebesar $-0,20$ Hal ini disebabkan peningkatan penjualan sebesar $12,16 \%$ diikuti dengan peningkatan biaya. Pada tahun ini peningkatan penjualan tidak sebanding dengan peningkatan arus kas operasi sehingga mengakibatkan perputaran arus kas menurun.

Berdasarkan uraian diatas, dapat diketahui bahwa PT Indocement Tunggal Prakarsa, Tbk pada tahun 2007-2011 dapat mengelola arus kas operasinya dengan baik sehingga dapat menggunakan arus kas dengan efisien dan dapat meningkatkan penjualanDari tabel penjualan dan arus kas operasi diatas dapat diuraikan sebagai berikut :

\subsubsection{Total Assets Turnover PT Semen Gresik (Persero), Tbk}

Total assets turnover merupakan alat ukur efisiensi dimana perusahaan menggunakan total aktivanya untuk menghasilkan penjualan. Berdasarkan data perusahaan PT Semen Gresik (Persero) Tbk yang akan menambah pabrik baru maka penulis akan menjabarkan total aktiva yang beroperasi dengan maksimal dan total aktiva yang belum beroperasi dengan maksimal. 
Tabel 4.7

Total Assets dan Penjualan PT Semen Gresik (Persero) Tbk

\begin{tabular}{|l|c|c|l|}
\hline Tahun & $\begin{array}{l}\text { Total Assets (dalam ribuan } \\
\text { rupiah) }\end{array}$ & $\begin{array}{l}\text { Penjualan (dalam jutaan } \\
\text { rupiah) }\end{array}$ & TATO \\
\hline 2007 & 10.016 .027 .529 .358 & 7.323 .643 .805 .514 & 0,7312 \\
\hline 2008 & 11.286 .706 .863 .779 & 9.780 .498 .326 .080 & 0,8666 \\
\hline 2009 & 13.276 .270 .232 .548 & 10.576 .456 .344 .583 & 0,7966 \\
\hline 2010 & 15.346 .146 .325 .413 & 11.137 .805 .243 .058 & 0,7258 \\
\hline 2011 & 18.151 .331 .254 .708 & 13.887 .892 .432 .102 & 0,7651 \\
\hline
\end{tabular}

Sumber : data diolah

Untuk menghitung total assets turnover pada PT Semen Gresik(Persero) Tbk dapat menggunakan rumus sebagai berikut:

Total Assets Turnover $=$ Revenue (Sales)

Total Assets

Dari tabel penjualan dan aktiva tetap dihitung dengan menggunakan rumus diatas dapat diuraikan sebagai berikut :Apabila dihitung dengan membandingkan dari tahun ke tahun dapat di uraikan bahwa pada tahun 2007 PT. Semen Gresik (Persero), Tbk mempunyai penjualan sebesar $\mathrm{Rp}$ 7.323.643.805.514 dan total aset $\mathrm{Rp}$. 10.016.027.529.358, pada tahun 2007 PT. Semen Gresik mempunyai total assets turnover sebanyak 0,7312. Ini berarti PT. Semen Gresik (Persero) mempunyai perputaran total aktivanya sebanyak 73,12 kali.

Total asset turnover PT. Semen Gresik (Persero), Tbk mengalami peningkatan perputaran dari tahun 2007 artinya aktiva tetap telah berputar sebanyak 86,66 kali atau 0,51 kali lebih besar dibandingkan dengan 
perputaran tahun 2007. Hal ini disebabkan karena adanya penambahan persediaan dan adanya upaya mempercepat penagihan piutang membuat kas dan setara kas meningkat sekitar 1 milyar. Ini dibuktikan bahwa pada tahun ini total aset mengalami peningkatan 1.270.679ribu dari tahun 2007.

Tahun 2009 total assets turnover PT Semen Gresik (Persero), Tbk mengalami -0,07(86,66-79,66) dari tahun 2008 ke tahun 2009, artinya perputaran total aset pada tahun 2009 mengalami perputaran 79,66 kali atau 0,09 kali lebih lambat dibanding dari tahun 2008. Hal ini disebabkan karenanya pada tahun ini perusahaan melakukan ekspansi usahanya dengan membangun pabrik baru dan menambah total aktivanya. Dapat dilihat total aset tahun 2009 mengalami peningkatan Rp 1.989.564 ribu dari tahun sebelumnya. Penambahan total aset ini berdambak positif terhadap penjualan, penjualan pada tahun 2009 mengalami peningkatan sebesar Rp 795.958 ribu.

Pada tahun 2010 TATO PT Semen Gresik (Persero),Tbk mengalami -0,0708(79,66-72,58) dari tahun 2009 ke tahun 2010, artinya perputaran aktiva tetap pada tahun 2010 mengalami perputaran 72,58 kali atau 1,57 kali lebih lambat dibandingkan dari tahun 2009. Hal ini disebabkan karena perusahaan telah menerima sebagian pembayaran dari PT Asuransi Jasindo atas klaim sehubungan dengan kerusakan pada sebagian bagunan dan mesin pabrik karena gempa September tahun 2009 yang lalu. Penerimaan klaim ini belum dioperasionalkan sehingga mengakibatkan penjualan menurun.

Pada tahun 2011 TATO PT Semen Gresik (Persero),Tbk mengalami $-3,93(72,58-76,51)$ dari tahun 2010 ke tahun 2011, artinya 
perputaran total aset pada tahun 2011 mengalami perputaran 76,51 kali atau 3,93 kali lebih lambat dibandingkan tahun 2010. Hal ini disebabkan karena perusahaan menambah total aset sebesar Rp18.151.331.254.708 akan tetapi tidak diimbangi dengan penjualan yang sebanding dengan penambahan total aset. Penjualan pada tahun 2011 hanya mengalami peningkatan sebesar $\mathrm{Rp}$ 2.805.185ribu, ini yang mengakibatkan perputaran total aset menurun.

Dari tabel 4.2 selanjutnya dapat dibuat grafik seperti grafik 4.1

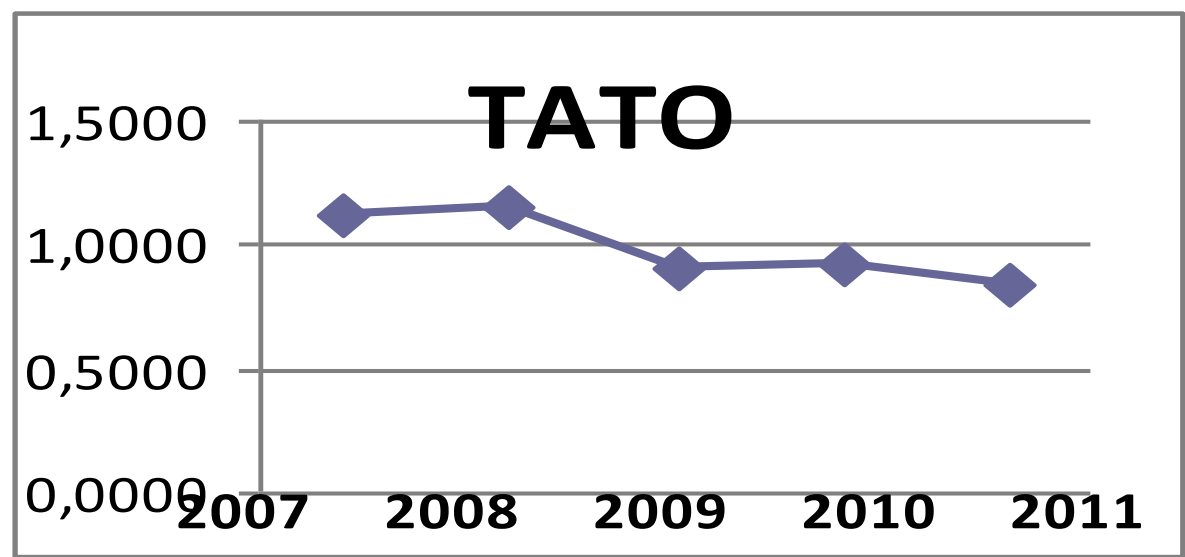

Grafik 4.6

Total Assets turnover PT. Semen Gresik (Persero) Tbk

Bedasakan gafik diatas dapat diketahui bahwa PT. Semen Gresik (Persero), Tbk mempunyai total assets turnover tertinggi pada tahun 2008 yaitu mencapai 86,66 kali. Pada tahun ini perusahaan menambah total asetnya sebesar $8,4 \%$ akan tetapi perusahaan mampu meningkatkan penjualan sebesar $27,2 \%$. Ini berarti bahwa perusahaan mampu mengelola aktiva tetapnya dengan efisien. Akan tetapi pada tahun 20092010 PT.Semen Gresik (Persero), Tbk mengalami penurunan yang cukup tajam. Pada tahun 2009 TATO sebesar 79,66 kali perputaran atau turun 0,07 kali dibanding tahun 2008, TATO pada tahun 2010 sebesar 72,58 kali 
yaitu mengalami penurunan 0,07 kali pada sebelumnya. Dan pada tahun 2011 TATO PT Semen gresik (Persero) Tbk sebesar 76,51 atau turun 3,93 kali perputaran dari tahun 2010. Penurunan pada tahun 2009-2011 disebabkan karena terjadinya bencana alam yaitu gempa di Sumatra yang menyebabkan rusaknya mesin dan bangunan anak perusahaan PT Semen Gresik (Persero), Tbk.

Berdasarkan uraian diatas, dapat diketahui bahwa PT Semen Gresik (Persero),Tbk pada periode 2007-2011 memiliki penurunan perputaran total aset. Manajemen perusahaan tidak dapat mengelola total asset dengan efektif sehingga total assets turnover PT Semen Gresik (Persero) Tbk menurun.

\subsubsection{Operating Profit Margin PT Semen Gresik (Persero),Tbk}

Kemampulabaan merupakan kemampuan perusahaan dalam menghasilkan laba dari semua sumber daya yang dimiliki oleh perusahaan. Kemampulabaan menjadi hampir tujuan semua perusahaan, karena dengan menciptakan kemampulabaan yang baik maka perusahaan dapat tumbuh dan bertahan dari kondisi ekonomi, dan kemampulabaan juga tolok ukur bagi investor untuk mengetahui dividen yang akan dibagikan dan menilai kinerja manajemen perusahaan.

Indikator kemampulabaan yang penulis gunakan adalah operating profit margin. Dimana operating profit margin yaitu laba bersih dibagi dengan penjualan. Penelitian dilakukan pada PT. Semen Gresik (Persero), Tbk. Hasil perhitungan dari rasio peningkatan kemampulabaan dalam hal ini dilihat dari operating profit margin pada PT. Semen Gresik (Persero),Tbk dari tahun 2007 
sampai dengan tahun 2011 dimana data yang diteliti adalah laporan keuangan tahunan.

Berikut ini adalah penjualan dan laba bersih yag dihasilkan PT Semen Gresik (Persero) Tbk tahun 2007-2011.

Tabel 4.8

Penjualan dan laba operasi PT Semen Gresik (Persero)Tbk

\begin{tabular}{|l|l|l|}
\hline Tahun & $\begin{array}{l}\text { Penjualan } \\
\text { (dalam ribuaan rupiah) }\end{array}$ & $\begin{array}{l}\text { Laba Operasi } \\
\text { (dalam ribuan rupiah) }\end{array}$ \\
\hline 2007 & 9.600 .800 .642 & 1.983 .688 .444 .500 \\
\hline 2008 & 12.209 .846 .050 & 1.745 .500 .936 .215 \\
\hline 2009 & 14.387 .849 .799 & 2.746 .654 .071 .082 \\
\hline 2010 & 14.344 .188 .706 & 1.322 .468 .128 .931 \\
\hline 2011 & 16.378 .793 .758 & 1.360 .151 .653 .872 \\
\hline
\end{tabular}

Sumber: data diolah

Untuk menghitung operating profit margin dapat menggunakan rumus sebagai berikut :

$$
\text { Margin Laba Operasi }=\frac{\text { Laba Operasi }}{\text { Penjualan bersih }}
$$

Dari tabel penjualan dan laba bersih dihitung dengan menggunakan rumus diatas dapat diuraikan sebagai berikut :

Tahun 2007, PT. Semen Gresik (Persero), Tbk laba operasi sebesar Rp 1.603.808.237 dan penjualan yang dimilikinya sebesar $R p$ 7.323.643.805.514ribu, ini berarti operating profit margin PT. Semen Gresik (Persero), Tbk tahun 2007 sebesar 0,27. Artinya adalah PT. Semen Gresik (Persero), Tbk pada tahun 2007 mendayagunakan $27 \%$ dari penjualannya untuk meraup keuntungan yang dihasilkannya. 
Tahun 2008 mengalami peningkatan 0,01 atau $1 \%$ pada operating profit margin, yaitu $2 \%$ yang didapat dari pembagian laba operasi PT. Semen Gresik (Persero), Tbk tahun 2008 sebesar Rp 1.967.434.974 dengan penjualan PT. Semen Gresik (Persero), Tbk tahun 2008 sebesar Rp $\quad 9.780 .498 .326 .080$ ribu. Peningkatan yang terjadi pada operating profit margin tahun 2008, disebabkan karena terjadinya peningkatan laba operasi.

Operating profit margin PT. Semen Gresik (Persero), Tbk tahun 2009 mengalami peningkatan $15,7 \%$ yaitu $26 \%$ yang dari pembagi laba bersih sebesar $R p \quad 2.431 .577 .943$ dengan penjualan $R p$ 10.576.456.344.583 ribu. Peningkatan ini disebabkan adanya peningkatan yang terjadi pada laba operasi dan penjualan.

Operating profit margin PT. Semen Gresik (Persero), Tbk tahun 2010 yaitu sebesar $12 \%$ yang didapat dari pembagian laba operasi $\mathrm{Rp}$ 2.327.389.059 dengan penjualan $\mathrm{Rp} \quad 11.137 .805 .243 .058$ ribu. Pada tahun 2009 laba operasi dan penjualan sama-sama mengalami peningkatan akan tetapi pada tahun 2010 terjadinya penurunan laba operasi dan peningkatan penjualan.

Laba operasi tahun 2010 mengalami penurunan yaitu 4\% dari tahun sebelumnya $\mathrm{Rp}$ 2.746.654.071.082 menjadi Rp 1.322.468.128.931. Dan penjualan pada tahun ini mengalami peningkatan sebesar $1,05 \%$ atau sebesar Rp 5.613.489 ribu dari tahun sebelumnya.

Laba operasi yang dihasilkan PT. Semen Gresik (Persero), Tbk pada tahun 2011 sebesar $R p$ 2.664.773.003 , penjualan $R p$ 13.887.892.432.102 ribu sehingga operating profit margin yang dimiliki PT. 
Semen Gresik (Persero), Tbk sebesar $10 \%$. Terjadi penurunan 2\% dari tahun sebelumnya yaitu $12 \%$. Penurunan operating profit margin disebabkan adanya peningkatan laba operasi $10,2 \%$ atau sebesar $\mathrm{Rp}$ 3.768.352.494 ribu dari tahun sebelumnya. Penjualan juga mengalami peningkatan 12,5\% atau sebesar $\mathrm{Rp}$ 2.720.087.189 ribu dari $\mathrm{Rp}$ 11.137.805.243.058 ribu pada tahun 2010 menjadi Rp. 13.887.892.432.102 ribu pada tahun 2011.

Dari hasil perhitungan di atas dapat ditampilkan dalam tabel sebagai berikut:

Tabel 4.4

Net Profit Margin PT. Semen Gresik (Persero), Tbk

\begin{tabular}{|l|l|r|l|}
\hline Tahun & $\begin{array}{l}\text { Penjualan } \\
\text { (dalam ribuaan rupiah) }\end{array}$ & $\begin{array}{l}\text { Laba Bersih } \\
\text { (dalam ribuan rupiah) }\end{array}$ & \multicolumn{1}{l|}{ OPM } \\
\hline 2007 & 9.600 .800 .642 & 1.983 .688 .444 .500 & 0,17 \\
\hline 2008 & 12.209 .846 .050 & 1.745 .500 .936 .215 & 0,16 \\
\hline 2009 & 14.387 .849 .799 & 2.746 .654 .071 .082 & 0,17 \\
\hline 2010 & 14.344 .188 .706 & 1.322 .468 .128 .931 & 0,16 \\
\hline 2011 & 16.378 .793 .758 & 1.360 .151 .653 .872 & 0,16 \\
\hline
\end{tabular}

Sumber: data diolah

Dari tabel 4.4 selanjutnya dapat dibuat grafik seperti grafik 4.3

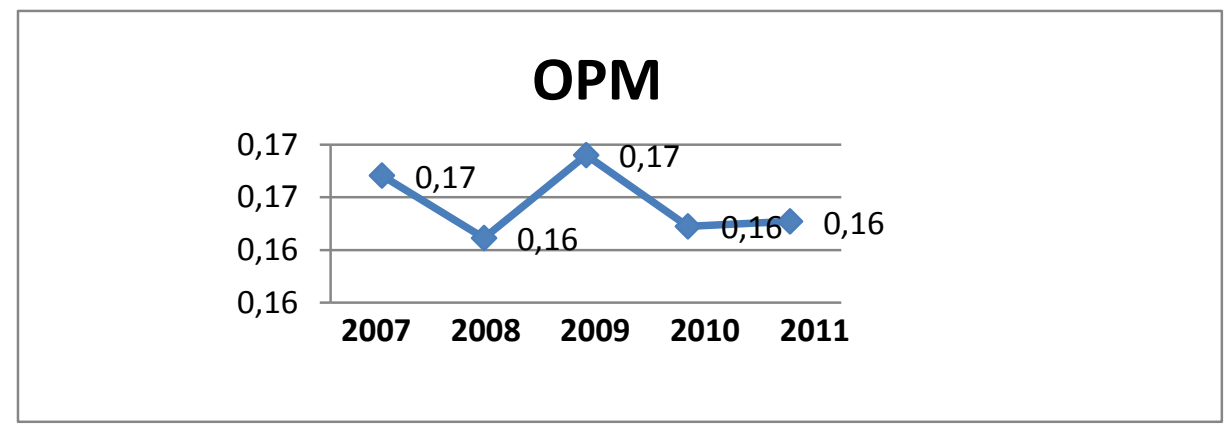

Sumber: data diolah 
Grafik 4.3

Pergerakan Net profit margin PT. Semen Gresik (Persero), Tbk

Berdasarkan grafik diatas, dapat diketahui bahwa PT. Semen Gresik (Persero), Tbk menghasilkan operating profit margin tertinggi pada tahun 2007 dan 2009. Tahun 2009 di sebabkan oleh terjadinya peningkatan pada laba operasi sebesar $15,73 \%$ dan penjualan sebesar 10,8\%. Sedangkan operating profit margin terendah yang dimiliki olen PT. Semen Gresik (Persero), Tbk berada pada tahun 2011 yaitu sebesar 10\%. Berdasarkan uraian diatas, dapat disimpulkan bahwa PT. Semen Gresik (Persero), Tbk mampu meningkatkan penjualan untuk menghasilkan laba perusahaan.

\subsubsection{Pertumbuhan Perusahaan PT Semen Gresik (Persero), Tbk}

\begin{tabular}{|l|r|l|}
\hline Tahun & Penjualan & $\begin{array}{l}\text { Pertumbuhan } \\
\text { Perusahaan }\end{array}$ \\
\hline 2007 & 9.600 .800 .642 & - \\
\hline 2008 & 12.209 .846 .050 & 0,27 \\
\hline 2009 & 14.387 .849 .799 & 0,18 \\
\hline 2010 & 14.344 .188 .706 & 0,00 \\
\hline 2011 & 16.378 .793 .758 & 0,14 \\
\hline
\end{tabular}

Sumber: Data diolah

Tabel 4.10

Tabel Pertumbuhan Perusahaan tahun 2007-2011

Dari table diatas, yakni dari penjualan dapat dilihat bahwa pertumbuhan perusahaan PT Semen Gresik (Persero), Tbk mengalami 
penurunan di tahun 2009 dan 2011 yaitu dari 0,18 hingga sebesar 0,14 yang disebabkan oleh penurunan penjualan yang tidak stabil sehingga memperngaruhi tingkat growth atau pertumbuhan perusahaan. Pada tahun 2010 tidak mengalami perubahan dengan angka sebesar 0,00, hal tersebut disebabkan dengan rendahnya penurunan penjualan yang sama dari taun sebelumnya.

Dari hasil perhitungan diatas dapat disimpulkan dalam grafik 4.4 sebagai berikut:

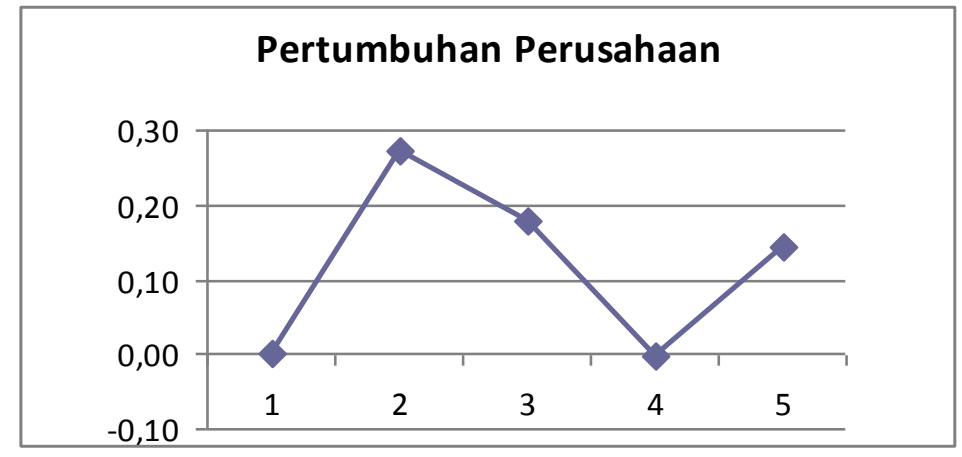

Grafik 4.8

Pergerakan Pertumbuhan Perusahaan PT Semen Gresik (Persero), Tbk Berdasarkan grafik diatas, dapat diketahui bahwa PT Semen Gresik (Persero), Tbk menghasilkan pertumbuhan perusahaan tertinggi pada tahun 2008. Tahun 2009 dan 2010 menurun di sebabkan oleh terjadinya penurunan pada penjualan sebesar 0,08 dan $0,05 \%$. Sedangkan pertumbuhan perusahaan terendah yang dimiliki olen PT Semen Gresik (Persero), Tbk berada pada tahun 2010 yaitu sebesar 0,05. Berdasarkan uraian diatas, dapat disimpulkan bahwa PT Semen Gresik (Persero), Tbk mampu meningkatkan penjualan untuk meningkatkan pertumbuhan perusahaan. 


\subsection{Pengaruh Arus Kas Operasi dan Total Asset Turnover (TATO)}

Terhadap Operating Profit Margin (OPM) dan Pertumbuhan PT. Semen Gresik (Persero), Tbk. .

Berdasarkan penelitian yang dilakukan penulis, berikut ini dikemukakan analisis hipotesis statistic. Dengan menggunakan software versi18,0 data riil dikelompokan dalam tabel dan diolah sesuai dengan variable penelitian. Pengujian terhadap hipotisis statistic dilakukan dengan data dalam pengolahan korelasi linier sederhana dan regresi..

\subsubsection{Pengaruh Arus Kas Operasi dan Total Assets Turnover (TATO) Terhadap Operating Profit Margin (OPM)}

Hasil pengolahan spss versi 18,0 akan disajikan pada hipotesis berikut ini

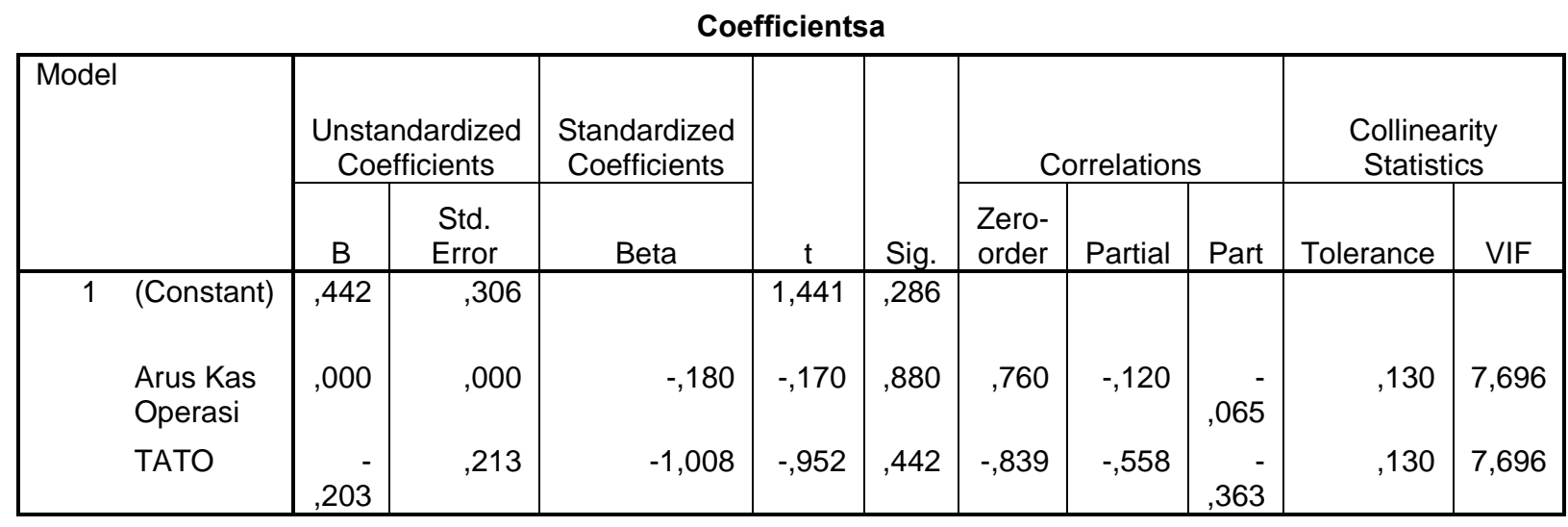

Tabel 4.11

Koefisien Korelasi X1 dan X2 terhadap Y1 PT Semen Gresik (Persero),. Tbk

Konstanta pada persamaan regresi parsial artinya (X1 dan X2) terhadap Y1 (OPM) diperoleh nilai positif sebesar 0,442 artinya persamaan regresi dapat di ambil atau terjadi persamaan regresi dan menjadi penambah terhadap yang lain. 
Koefisien untuk X1 (Arus Kas Operasi), dari persamaan regresi tersebut diperoleh nilai negatif yaitu sebesar $-5,135 \mathrm{E}-12$ atau 0,000000000005135 . Nilai tersebut kurang berpengaruh terhadap $\mathrm{Y} 1$ (OPM) dengan nilai signifikansi 0,88 atau $88 \%$ yakni lebih besar dari 0,05 atau $5 \%$. Hal tersebut dapat dikatakan bahwa setiap kurang dari $1 \%$ perolehan dari X1 kurang mempengaruhi OPM sebesar 0,000000000005135 .

Koefisien untuk X2 (TATO), dari persamaan regresi tersebut diperoleh nilai -0,203. Angka tersebut kurang berpengaruh terhadap Y1 (OPM) karena memiliki nilai signifikansi lebih besar dari $5 \%$ yaitu sebesar $44,2 \%$ atau sebesar 0,442 . Hal tersebut dapat dikatakan bahwa setiap kurang dari $1 \%$ perolehan dari X2 kurang mempengaruhi OPM sebesar 0,442.

Uji Hipotesis 1: Arus kas operasi memiliki pengaruh yang negatif dan tidak signifikan terhadap peningkatan kemampulabaan (OPM). Berdasarkan tabel 4.11 diperoleh nilai $\mathrm{t} \_\mathrm{H}$ sebesar $-0,170$ dengan nilai signifikasi 88,0 atau $88 \%$ yang berada di atas 5\% atau lebih besar dari 0,05. Berdasarkan analisis tersebut maka hipotesis 1 tidak di terima.

Uji Hipotesis 2: Total Assets Turnover (TATO) memiliki pengaruh yang negatif terhadap OPM dengan nilai sebesar -0,203. Berdasarkan tabel 4.11 diperoleh nilai t_H sebesar -0,952 dengan nilai signifikansi sebesar 0,442 atau 44,2\% yang berada di atas 0,05 atau $5 \%$ yang berarti tidak signifikan. Berdasarkan analisis tersebut, maka hipotesis 2 tidak diterima.

\begin{tabular}{|ll|r|r|r|r|r|}
\hline \multicolumn{1}{|c|}{ ANOVA $^{\mathrm{b}}$} \\
\hline 1 & Sum of Squares & df & Mean Square & F & Sig. \\
\hline & Regression &, 002 & 2 &, 001 & 2,436 &, $291^{\mathrm{a}}$ \\
& Residual &, 001 & 2 &, 000 & & \\
& Total &, 003 & 4 & & & \\
\hline
\end{tabular}

a. Predictors: (Constant), TATO, Arus Kas Operasi

b. Dependent Variable: OPM

Tabel 4.12

Pengaruh X1 dan X2 terhadap Y1 PT Semen Gresik (Persero),. Tbk 
Uji Hipotesis 3: Arus kas operasi dan Total Assets Turnover (TATO) tidak berpengaruh signifikan terhadap peningkatan kemampulabaan (OPM) karena memiliki nilai signifikansi lebih dari 5\%. Berdasarkan tabel 4.12 diperoleh $\mathrm{F}$ hitung sebesar 2,436 dengan nilai signifikansi sebesar 0,291 atau 29,1\% yang berarti nilai signifikasi ini berada di atas 0,05 atau 5\%, dengan demikian hipotesis 3 tidak diterima atau ditolak.

\subsubsection{Pengaruh Arus Kas Operasi dan Total Assets Turnover (TATO) terhadap Pertumbuhan Perusahaan (Sales Growth)}

\begin{tabular}{|c|c|c|c|c|c|c|c|c|c|c|}
\hline \multicolumn{11}{|c|}{ Coefficientsa } \\
\hline Model & \multirow{2}{*}{\multicolumn{2}{|c|}{$\begin{array}{c}\text { Unstandardized } \\
\text { Coefficients }\end{array}$}} & \multirow{3}{*}{$\begin{array}{c}\begin{array}{c}\text { Standardized } \\
\text { Coefficients }\end{array} \\
\text { Beta }\end{array}$} & \multirow[b]{3}{*}{$t$} & \multirow[b]{3}{*}{ Sig. } & \multirow{2}{*}{\multicolumn{3}{|c|}{ Correlations }} & \multirow{2}{*}{\multicolumn{2}{|c|}{$\begin{array}{c}\text { Collinearity } \\
\text { Statistics }\end{array}$}} \\
\hline & & & & & & & & & & \\
\hline & $B$ & $\begin{array}{l}\text { Std. } \\
\text { Error }\end{array}$ & & & & $\begin{array}{l}\text { Zero- } \\
\text { order }\end{array}$ & Partial & Part & Tolerance & VIF \\
\hline $1 \quad$ (Constant) & 3,046 & ,528 & & 5,773 & ,029 & & & & & \\
\hline $\begin{array}{l}\text { Arus Kas } \\
\text { Operasi }\end{array}$ &, 000 &, 000 & 2,684 & 6,015 & ,027 & ,245 & ,973 & ,967 & ,130 & 7,696 \\
\hline TATO & 2,146 & ,366 & 2,614 & 5,860 & ,028 & ,111 & ,972 & ,942 & , 130 & 7,696 \\
\hline
\end{tabular}

Tabel 4.13

Koefisien Korelasi X1 dan X2 terhadap Y2 PT Semen Gresik (Persero), Tbk

Konstanta pada persamaan regresi parsial artinya (X1 dan $\mathrm{X} 2)$ terhadap $\mathrm{Y} 1$ (NPM) diperoleh nilai positif sebesar $-3,046$ artinya persamaan regresi dapat di ambil atau terjadi persamaan regresi dan menjadi pengurang terhadap yang lain.

Koefisien untuk X1 (Arus Kas Operasi), dari persamaan regresi tersebut diperoleh nilai negatif yaitu sebesar 3,121E-10 atau 0,0000000003121. Nilai tersebut sangat berpengaruh terhadap Y2 (Sales Growth) dengan nilai signifikansi 0,027 atau 2,7\% yakni berada dibawah 0,05 atau $5 \%$. Hal tersebut dapat dikatakan bahwa setiap kurang dari $1 \%$ perolehan dari $\mathrm{X} 1$ akan mempengaruhi Sales Growth sebesar 0,000000000003121. 
Koefisien untuk X2 (TATO), dari persamaan regresi tersebut diperoleh nilai 2,146. Angka tersebut sangat berpengaruh terhadap Y2 (Sales Growth) karena memiliki nilai signifikansi lebih kecil dari $5 \%$ yaitu sebesar 0,028 atau $2,8 \%$. Hal tersebut dapat dikatakan bahwa setiap kurang dari $1 \%$ perolehan dari X2 akan mempengaruhi pertumbuhan perusahaan (Sale Growth) sebesar 2,146. Uji Hipotesis 1: Arus kas operasi memiliki pengaruh yang positif dan signifikan terhadap pertumbuhan perusahaan (Sales Growth) Berdasarkan tabel 4.13 diperoleh nilai t_H sebesar 6,015 dengan nilai signifikasi 0,027 atau 2,7\% yang berada di bawah 5\% atau lebih kecil dari 0,05. Berdasarkan analisis tersebut maka hipotesis 1 di terima.

Uji Hipotesis 2: Total Assets Turnover (TATO) memiliki pengaruh yang positif terhadap Sales Growth dengan nilai sebesar 2,146. Berdasarkan tabel 4.13 diperoleh nilai t_H sebesar 5,860 dengan nilai signifikansi sebesar 0,028 atau $2,8 \%$ yang berada di bawah 0,05 atau $5 \%$ yang berarti sangat signifikan. Berdasarkan analisis tersebut, maka hipotesis 2 diterima.

\begin{tabular}{|ll|r|r|r|r|r|}
\hline \multicolumn{1}{|c|}{ MNOVA $^{\mathrm{b}}$} & \\
\hline 1 & & Sum of Squares & df & Mean Square & F & Sig. \\
\hline & Regression &, 052 & 2 &, 026 & 18,331 &, $052^{\mathrm{a}}$ \\
& Residual &, 003 & 2 &, 001 & & \\
& Total &, 055 & 4 & & & \\
\hline
\end{tabular}

a. Predictors: (Constant), TATO, Arus Kas Operasi

b. Dependent Variable: Sales Growth

Tabel 4.14

Pengaruh X1 dan X2 terhadap Y2 PT Semen Gresik (Persero),. Tbk

Uji Hipotesis 3: Arus kas operasi dan Total Assets Turnover (TATO) sangat berpengaruh signifikan terhadap pertumbuhan perusahaan (Sales Growth) karena memiliki nilai signifikansi dibawah atau kurang dari 5\%. Berdasarkan tabel 4.14 diperoleh $F$ hitung sebesar 18,331 dengan nilai signifikansi sebesar 0,52 atau $52,1 \%$ yang dapat dikatakan signifikan ini mendekati 0,05 atau $5 \%$, dengan demikian hipotesis 3 diterima. 


\subsection{Pengaruh Arus Kas Operasi dan Total Asset Turnover (TATO) Terhadap Operating Profit Margin (OPM) dan Pertumbuhan PT. Indocement Tunggal Prakarsa, Tbk. .}

Berdasarkan penelitian yang dilakukan penulis, berikut ini dikemukakan analisis hipotesis statistic. Dengan menggunakan software versi18,0 data riil dikelompokan dalam tabel dan diolah sesuai dengan variable penelitian. Pengujian terhadap hipotisis statistic dilakukan dengan data dalam pengolahan korelasi linier sederhana dan regresi..

\subsubsection{Pengaruh Arus Kas Operasi dan Total Assets Turnover (TATO) Terhadap Operating Profit Margin}

Hasil pengolahan spss versi 18,0 akan disajikan pada hipotesis berikut ini

\begin{tabular}{|c|c|c|c|c|c|c|c|c|c|c|}
\hline \multicolumn{11}{|c|}{ Coefficientsa } \\
\hline Model & \multirow{2}{*}{\multicolumn{2}{|c|}{$\begin{array}{l}\text { Unstandardized } \\
\text { Coefficients }\end{array}$}} & \multirow{3}{*}{$\begin{array}{c}\begin{array}{c}\text { Standardized } \\
\text { Coefficients }\end{array} \\
\text { Beta } \\
\end{array}$} & \multirow[b]{3}{*}{$\mathrm{t}$} & \multirow[b]{3}{*}{ Sig. } & \multirow{2}{*}{\multicolumn{3}{|c|}{ Correlations }} & \multirow{2}{*}{\multicolumn{2}{|c|}{$\begin{array}{c}\text { Collinearity } \\
\text { Statistics }\end{array}$}} \\
\hline & & & & & & & & & & \\
\hline & $\mathrm{B}$ & $\begin{array}{l}\text { Std. } \\
\text { Error }\end{array}$ & & & & $\begin{array}{l}\text { Zero- } \\
\text { order }\end{array}$ & Partial & Part & Tolerance & VIF \\
\hline $\begin{array}{ll}1 & \text { (Constant) }\end{array}$ & 429 & ,651 & & ,659 &, 578 & & & & & \\
\hline $\begin{array}{l}\text { Arus Kas } \\
\text { Operasi }\end{array}$ &, 000 & ,000 &,- 650 & $1,124^{-}$ & ,378 &,- 616 &,- 622 & ,620 & ,909 & 1,100 \\
\hline TATO &,- 155 & ,783 &,- 114 &,- 198 & ,862 & ,082 &,- 138 & 109 & ,909 & 1,100 \\
\hline
\end{tabular}

Tabel 4.15

Konstanta pada persamaan regresi parsial artinya (X1 dan X2) terhadap Y1 (OPM) diperoleh nilai positif sebesar 0,429 artinya persamaan regresi dapat di ambil atau terjadi persamaan regresi dan menjadi penambah terhadap yang lain. 
Koefisien untuk X1 (Arus Kas Operasi), dari persamaan regresi tersebut diperoleh nilai negatif yaitu sebesar $-4,553 \mathrm{E}-12$ atau 0,000000000004553 . Nilai tersebut kurang berpengaruh terhadap Y1 (OPM) dengan nilai signifikansi 0,378 atau $37,8 \%$ yakni lebih besar dari 0,05 atau $5 \%$. Hal tersebut dapat dikatakan bahwa setiap kurang dari $1 \%$ perolehan dari X1 kurang mempengaruhi OPM sebesar 0,000000000004553 .

Koefisien untuk X2 (TATO), dari persamaan regresi tersebut diperoleh nilai -0,115. Angka tersebut kurang berpengaruh terhadap Y1 (OPM) karena memiliki nilai signifikansi lebih besar dari $5 \%$ yaitu sebesar $86,2 \%$ atau sebesar $0,862 \mathrm{Hal}$ tersebut dapat dikatakan bahwa setiap kurang dari $1 \%$ perolehan dari X2 kurang mempengaruhi OPM sebesar $-0,115$.

Uji Hipotesis 1: Arus kas operasi memiliki pengaruh yang negatif dan tidak signifikan terhadap peningkatan kemampulabaan (OPM). Berdasarkan tabel 4.15 diperoleh nilai t_H sebesar -1,124 dengan nilai signifikasi 0,378 atau $37,8 \%$ yang berada di atas 5\% atau lebih besar dari 0,05. Berdasarkan analisis tersebut maka hipotesis 1 tidak di terima.

Uji Hipotesis 2: Total Assets Turnover (TATO) memiliki pengaruh yang negatif terhadap OPM dengan nilai sebesar -0,115. Berdasarkan tabel 4.15 diperoleh nilai t_H sebesar -0,198 dengan nilai signifikansi sebesar 0,862 atau $86,2 \%$ yang berada di atas 0,05 atau 5\% yang berarti tidak signifikan. Berdasarkan analisis tersebut, maka hipotesis 2 tidak diterima.

\begin{tabular}{|ll|r|r|r|r|r|}
\hline \multicolumn{1}{|c|}{ MNOVA $^{\mathbf{b}}$} \\
\hline 1 & Sum of Squares & df & Mean Square & F & Sig. \\
\hline & Regression &, 010 & 2 &, 005 &, 643 &, $609^{\mathrm{a}}$ \\
& Residual &, 015 & 2 &, 007 & & \\
& Total &, 024 & 4 & & & \\
\hline
\end{tabular}

a. Predictors: (Constant), TATO, Arus Kas Operasi

b. Dependent Variable: NPM 
Pengaruh X1 dan X2 terhadap Y1 PT Indocement Tunggal Prakarsa, Tbk Uji Hipotesis 3: Arus kas operasi dan Total Assets Turnover (TATO) tidak berpengaruh signifikan terhadap peningkatan kemampulabaan (OPM) karena memiliki nilai signifikansi lebih besar dari 5\%. Berdasarkan tabel 4.16 diperoleh $\mathrm{F}$ hitung sebesar 0,643 dengan nilai signifikansi sebesar 0,609 atau 60,9\% yang berarti nilai signifikasi ini berada di atas 0,05 atau $5 \%$, dengan demikian hipotesis 3 tidak diterima atau ditolak.

\subsubsection{Pengaruh Arus Kas Operasi dan Total Assets Turnover (TATO) terhadap Pertumbuhan Perusahaan (Sales Growth)}

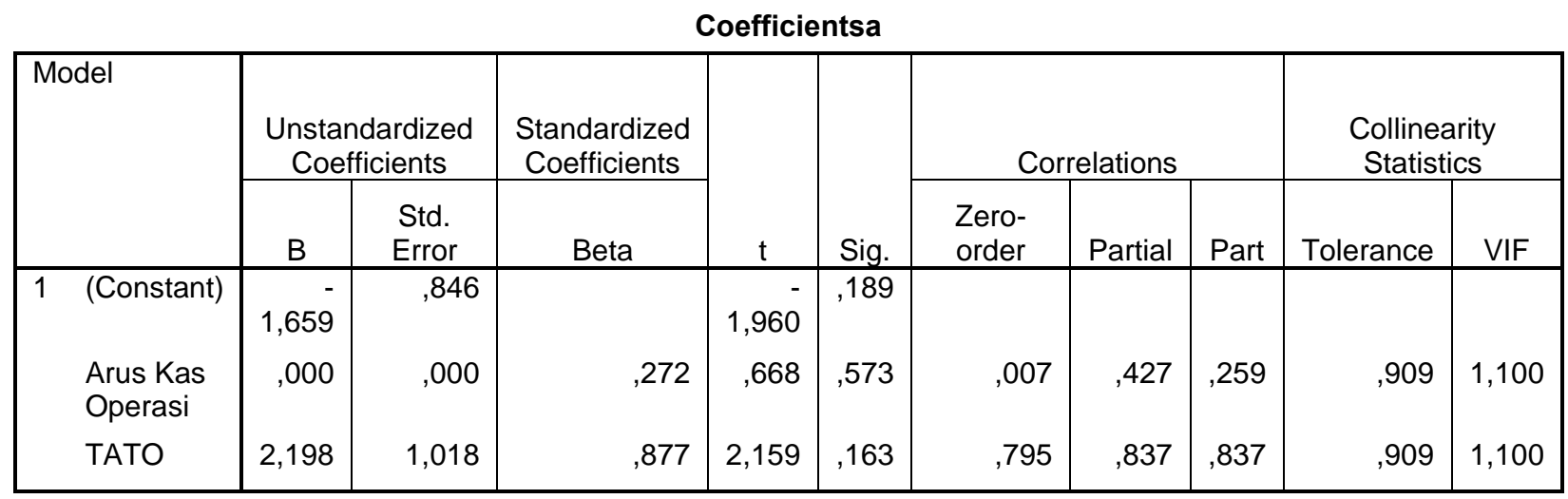

Tabel 4.17

Koefisien Korelasi X1 dan X2 terhadap Y2 PT Indocement Tunggal Prakarsa,Tbk Konstanta pada persamaan regresi parsial artinya (X1 dan $\mathrm{X} 2)$ terhadap $\mathrm{Y} 1$ (NPM) diperoleh nilai positif sebesar -1,659 artinya persamaan regresi dapat di ambil atau terjadi persamaan regresi dan menjadi pengurang terhadap yang lain.

Koefisien untuk X1 (Arus Kas Operasi), dari persamaan regresi tersebut diperoleh nilai negatif yaitu sebesar $3,519 \mathrm{E}-10$ atau 0,0000000003519 . Nilai tersebut sangat berpengaruh terhadap Y2 (Sales Growth) dengan nilai signifikansi 0,573 atau $57,3 \%$ yakni berada di atas 0,05 atau $5 \%$. Hal tersebut 
dapat dikatakan bahwa setiap kurang dari $1 \%$ perolehan dari $\mathrm{X} 1$ tidak akan mempengaruhi Sales Growth.

Koefisien untuk X2 (TATO), dari persamaan regresi tersebut diperoleh nilai 2,198 Angka tersebut tidak berpengaruh terhadap Y2 (Sales Growth) karena memiliki nilai signifikansi lebih besar dari $5 \%$ yaitu sebesar 0,163 atau $16,3 \%$. Hal tersebut dapat dikatakan bahwa setiap kurang dari 1\% perolehan dari X2 tidak akan mempengaruhi pertumbuhan perusahaan (Sale Growth).

Uji Hipotesis 1: Arus kas operasi memiliki pengaruh yang negatif dan signifikan terhadap pertumbuhan perusahaan (Sales Growth) Berdasarkan tabel 4.17 diperoleh nilai t_H sebesar 0,668 dengan nilai signifikasi 0,573 atau 57,3\% yang berada di atas $5 \%$ atau lebih besar dari 0,05 . Berdasarkan analisis tersebut maka hipotesis 1 di tolak.

Uji Hipotesis 2: Total Assets Turnover (TATO) memiliki pengaruh yang positif terhadap Sales Growth dengan nilai sebesar 2,198. Berdasarkan tabel 4.17 diperoleh nilai t_H sebesar 2,159 dengan nilai signifikansi sebesar 0,163 atau $16,3 \%$ yang berada di atas 0,05 atau $5 \%$ yang berarti tidak signifikan. Berdasarkan analisis tersebut, maka hipotesis 2 ditolak.

\begin{tabular}{|ll|r|r|r|r|r|}
\hline \multicolumn{1}{|c|}{ ANOVA $^{\mathrm{b}}$} \\
\hline 1 & Sum of Squares & df & Mean Square & F & Sig. \\
\hline & Regression &, 058 & 2 &, 029 & 2,331 &, $300^{\mathrm{a}}$ \\
& Residual &, 025 & 2 &, 013 & & \\
& Total &, 083 & 4 & & & \\
\hline
\end{tabular}

a. Predictors: (Constant), TATO, Arus Kas Operasi

b. Dependent Variable: Sales Growth

Tabel 4.18

Pengaruh X1 dan X2 terhadap Y2 PT Indocement Tunggal Prakarsa, Tbk Uji Hipotesis 3: Arus kas operasi dan Total Assets Turnover (TATO) tidak berpengaruh signifikan terhadap pertumbuhan perusahaan (Sales Growth) 
karena memiliki nilai signifikansi diatas atau lebih dari 5\%. Berdasarkan tabel 4.18 diperoleh $F$ hitung sebesar 2,331 dengan nilai signifikansi sebesar 0,300 atau $30 \%$ yang dapat dikatakan tidak signifikan karena berada di atas atau lebih besar dari 0,05 atau 5\%, dengan demikian hipotesis 3 ditolak.

\subsection{Analisis Perbandingan Pengelolaan Arus Kas Operasi, Manajemen asset dan Kemampulabaan, Pertumbuhan Perusahaan PT Semen Gresik (Persero) Tbk dan PT Indocement Tunggal Prakarsa Tbk}

Berdasarkan data dan analisis yang telah dilakukan pada PT Semen Gresik (Persero) Tbk dan PT Indocement Tunggal Prakarsa Tbk selama kurun waktu 5 periode yakni dari tahun 2007 sampai dengan tahun 2011, penulis dapat membandingkan antara masing-masing perusahaan mengenai bagaimana manajemen asset dan kemampulabaan perusahaan, serta pengaruh manajemen asset terhadap kemepulabaan. Ini dapat dilihat sebagai berikut :

\section{Arus Kas Operasi}

Arus Kas Operasi PT Semen Gresik (Persero) Tbk dan PT Indocement Tunggal Prakarsa Tbk periode 2007-2011 dibuat dalam bentuk tabel dapat dilihat pada tabel 4.11 berikut ini :

Tabel 4.19 Arus Kas Operasi PT Semen Gresik (Persero) Tbk dan PT Indocement Tunggal Prakarsa Tbk 


\begin{tabular}{|l|c|l|}
\hline Tahun & $\begin{array}{l}\text { PT Semen Gresik } \\
\text { (Persero) Tbk }\end{array}$ & $\begin{array}{l}\text { PT Indocement Tunggal } \\
\text { Prakarsa Tbk }\end{array}$ \\
\hline 2007 & & \\
\hline 2008 & 0,27 & 0,15 \\
\hline 2009 & 0,62 & 0,97 \\
\hline 2010 & $-0,20$ & 0,06 \\
\hline 2011 & 0,31 & 0,15 \\
\hline
\end{tabular}

Sumber: data diolah

Dari tabel 4.18 selanjutnya dapat dibuat grafik 4.9 seperti dibawah ini:

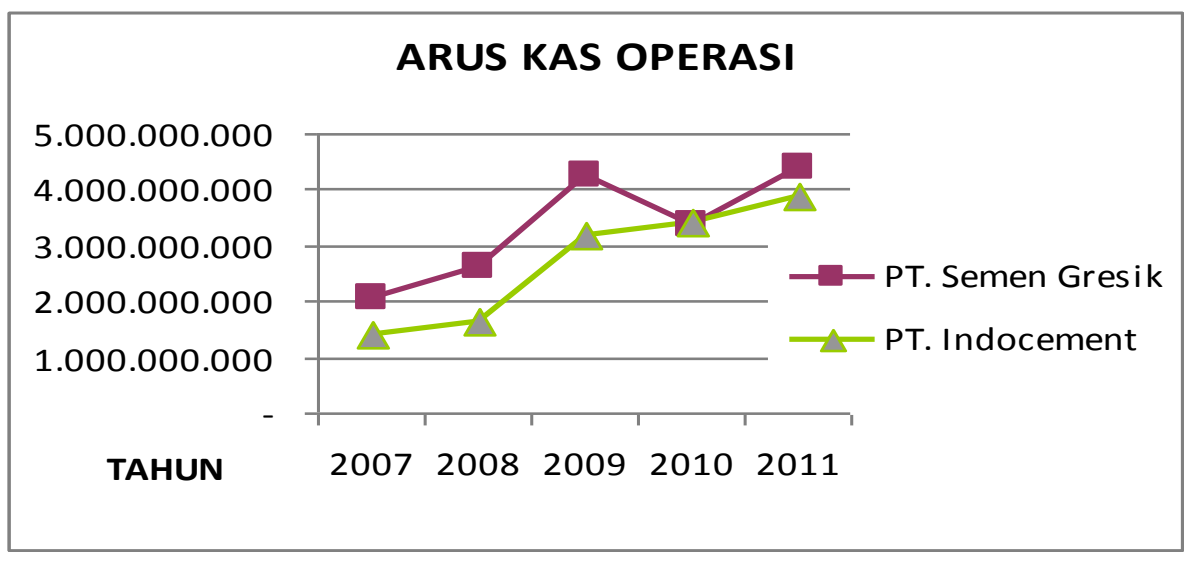

Sumber :data diolah

Gambar 4.9

Pergerakan Arus Kas Operasi PT Semen Gresik (Persero) Tbk dan PT Indocement Tunggal Prakarsa

Dari grafik diatas dapat disimpukan bahwa PT Semen Gresik (Persero)Tbk mengalami penurunan Arus Kas Operasi pada tahun 2007 akan tetapi pada tahun 2008 sampai dengan 2011 mengalami peningkatan yang signifikan. Ini membuktikan bahwa PT Semen Gresik (Persero) Tbk dapat mengelola aktiva lancar dengan efisien. Sama halnya 
dengan PT Indocement Tunggal Prakarsa Tbk memiliki Arus Kas Operasi yang meningkat dari tahun 2007-2011. Peningkatan Arus Kas Operasi PT Indocement Tunggal Prakarsa di sebabkan karena meningkatnya penjualan dan ini membuktikan bahwa PT Indocement Tunggal Prakarsa dapat mengelola aktifa lancar dengan efisien.

\section{Total Assets Turnover}

Untuk membandingkan Total Asset Turnover PT Semen Gresik (Persero) Tbk dan PT Indocement Tunggal Prakarsa Tbk periode 20072011 dibuat tabel 4.12 sebagai berikut :

Tabel 4.12

Total Aset Turnover PT Semen Gresik (Persero) Tbk dan PT Indocemen Tunggal Prakarsa Tbk

\begin{tabular}{|c|c|c|c|}
\hline Tahun & $\begin{array}{l}\text { PT Semen } \\
\text { (Persero) Tbk }\end{array}$ & Gresik & $\begin{array}{l}\text { PT Indocement } \\
\text { Tunggal Prakarsa } \\
\text { Tbk }\end{array}$ \\
\hline 2007 & 1,13 & & 0,73 \\
\hline 2008 & 1,15 & & 0,87 \\
\hline 2009 & 0,90 & & 0,80 \\
\hline 2010 & 0,92 & & 0,73 \\
\hline 2011 & 0,83 & & 0,77 \\
\hline
\end{tabular}

Sumber : Data diolah

Dari tabel 4.20 dibuat grafik 4.10 seperti dibawah ini: 


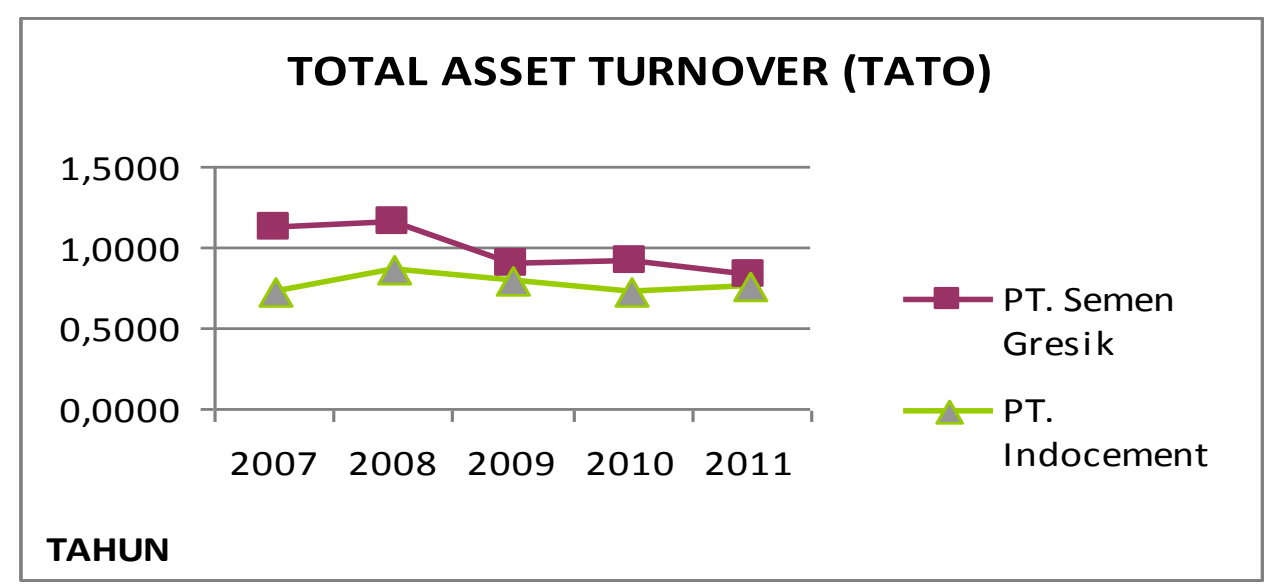

Sumber : data diolah

Grafik 4.10

Total Aset Turnover PT Semen Gresik (Persero) Tbk dan PT Indocement Tunggal Prakarsa Tbk

Dari grafik 4.10 dapat dilihat total asset turnover pada PT Semen Gresik (Persero) Tbk mengalami penurunan pada tahun 2009 dan 2011. Penurunan derastis terjadi pada tahun 2009, hal ini disebabkan pada tahun 2009 karena terjadi gempa di Sumatra yang mengakibatkan rusaknya gedung dan mesin anak perusahaan PT Semen Gresik (Persero) Tbk. Total asset turnover pada PT Indocement Tunggal Prakarsa mengalami penurunan pada tahun 2009-2010. Hal ini membuktikan PT Indocement Tunggal Prakarsa Tbk kurang mampu mengelola aktiva tetap dengan efisien.

\section{Operating Profit Margin}

Untuk membandingkan Net Profit Margin PT.Semen Gresik (Persero) Tbk dan PT Indocement Tunggal Prakarsa Tbk dibuat tabel sebagai berikut : 
Tabel 4.21

Operating Profit Margin PT Semen Gresik (Persero) Tbk dan PT Indocement Tunggal Prakarsa Tbk

\begin{tabular}{|l|c|c|}
\hline Tahun & $\begin{array}{l}\text { PT Semen Gresik } \\
\text { (Persero) Tbk }\end{array}$ & $\begin{array}{l}\text { PT Indocement Tunggal } \\
\text { Prakarsa Tbk }\end{array}$ \\
\hline 2007 & 0,17 & 0,22 \\
\hline 2008 & 0,16 & 0,25 \\
\hline 2009 & 0,17 & 0,35 \\
\hline 2010 & 0,16 & 0,36 \\
\hline 2011 & 0,16 & 0,32 \\
\hline
\end{tabular}

Sumber : data diolah

Dari tabel 4.21 dibuat tabel 4.11 sebagai berikut:

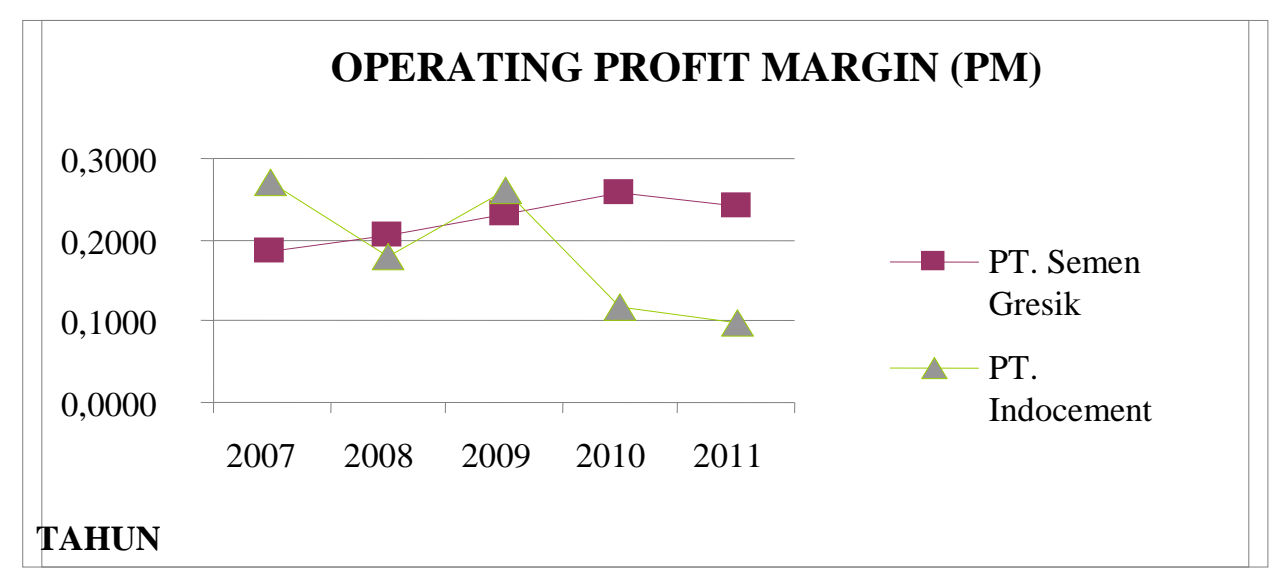

Sumber : data diolah

Grafik 4.11

Operating Profit Margin PT Semen Gresik (Persero) Tbk dan PT Indocement Tunggal Prakarsa 
Dari grafik 4.20 menunjukan Operating profit margin PT Semen Gresik (Persero) Tbk dan PT Indocement Tunggal Prakarsa Tbk mengalami peningkatan pada tahun 2008-2010 dan mengalami penurunan pada tahun 2011. Hal ini membuktikan bahwa PT Semen Gresik (Persero) Tbk dan PT Indocement Tunggal Prakarsa Tbk mampu menciptakan kemampulabaan dengan baik.

\section{Pertumbuhan Perusahaan}

Untuk membandingkan sales growth PT.Semen Gresik (Persero) Tbk dan PT Indocement Tunggal Prakarsa Tbk dibuat tabel sebagai berikut :

Tabel 4.22

Sales growth PT Semen Gresik (Persero) Tbk dan PT Indocement Tunggal Prakarsa Tbk

\begin{tabular}{|l|c|c|}
\hline Tahun & $\begin{array}{l}\text { PT Semen Gresik } \\
\text { (Persero) Tbk }\end{array}$ & $\begin{array}{l}\text { PT Indocement } \\
\text { Tunggal Prakarsa Tbk }\end{array}$ \\
\hline 2007 & 0,00 & 0 \\
\hline 2008 & 0,27 & 0,34 \\
\hline 2009 & 0,18 & 0,08 \\
\hline 2010 & 0,00 & 0,05 \\
\hline 2011 & 0,14 & 0,25 \\
\hline
\end{tabular}

Sumber : data diolah

Dari tabel 4.22 dapat dibuat dengan grafik 4.12 sebagai berikut: 


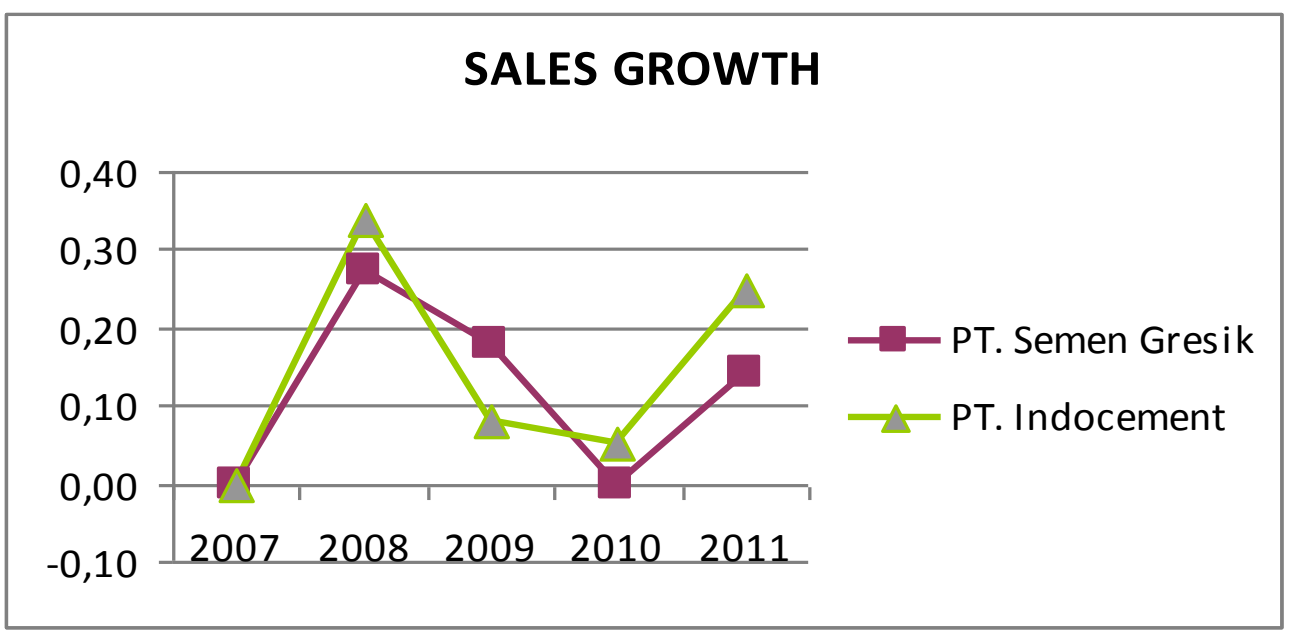

Grafik 4.12

Sales growth PT Semen Gresik (Persero) Tbk dan PT Indocement Tunggal Prakarsa

Dari grafik dapat dilihat sales growth PT Semen Gresik (Persero) Tbk dan PT Indocement Tunggal Prakarsa mengalami peningkatan dari tahun 2008 dan 2011 akan tetapi mengalami penurunan yang cukup drastic pada tahun 2009-2010. Hal ini menunjukkan perusahaan kurang mampu meningkatkan pertumbuhan perusahaan. 


\section{BAB V \\ SIMPULAN DAN SARAN}

\subsection{Simpulan}

Di dalam bab ini penulis akan menarik beberapa kesimpulan berdasarkan pembahasan yang ada pada bab sebelumnya, yaitu berdasarkan hasil perhitungan dan analisis arus kas operasi dan manajemen aset (TATO) terhadap kemampulabaan (NPM) dan pertumbuhan perusahaan (sales growth), dimana hasil perhitungan diperoleh dari laporan keuangan pertriwulan selama 5 tahun, maka dapat disimpulkan sebagai berikut :

1. Arus Kas Operasi

1.1 Nilai tertinggi arus kas dari aktivitas operasi diraih oleh PT Semen Gresik (Persero),. Tbk.

1.2 Arus kas operasi pada PT Semen Gresik (Persero),.. Tbk tidak berpengaruh pada NPM karena lebih dari 5\%, tetapi berpengaruh positif terhadap Sales Growth karena memiliki nilai signifikansi kurang dari $5 \%$.

1.3 Arus kas operasi pada PT Indocement Tunggal Prakarsa,. Tbk tidak berpengaruh terhadap NPM dan Sales Growth karena memiliki nilai signifikansi lebih dari $5 \%$.

2. Manajemen Aset (Total Aset Turnover)

2.1 Nilai tertinggi TATO diraih oleh PT Semen Gresik (Persero),. Tbk.

2.2 TATO pada PT Semen Gresik (Persero),. Tbk tidak berpengaruh terhadap NPM karena nilai signifikansi lebih besar dari $5 \%$ tetapi berpengaruh positif terhadap Sales Growth karena memiliki nilai signifikansi kurang dari $5 \%$. 
2.3 TATO pada PT Indocement Tunggal Prakarsa,. Tbk tidak berpengaruh terhadap NPM dan Sales Growth karena memiliki nilai signifikansi lebih dari 5\%.

3. Kemampulabaan (Net Profit Margin)

3.1 Nilai tertinggi kemampulabaan diraih oleh PT Indocement Tunggal Prakarsa,. Tbk.

3.2 NPM pada PT Semen Gresik (Persero),. Tbk tidak dipengaruhi oleh arus kas operasi dan TATO karena memiliki nilai signifikansi lebih dari $5 \%$.

3.3 NPM pada PT Indocement Tunggal Prakarsa,. Tbk tidak dipengaruhi oleh arus kas operasi dan TATO karena memiliki nilai signifikansi lebih dari 5\%.

4. Pertumbuhan Perusahaan (Sales Growth)

4.1 Nilai tertinggi Sales Growth diraih oleh PT Indocement Tunggal Prakarsa,. Tbk.

4.2 Sales Growth pada PT Semen Gresik (Persero),. Tbk dipengaruhi oleh arus kas operasi dan TATO karena memiliki nilai signifikansi kurang dari $5 \%$.

4.3 Sales Growth pada PT Indocement Tunggal Prakarsa,. Tbk tidak dipengaruhi oleh arus kas operasi dan TATO karena memiliki nilai signifikansi lebih dari 5\%.

\subsection{Saran}

Untuk meningkatkan kas bersih dari aktivitas operasi perusahaan harus melakukan efisiensi pada biaya - biaya dan dapat meningkatkan 
penjualan produk semennya. Perusahaan yang bergerak pada industri semen mempunyai masa depan yang cukup bagus, karena Indonesia sedang dalam tahap pembangunan. Dengan hal tersebut diharapkan perusahaan yang bergerak didalam industri semen dapat memanfatkan hal ini untuk meningkatkan pertumbuhan penjualan mereka dan meningkatkan laba dengan melakukan efisiensi. 


\section{DAFTAR PUSTAKA}

Abdul Halim, Drs, MM, Ak, 2007, Manajemen Keuangan Bisnis. Ghalia Indonesia,

Bogor.

Agnes Sawir. 2005, Analisis Kinerja Keuangan \& Perencanaan Keuangan Perusahaan, Edisi 5, Penerbit PT. Gramedia Pustaka Utama, Jakarta.

Anthony, Robert N., David F. Hawkin, Kennet A. Merchan, 2005. Financial Management Theory and Practice. $10^{\text {th }}$ Edition.

Budi Rahardjo. 2005, Laporan Keuangan Perusahaan, Gadjah Mada University Press, Yogyakarta.

Dewi Astuti. 2004, Manajemen Keuangan Perusahaan, Ghalia Indonesia, Jakarta.

Darmawan Sjahrial.2006. Pengantar Manajemen Keuangan, Penerbit Mitra Wacana Media, Jakarta

Farah Margaretha. 2005, Teori dan Aplikai Manajemen Keuangan : Investasi dan Sumber Dana Jangka Panjang, Penerbit PT. Gramedia Widiasarana Indonesia.

Mamduh M. Hanafi dan Abdul Halim. 2003, Analisis Laporan Keuangan. Edisi Revisi, Unit Penerbit dan Percetakan AMP - YKPN.

Noor Achmad. 2007,.Analisa Laporan Keuangan, STIEK, Bogor

Simangunsong. 2004, Dasar - Dasar Akuntansi Keuangan, FEUI, Jakarta.

Soemarso. 2004, Revisi Akuntansi Suatu Pengantar. Edisi Kelima, PT. Salemba Emban Patria, Jakarta.

Sofyan Syafri Harahap. 2004, Analisis Kritis Atas Laporan Keuangan, PT. Raja Grafindo Persada, Jakarta.

Warren, Carl S., James M. Reeve and Philip E. Fess. 2005, Accounting, Thomson South - Western, United Kingdom.

Wild, John, J, K. R. Subramanyam, Robert F. Halsey. 2005, Financial Statement Analysis. 8th Edition, Salemba Empat, Jakarta.

Zaki Baridwan. 2004, Intermediate Accounting. Edisi 8, BPFE, Yogyakarta.

http ://sbinfocanada.about.com/cs/management/g/cashflowanal.htm

http://saham-bei.com/arus-kas-dari-aktivitas-operasi-investasi/fundamentalanalisis/2008/04/08 


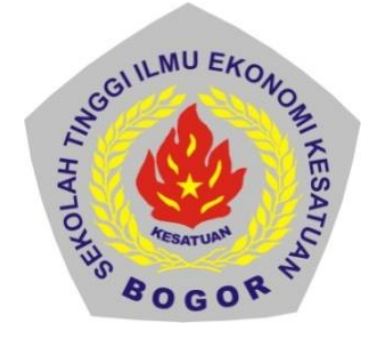

SIMPOSIUM MANAJEMEN

SEKOLAH TINGGI ILMU EKONOMI KESATUAN

BOGOR

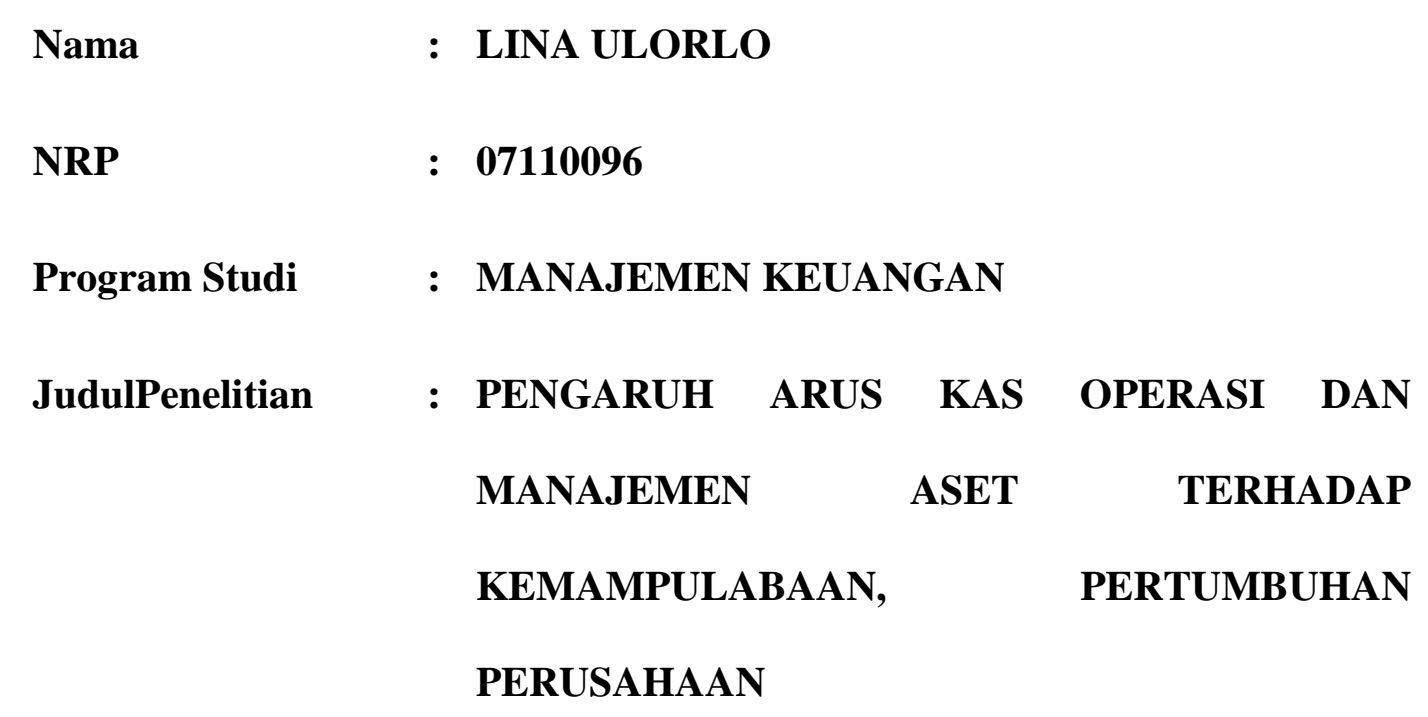

DosenPembimbing ： AAN SOELEHAN, SE., Ak,. MM.

Hari/Tanggal : SABTU, 21 JULI 2012

Waktu

: 09:00- SELESAI

Tempat

: KAMPUS STIE KESATUAN BOGOR 


\title{
PENGARUH ARUS KAS OPERASI DAN MANAJEMEN ASET \\ TERHADAP KEMAMPULABAAN, PERTUMBUHAN PERUSAHAAN
}

(Studi kasus pada PT Semen Gresik (Persero), Tbk dan PT Indocement

Tunggal Prakarsa, Tbk)

Oleh

\author{
Siti Sumarah Hati dan Muanas
}

\begin{abstract}
The study was conducted on PT.Semen Gresik Tbk (SGMR) which is a company that produces cement as well as PT Indocement Tunggal moving in the same field. The results of this study were, (a) the asset management SGMR is not used efficiently and in INTP can use with efficient asset management. (B) SGMR and INTP has a good profitability. (C) asset management SGMR no significant effect on profitability, asset management INTP has a significant effect on profitability. Asset management turnover is the faster it will influence on improving profitability. So the company can create the maximum profit the firm should use effective asset management and also be out of control eficient. The constrains factors like world commodity prices are always fluctuating, global crisis, the rules made by the government, competitors, etc. With make use of CATO, FATO SGMR profitability obtain the optimal level in 2011 and 2008, while the INTP in 2007 and 2008.
\end{abstract}

Keywords : Analysis influence on Asset Management

\section{PENDAHULUAN}

Perusahaan secara keseluruhan memiliki tujuan primer, yaitu menghasilkan laba, meningkatkan kesejahteraan, dan bertumbuh. Tujuan maksimalisasi laba biasanya dihubungkan dengan skala waktu jangka pendek, yaitu bagaimana mendaya gunakan kapasitas perusahaan yang tersedia saat ini seoptimal mungkin, diikuti dengan pengendaliaan biaya seefektif mungkin, sehingga laba yang dicapai adalah maksimal.

Tidak dapat diingkari bahwa tujuan menghasilkan laba adalah tujuan semua perusahaan. Bahkan kinerja manajemen selalu diukur dari kemampuan untuk memperoleh laba, agar tujuan perusahaan dapat tercipta dibutuhkan suatu sinergi antara divisi perusahaan, salah satunya yaitu dengan melakakukan pengelolaan manajemen aset perusahaan dengan baik. Manajemen aset adalah suatu potensi yang dimiliki oleh organisasi atau perseorangan untuk mencapai visi misi dan atau tujuan khususnya. Aset perusahaan terdiri dari aktiva lancar dan aktiva tetap. 
Bagi pemilik perusahaaan bahwa yang menjadi daya tarik utama bagi mereka adalah kemampulabaan. Kemampulabaan menggambarkan kemampuan perusahaan mendapatkan laba melalui semua kemampuan dan sumber yang ada dalam periode tertentu, seperti kegiatan penjualan, kas, modal, jumlah karyawan, jumlah cabang. Dalam hal ini kemampulabaan berarti hasil yang diperoleh melalui usaha manajemen terhadap pengelolaan manajemen asetnya.

Banyak cara atau tehnik dalam menganalisis manajemen aset salah satunya dengan menggunakan laporan keuangan dengan menggunakan alat bantu analisis rasio. Dengan menggunakan analiass rasio dapat membandingkan perusahaan yang satu dengan lainnya sehingga kita dapat melihat perkembangan perusahaan secara periodik .

\section{Perumusan Masalah}

Berdasarkan uraian diatas maka penulis merumuskan masalah sebagai berikut:

1. Bagaimana mengelola manajemen aset dengan efisien pada PT Semen Gresik (Persero) Tbkdan PT Indocement Tunggal Prakarsa Tbk?

2. Bagaimana kemapulabaan perusahaan PT Semen Gresik (Persero) Tbkdan PT Indocement Tunggal Prakarsa Tbk?

3. Bagaimana pengaruh manajemen aset terhadap kemampulabaan PT Semen Gresik (Persero) Tbkdan PT Indocement Tunggal Prakarsa Tbk?

\section{Maksud dan Tujuan Penelitian}

Penelitian yang dilakukan memiliki maksud untuk memperoleh data dan informasi serta gambaran secara jelas mengenai pengaruh manajemen asset terhadap kemampulabaan.

Adapun tujuan yang hendak dicapai penulis adalah sebagai berikut:

1. Untuk mengukur kemampuan perusahaan dalam mengelola aset perusahaan serta melakukan identifikasi mengenai pengaruh manajemen aset pada PT Semen Gresik (Persero) Tbkdan PTIndocement Tunggal Prakarsa Tbk.

2. Untuk mengetahui bagaiman kemampulabaan pada PT Semen Gresik (Persero) Tbkdan PTIndocement Tunggal Prakarsa Tbk.

3. Untuk mengetahui berapa besar pengaruh manajemen aset terhadap kemampulabaan pada PT Semen Gresik (Persero) Tbkdan PTIndocement Tunggal Prakarsa Tbk.

\section{TINJAUAN PUSTAKA}

\section{Manajemen Aset}

Setiap perusahaan umumnya menerapkan sistem manajemen aset,karena segala sesuatu yang terjadi di dalam perusahaan membutuhkan pengelolaan untuk mencegah penyimpangan - penyimpangan yang akan terjadi dan mengatasi penyimpangan yang sudah terjadi baik dalam kegiatan operasionalnya maupun non operasionalnya dengan melakukan feedback. Suatu manajemen proses secara global untuk membuat dan mengeksekusi nilai tertinggi tentang penggunaan dan perawatan asset secara konsisten(www.wordpress.com).

\section{Aktiva Lancar}


Aktiva yang masa perputarannya kurang atau maksimal dalam satu tahun. Termasuk dalam kelompok ini antaralain kas, efek, piutang dagang, piutang wesel, persediaan dan perlengkapan". Berdasarkan definisi diatas dapat disimpulkan bahwa aktiva lancar adalah kas dan aset aset lainnya yang ditukarkan menjadi kas (uang) dalam jangka wakyu 1( satu) tahun atau dalam1 ( satu ) periode kegiatan normal perusahaan (Sutrisno,2005)

\section{Aktiva Tetap}

Aktiva tetap menurut Sumarso (2005) adalah aktiva yang masa manfaatnya lebih dai satu tahun, digunakan dalam kegiatan oprasionalisasi perusahaan, dimiliki tidak untuk dijual kembali dalam kegiatan normal perusahaan,serta nilainya juga cukup besar. Tidak ada kriteria standar mengenai jangka waktu pemakaian minimal untuk membedakan aktiva tetap denga aktiva lainnya. Walau pun demikian,pemakaian lebih dari satu tahun pada umumnya digunakan sebagai pedoman. Kriteria lain adalah aktiva tersebut harus dipakai dalam kegiatan perusahaan dan tidak untuk di jual kembali. Aktiva yang dimiliki untuk dijual kembali dalam kegiatan normal perusahaan termasuk dalam kategori persediaan, walaupun aktiva tersebut jika dipakai dapat berumur lebih dari satu tahun .

\section{Kemampulabaan}

Menurut astuti (2004) profitabilitas adalah kemampuan suatu perusahaan untuk menghasilkan laba. (Sundjaja,2003) kemampuan perusahaan dalam menghasilkan laba biasanya dilihat dari hubungan antara pendapatan dengan biaya yang dihasilkan dari penggunaan aktiva perusahaan baik aktiva tetap maupun aktiva lancar dalam kegiatan yang produktif. Laba perusahaan data diikatkan melalui peningkatan pendapatan dan pengurangan biaya. Laba yang diperoleh perusahaan inilah yang akan meningkatkan dan mengembangkan usaha. Perusahaan akan dapat memperoleh keuntungan keuntungan lebih besar apabila perusahaan dapat memperluas pangsa pasar untuk produknya.

\section{Hasil Penelititian Terdahulu}

Tabel 1

Hasil penelitian terdahulu 


\begin{tabular}{|l|l|l|l|l|}
\hline NO & PENELITIAN & $\begin{array}{l}\text { VARIABEL } \\
\text { PENELITIAN }\end{array}$ & ANALISIS & HASIL \\
\hline 1 & $\begin{array}{l}\text { Faurani Santi } \\
\text { Singagenda } \\
\text { (2004) }\end{array}$ & $\begin{array}{l}\text { Modal Kerja,tingkat } \\
\text { profitabilitas,tingkat } \\
\text { rentabilitas }\end{array}$ & $\begin{array}{l}\text { Analisis } \\
\text { korelasi }\end{array}$ & $\begin{array}{l}\text { Modal kerja } \\
\text { berpengaruh } \\
\text { positif } \\
\text { terhadap } \\
\text { profitabilitas } \\
\text { dan } \\
\text { rentabilitas }\end{array}$ \\
\hline 2 & $\begin{array}{l}\text { Debora Setiati } \\
\text { Santosa }\end{array}$ & $\begin{array}{l}\text { Aktiva lancar,total } \\
\text { aktiva, debt to } \\
\text { equity ratio, ROE }\end{array}$ & $\begin{array}{l}\text { Analisis } \\
\text { regresi } \\
\text { berganda } \\
\text { berpengaruh } \\
\text { positif } \\
\text { terhadap roe, } \\
\text { sedangkan } \\
\text { aktifa lancar } \\
\text { dan debt to } \\
\text { equity rasio } \\
\text { tidak } \\
\text { berpengaruh. }\end{array}$ \\
\hline
\end{tabular}

Perbedaan penelitian ini dengan penelitiaan- penelitian sebelumnya adalah

1. Penelitian ini berbeda dengan penelitian sebelumnya dalam periode waktu yang digunakan. Penelitian ini menggunakan periode waktu 2007 sampai dengan 2011

2. Variabel yang digunakan dalam penelitian ini berbeda dengan penelitian sebelumnya. Variabel penelitian ini adalah current aset turnover, fixed aset turnover, gross profit margin, operating profit margin.

\section{Kerangka Pemikiran}

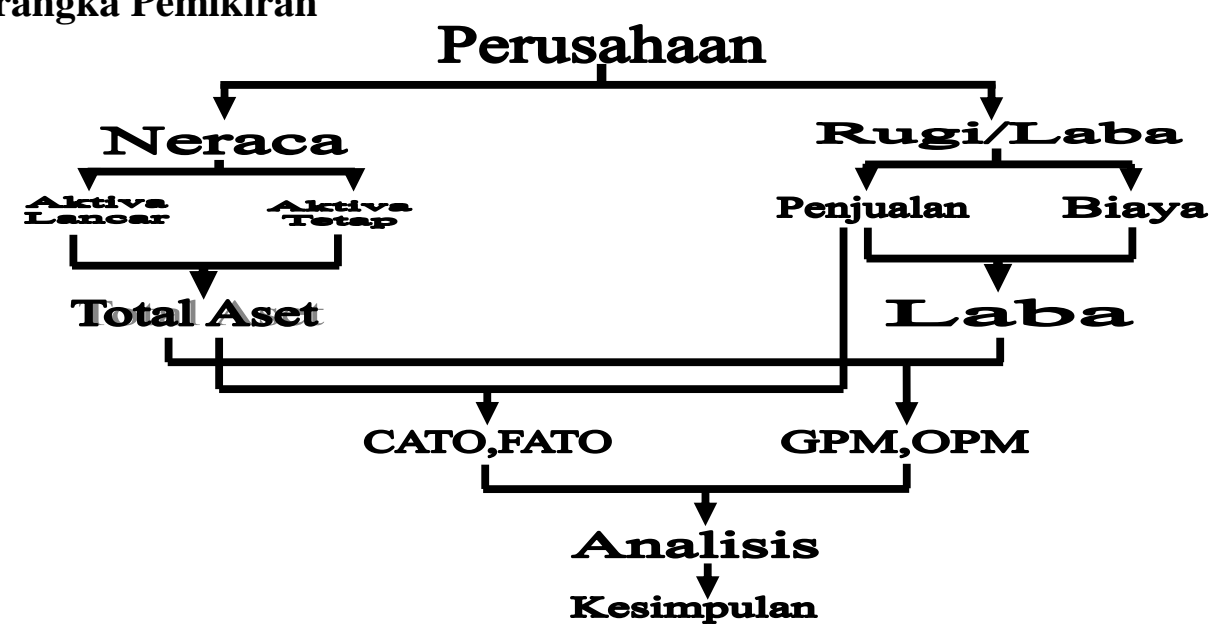

Gambar 1

Kerangka Pemikiran Konseptual

Setelah dilakukan pemahaman mengenai variable-variabel penelitian,yakni manajemen aset dan kemampulabaan selanjutnya penulis mengunakan metode analisis . Apabila sudah dilakukan analisis dari setiap variable penelitianya maka selanjutnya penulis akan mengukur dan menilai kinerja perusahaan untuk 
mengetahui tolak ukur dan menilai kondisi perusahaan dengan metode analisis tersebut. Apabila sudah diketahui hasil penelitian , maka selanjutnya penulis akan membuat suatu kesimpulan yang nantinya akan dijadikan sebagai dasar untuk memberikan suatu rekomendasi atau saran bagi pihak-pihak yang berkepentingan didalamnya, dengan harapan rekomendasi atau saran dapat bermanfaat bagi pihakpihak tersebut.

\section{Hipotesis Penelitian} berikut:

Berdasarkan kerangka berpikir di atas maka dibuat hipotesis sebagai

1. Diduga perusahaan mampu mengelola manajemen aset secara efisen

2. Diduga perusahaan dapat menciptakan kemampulabaan yang maksimal

3. Diduga manajemen aset berpengaruh positif terhadap kemampulabaan

\section{Metodologi Penelitian}

Penelitian yang digunakan adalah metode deskriptif komparatif, yaitu suatu metode yang dilakukan dengan cara mencari data yang dapat memberikan gambaran yang jelas tentang PT. Semen Gresik, Tbk dan PT. Indocement Tunggal Prakarsa,Tbk. Kemudian penulis bermaksud untuk membandingkan perkembangan peningkatan kemampulabaan dan pertumbuhan perusahaan tiap tahun dalam periode 5 tahun terakhir.

Penelitian ini menggunakan data sekunder. Data sekunder adalah data yang ditrerbitkan atau digunakan oleh orang atau organisasi yang bukan pengelolanya. Data sekunder dari penelitian ini adalah data yang diperoleh dari lembaga Bursa Efek Indonesia dengan membeli data perusahaan di Pojok BEI yang berada di STIE Kesatuan serta penulis melakukan studi kepustakaan.

\section{Operasional Variabel}

Tabel 2

Operasional Variabel

\begin{tabular}{|c|c|c|c|}
\hline Variabel & Fungsi & Indikator & Skala/Ukuran \\
\hline \multirow{2}{*}{ Manajemen aset } & $\mathrm{X}_{1}$ & CATO & Rasio \\
& $\mathrm{X}_{2}$ & FATO & Rasio \\
\hline \multirow{2}{*}{ Kemampulabaan } & $\mathrm{Y}_{1}$ & OPM & Rasio \\
& $\mathrm{Y}_{2}$ & GPM & Rasio \\
\hline
\end{tabular}

\section{Pengolahan dan Analisis Data}

Teknik yang digunakan dalam menganalisis manajemen aset terhadap kemampulabaan perusahaan dengan menggunakan data yang akan diperoleh di dalam laporan keuangan pada perusahaan yang akan diteliti. Dari laporan keuangan akan dianalisis dengan menggunakan rasio current aset turnover, rasio fixed aset turnover, rasio gros profit margin, rasio operating profit margin.

Selain dengan analisis digunakan juga analisis Koefesien Korelasi,Metode ini digunakan untuk mengetahui tingkat keeratan hubungan antara 2 variabel, yaitu manajemen aset dan kemampulabaan dengan menggunakan rumus koefesien korelasi,dan analisis regresi linier sederhana metode ini untuk melihat kejelasan 
seberapa besar pengaruh variabel bebas (cato, fato) terhadap variabel terikat (Gpm,Opm), maka penulis menggunakan analisis regresi linear sederhana.

\section{Hasil dan Pembahasan}

1. Manajemen Aset (CATO, FATO) PT. Semen Gresik (Persero), Tbk

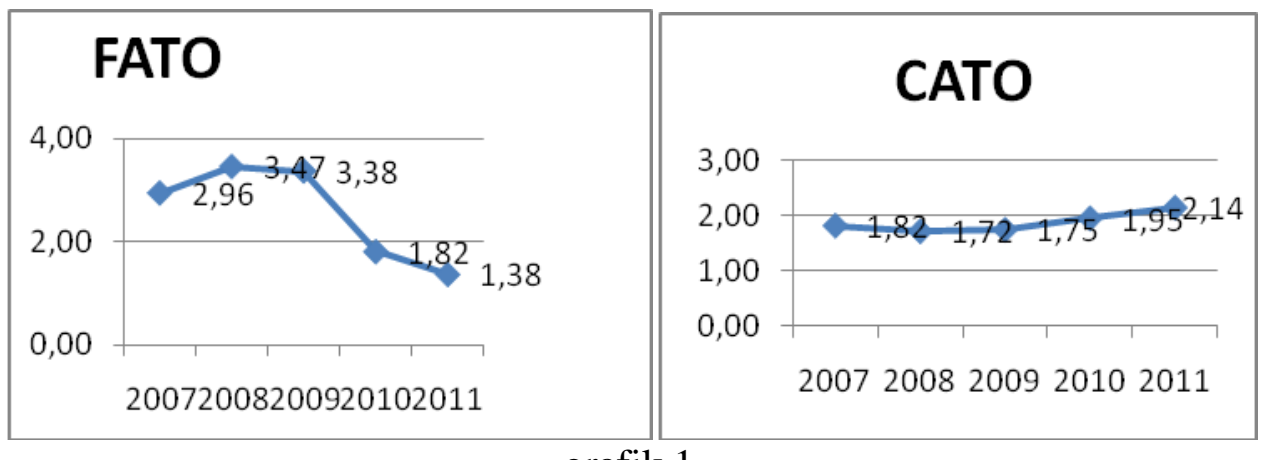

grafik 1

Pergerakan FATO dan CATO PT Semen Gresik (Persero), Tbk

PT. Semen Gresik (Persero), Tbk mempunyai aktiva tetap atau fato yang tidak efisien. Hal ini dapat dilihat dari grafik diatas yang menunjukan turunnya fato disebabkan karena terjadinya gempa di Sumatra yang mengakibatkan aktifa tetap anak perusahaan rusak. PT. Semen Gresik (Persero) Tbk menghasilkan cato yang efisien sehingga mengalami peningkatan dari tahun ketahun meskipin tahun 2008 mengalami penurunan.

Manajemen Aset (CATO, FATO) PT. Indocement Tunggal Prakarsa Tbk

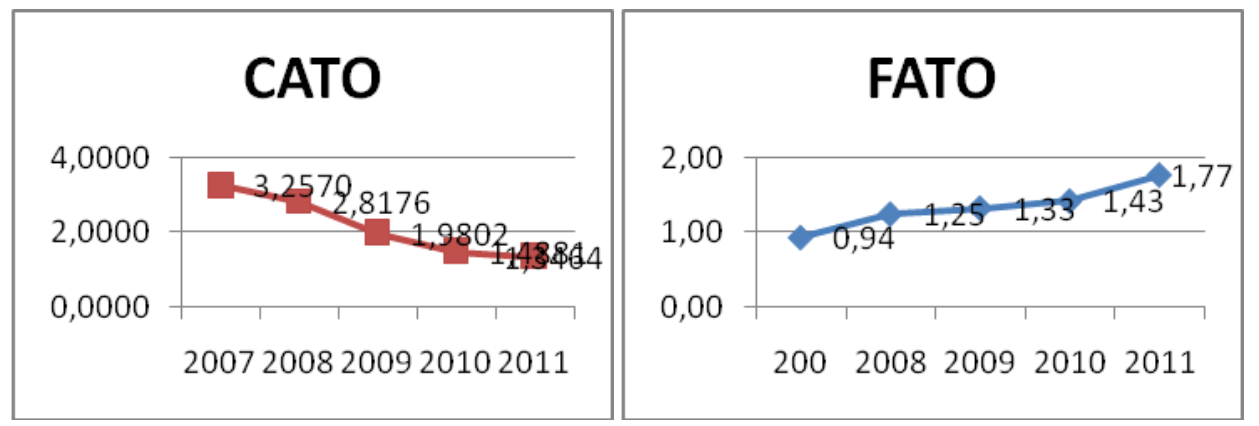

Grafik 2

Pergerakan CATO dan FATO PT.Indocement Tunggal Prakarsa Tbk

Currunt asset turnover PT. Indocement Tunggal Perkasa dari tahun 20072011 selalu mengalami penurunan dari tahun ke tahun. Penurunan current asset tersebut disebabkan karena perusahaan selalu menambah kas dan setara kas yang artinya perusahaan mengalami penumpukan harta karena perusahaan tidak menggunakan aktiva lancar dengan efisien sehingga perusahaan tidak dapat mencapai penjualan yang semaksimal mungkin. Fixed asset turnover pada PT. Indocement mempunyai peningkatan dari tahun 2007 sampai dengan 2011. Ini dapat membuktikan baiknya kinerja manajemen dalam menggelola aktiva tetap. 


\section{Kemampulabaan (GPM , OPM) PT.Semen Gresik (Persero) Tbk}

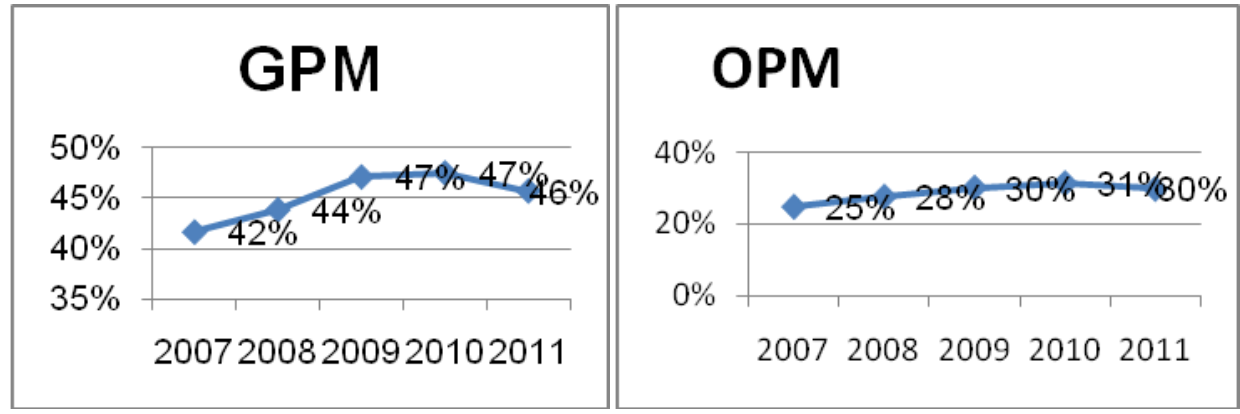

Grafik 3

Pergerakan GPM dan OPM PT. Semen Gresik (Persero) Tbk

GPM PT Semen Gresik Tbk mengalami penigkatan dari tahun 2007-2010 akan tetapi pada tahun 2011 mengalami penurunan. Dapat disimpulkan bahwa PT Semen Gresik (Persero), Tbk mampu meningkatkan penjualan untuk menghasilkan laba perusahaan. PT Semen Gresik (Persero) Tbk menghasilan operating profit margin yang mingkat dari tahun ke tahun. Hal ini disebabkan karena PT. Semen Gresik (Persero), Tbk pada periode 2007-2011 mampu meningkatkan penjualan untuk menghasilkan laba.

\section{Kemampulabaan (GPM, OPM) PT Indocement Tunggal Prakarsa, Tbk}

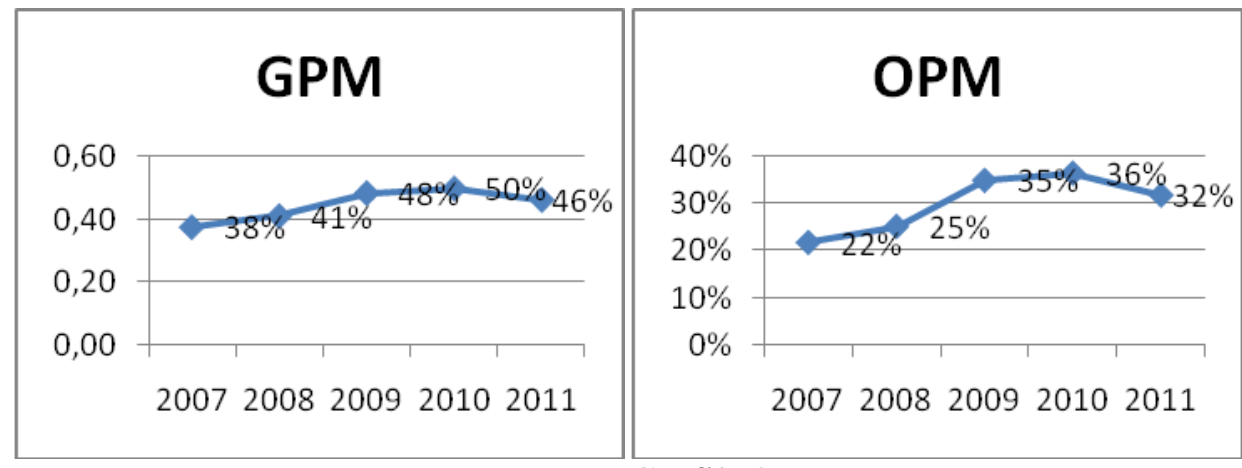

Grafik 4

Pergerakan GPM dan OPM PT Indocement Tunggal Prakarsa Tbk

PT Indocement Tunggal Prakarsa Tbk menghasilkan gros profit margin yang meningkat dari tahun ketahun meningkat. Hal ini disebabkan karena naiknya laba kotor dan penjualan dari tahun ketahun. PT Indocement Tunggal Prakarsa Tbk menghasilkan operating profit margin yang meningkat dari tahun ketahun. Hal ini disebabkan perusahaan mampu meningkatkan laba kotor. Ini membuktikan perusahaan mampu menciptakan kemampulabaan yang maksimal.

\section{Pengaruh manajemen asset terhadap kemampulabaan.}

Pengolahan atas data yang digunakan dalam penelitian ini memberikan hasil seperti tabel-tabel berikut:

Tabel 2: Hubungan manajemen asset (CATO,FATO) terhadap kemampulabaan (GPM)

\begin{tabular}{|l|l|l|l|l|}
\hline Perusahaan & r & R & F & Sig \\
\hline SGMR & 0,796 & 0,633 & 1,726 & 0,367 \\
\hline INTP & 0,955 & 0,913 & 10,441 & 0,087 \\
\hline
\end{tabular}


Tabel 3: pengaruh manajemen asset (CATO,FATO) terhadap kemapulabaan (GPM)

\begin{tabular}{|l|l|l|l|l|l|l|l|}
\hline Perusahaan & a & B1 & B2 & T1 & T2 & Sig 1 & Sig 2 \\
\hline SMGR & 1,228 & $-0,319$ & $-0,071$ & $-1,483$ & $-1,736$ & 0,276 & 0,225 \\
\hline INTP & 0,805 & $-0,093$ & $-0,711$ & 3,217 & 0,117 & 0,85 & 0,281 \\
\hline
\end{tabular}

Pada tabel 2 kasus SMGR, Nampak bahwa $r$ dan $r$ kedua variabel di atas masingmasing dalam kategori kuat. Akan tetapi dengan alpha sebesar 36,7 \%dapat dikatan bahwa secara sistematis hubungan variabel tersebut tidak nyata. Keadaaan sangat berlawanaan pada kasus INTP hubunga antara variabel justru terlihat nyata(alpa $8,7 \%<10 \%$ ). Selanjutnya pada tabel 3 secara simultan cato dan fato tidak terlalu berpengaruh terhadap gpm. Pada SMGR peranan aktiva tetap lebih dominan dan pada kasus INTP peranan aktiva lancar lebih dominan dalam penetapan pertumbuhan laba. Pada uji $r$ pengaruh cato dan fato kasus SMGR $(0,633)$ dan tidak signifikan $(36,7 \%)$ sementara INTP tinggi $(0,913)$ dan signifikan $(8,7 \%)$.

Tabel 4: hubungan manajemen asset (CATO,FATO) terhadap kemampulabaan (OPM)

\begin{tabular}{|l|l|l|l|l|}
\hline perusahaan & R & R2 & F & Sig \\
\hline SMGR & 0,798 & 0,636 & 1,749 & 0,364 \\
\hline INTP & 0,960 & 0,921 & 11,72 & 0,071 \\
\hline
\end{tabular}

Tabel 5 : pengaruh manajemen asset (CATO,FATO) terhadap kemampulabaan (OPM)

\begin{tabular}{|l|l|l|l|l|l|l|l|}
\hline perusahaan & a & B1 & B2 & T1 & T2 & Sig 1 & Sig 2 \\
\hline SMGR & 1,020 & 0,296 & 0,070 & 1,313 & 1,633 & 0,032 & 0,244 \\
\hline INTP & 0,788 & 0,122 & 0,166 & 3,550 & 1,741 & 0,071 & 0,224 \\
\hline
\end{tabular}

Pada tabel 4 kasus SMGR, Nampak bahwa $\mathrm{r}$ dan r2 variabel diatas masingmasing dalam kategori kuat. Akan tetapi dengan alpha sebesar 36,4\% dapat dikatakan bahwa secara sistematis hubungan variabel tersebut tidaknyata karena tidak signifikan $(10 \%<36,4 \%)$. Keadaan berlawanan pada kasus INTP hubungan antara variabel justru nyata yaitu nilai signifikan sebesar 7,1\% (alpha 7,1\%<10\%). Selanjutnya pada tabel 5 secara simultan cato dan fato berpengaruh terhadap opm. Pada SMGR peranan aktiva lancar lebih dominan dan pada kasus INTP aktiva tetap lebih dominan.

\section{Hasil Hipotesis}

1. Mampu mengelola manajemen asset diterima

2. Mampu menghasilkan Kemampulabaan yang maximal diterima

3. Pengaruh Manajemen Aset terhadap Kemampulabaan PT Semen Gresik (Persero) Tbk

a. GPM, Ho di terima dan Ha di tolak

b. OPM, Ho di terima dan Ha di tolak

PT Indocement Tunggal Prakarsa Tbk

a. GPM, Ho di tolak dan Ha diterima

b. FATO, Ho di tolak dan Ha di terima 


\section{Kesimpulan dan Saran}

\section{Kesimpulan}

Berdasarkan pengamatan dan penelitian yang dilakukan oleh penulis mengenai Analisis Pengaruh manajemen aset terhadap kemampulabaan periode 2007-2011) serta pengolahan data dengan menggunakan Software Statistic Microsoft 18.0, maka penulis mengambil kesimpulan pokok dari data yang diteliti yaitu antara lain:

1. Pengelolaan manajemen aset yang efisien dapat meningkatkan kemampulabaan perusahaan.

2. Penelitian ini membuktikan bahwa manajemen aset terhadap kemempulabaan (GPM dan OPM) memiliki hubungan dan pengaruh yang signifikan. Dari hasil penelitian yang dilakukan diperoleh nilai koefisien korelasi ada PT Semen Gresik (Persero) Tbk . Nilai R sebesar 79,6\% dan 7,98\%. Hal ini menunjukan bahwa terdapat hubungan yang kuat antara. Manajemen aset dengan kemampulabaan. Sedangkan hasil koefisien determinasi (R2) sebesar 63,3\% dan $63,6 \%$, menunjukan bahwa $36,7 \%$ dan 36,6\% kemampulabaan dipengaruhi oleh manajemen aset.Penelitian ini membuktikan bahwa manajemen aset terhadap kemempulabaan (GPM dan OPM) memiliki hubungan dan pengaruh yang signifikan. Dari hasil penelitian yang dilakukan diperoleh nilai koefisien korelasi ada PT Indocemen Tunggal Prakarsa. nilai R sebesar 95,5\% dan 96\%. Hal ini menunjukan bahwa terdapat hubungan yang kuat antara. Manajemen aset dengan kemampulabaan. Sedangkan hasilkoefisien determinasi (R2) sebesar 91,3\% dan 91,2\%, menunjukan bahwa $8,7 \%$ dan38,8\%kemampulabaan dipengaruhi oleh manajemen aset.

\section{Saran}

1. Untuk meningkatkan kas bersih dari aktivitas operasi perusahaan harus melakukan efisiensi pada biaya - biaya dan dapat meningkatkan penjualan produk semennya. Perusahaan yang bergerak pada industri semen mempunyai masa depan yang cukup bagus, karena Indonesia sedang dalam tahap pembangunan. Dengan hal tersebut diharapkan perusahaan yang bergerak didalam industri semen dapat memanfatkan hal ini untuk meningkatkan pertumbuhan penjualan mereka dan meningkatkan laba dengan melakukan efisiensi.

\section{Daftar Pustaka}

Ahcmad, Noor. 2007. Analisis Laporan Keuangan. STIE Kesatuan. Bogor Agus Sartono. 2001. Manajemen Keuangan Teori dan Aplikasi BPFE. Yogyakarta Astuti, Dewi,MM. 2004. Manajemen Keuangan Perusahaan. Ghalia. Jakarta

Block, Stanley B, and Geoffrey A Hirt. 2005. Foundations of Financial Manajemen.Third Edition,Ohio: South Western

Bringham, Eugene. F dan Houston, Joel. F. 2000. Manajemen Keuangan ,Buku I. Erlangga. Jakarta

Bringham,Eugene. F dan Houston,Joel. F. 2007. Manajemen Keuangan, Alih bahasa:Herman Wibiwo, Erlangga. Jakarta 
Hanafi dan Abdul halim. 2001. Analisis Laporan Keuangan . AMP. YKPN, Yogyakarta

Horne James C.Van dan Jhon M. W. Jr .1997. Prinsip-prinsip Manajemen Keuangan. selemba Empat, Jakarta

Harahap, Sofyan Syafri. 20010 Analisis Kritis atas Laporan Keuangan. cetakan keempat. PT. Raja Grafindo Persada,Jakarta

Munawir. 2004. Analisis Laporan Keuangan. Liberty. Yogyakarta

Ridwan S. Sundjaja., dan Inge Barlian. 2003. Manajemen Keuangan.Literata Lintas Media, Jakarta.

Rianto, Bambang. 1995. Dasar-dasar Pembelajaran Perusahaan. Edisi 4, BPEE Yogyakarta, Yogyakarta.

Sartono,R. Agus. 2001. Manajemen Keuangan Teori dan Aplikasi. Edisi4, Yogyakarta.

Sawir,Agnes. 2005. Buku Panduan Direktur Keuangan.Edisi kedua, Selemba Empat. Jakarta

Suad, Husnan dan Enny Pudjiastuti. 2004. Dasar-dasar Manajemen Keuangan, UPP (Unit Penerbit dan Pencetak) AMP, YKPM, Yogyakarta

Setiawan, H. and Edison, E., 2008. Penerapan perhitungan harga pokok produksi dalam kaitannya dengan pelaporan keuangan pada PT Alas Seni Kreasi Industri. Jurnal Ilmiah Kesatuan (JIK), 10(1), pp.20-25.

Nurjanah, Y. and Supardji, S., 2008. Evaluasi Atas Sistem Dan Prosedur Produksi Dalam Kaitannya Dengan Persediaan Barangjadi Studi Kasus Pada PT. Cahaya Buana Intitama. Jurnal Ilmiah Kesatuan (JIK), 10(1), pp.61-67.

Triandi, T. and Prabowo, A., 2008. Penerapan Data Base Persediaan Dan Data Pasien Berbasis Microsoft Access Dalam Rangka Meningkatkan Efisiensi Operasi Pada Puskesmas Sukaharja. Jurnal Ilmiah Kesatuan (JIK), 10(1), pp.47-54.

Muanas, M. and Wijayantri, A.C., 2010. Evaluasi Atas Penerapan Sistem Online Payment Point Pos (SOPPOS) Dalam Kaitannya Dengan Efisiensi Kegiatan Operasional Pada PT Pos Indonesia (Persero). Jurnal Ilmiah Ranggagading (JIR), 10(1), pp.28-31.

Rosa, E.S. and Suharmiati, S., 2008. Peranan Sistem Pengendalian Persediaan Bahan Baku Dalam Menunjang Efektivitas Proses Produksi Studi Kasus Pada PT. Super Glossindo Indah. Jurnal Ilmiah Kesatuan (JIK), 10(1), pp.41-45.

Sujana, S., Zuhdi, S. and Purwitayani, P., 2006. Teknik Analisis Forward Contract Hedging dengan Money Market Hedging dalam Meminimalisasi Tingkat Risiko Kerugian: Studi Kasus pada PT. Elang Perdana Tyre Industry. Jurnal Ilmiah Ranggagading (JIR), 6(1), pp.36-40.

Cahyani, N. and Morita, M., 2009. Perbedaan Pengakuan Pendapatan Pada Bank Syariah Dan Bank Konvensional. Jurnal Ilmiah Kesatuan (JIK), 11(1).

Effendy, M., Surya, T.M. and Mubarak, M.M., 2009. Pengaruh Struktur Modal Terhadap Resiko Keuangan Perusahaan. Jurnal Ilmiah Kesatuan (JIK), 11(1).

Hasibuan, D.H., Marpaung, A.M. and Gunawan, Y., 2011. Evaluasi Atas Pengakuan Pendapatan Pada Perusahaan Jasa Konstruksi Kaitannya Terhadap Laporan Laba Rugi Perusahaan. Jurnal Ilmiah Ranggagading (JIR), 11(2), pp.142-149. 
Pardede, R.P. and Siallagan, E., 2007. Analisis Portofolio Optimum Saham Ditinjau Dari Expected Return Dan Risk Penalty Berdasarkan Model Markowitz Studi Kasus Pada Industri Telekomunikasi. Jurnal Ilmiah Kesatuan (JIK), 9(2). 